
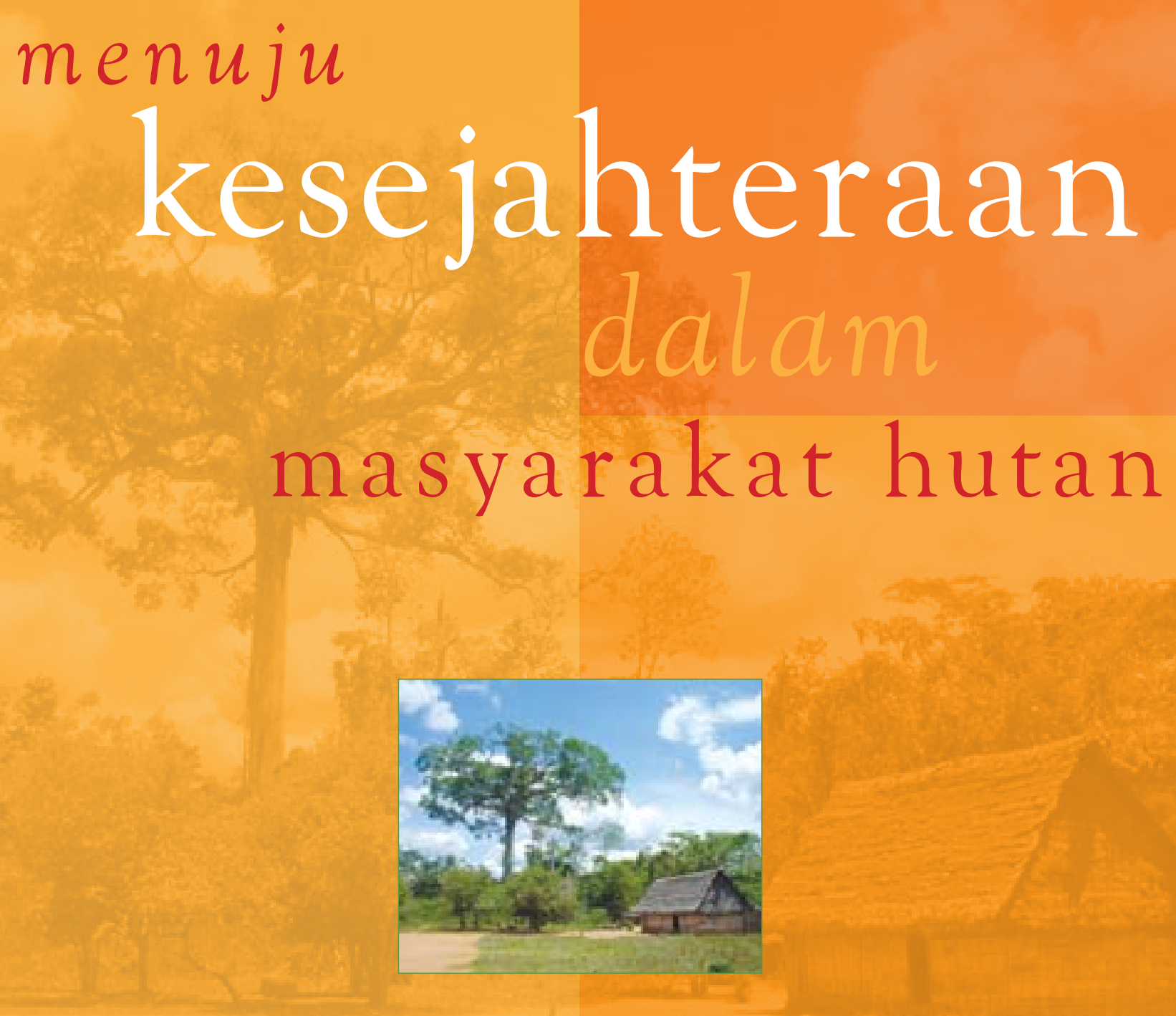



$$
\begin{aligned}
& \text { menuju } \\
& \text { kesejahteraan } \\
& \text { masyarakat hutan }
\end{aligned}
$$


(c) 2007 Center for International Forestry Research (CIFOR)

Semua hak dilindungi undang-undang. Dilarang memperbanyak, menyimpan dalam sistem retrieval, atau menyebarkan bagian mana pun dari dokumen ini dalam bentuk atau alat apa pun (elektronik, mekanis, fotokopi, rekaman atau lainnya), tanpa izin sebelumnya dari penerbit.

Diharuskan mengutip dengan benar:

Center for International Forestry Research (CIFOR) 2007. Menuju kesejahteraan dalam masyarakat hutan: Buku Panduan untuk Pemerintah Daerah. CIFOR, Bogor, Indonesia. 98 hal.

ISBN: 978-979-1412-32-2

Kata kunci: Kemiskinan, kesejahteraan, pemerintah daerah, desentralisasi, hutan, masyarakat, pembangunan pedesaan, pemantauan, skenario, GIS, pemetaan, indikator

Publikasi ini adalah hasil kerjasama para peneliti di bawah ini (urut abjad):

\author{
Marco Antonio Albornoz \\ Michel Becker \\ Ade Cahyat \\ Peter Cronkleton \\ Wil de Jong \\ Kristen Evans \\ Dante Fuentes \\ Christian Gönner \\ Rolando Haches \\ Michaela Haug \\ Ramses Iwan \\ Godwin Limberg \\ Moira Moeliono \\ Eva Wollenberg
}

\section{Lembaga mitra:}

Center for Integrated Area Studies (CIAS), Kyoto University, Jepang

Bundesministerium für Wirtschaftliche

Zusammenarbeit und Entwicklung (BMZ), Jerman University of Freiburg, Jerman

The Swiss Agency for Development Cooperation, Swiss Pemerintah Kabupaten Kutai Barat, Indonesia Pemerintah Kabupaten Malinau, Indonesia Pemerintah Daerah El Sena, Bolivia

Bundesministerium für Wirtschaftliche

Zusammenarbeit und Entwicklung (BMZ), Jerman yang menyediakan dana untuk penelitian dan pengembangan publikasi ini.

Penterjemah: Sugeng Hariyanto

Editor: Tiene Gunawan

Desain dan tata letak oleh Kristen Evans, Gideon Suharyanto dan Vidya Fitrian

Diterbitkan oleh

Center for International Forestry Research

Alamat pos: P.O. Box 0113

BOCBD, Bogor 16000, Indonesia

Alamat kantor: Jl. CIFOR, Situ Gede,

Bogor Barat 16115, Indonesia

Tel: +62 (251) 622622; Fax: +62 (251) 622100

Email: cifor@cgiar.org

Website: http://www.cifor.cgiar.org 


\section{Daftar Isi}

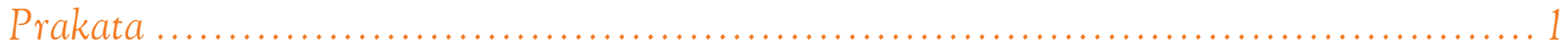

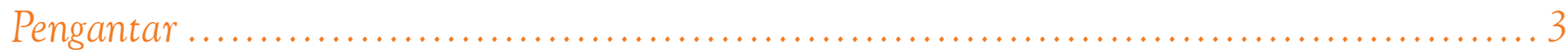

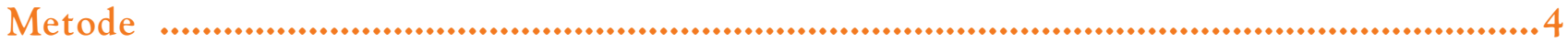

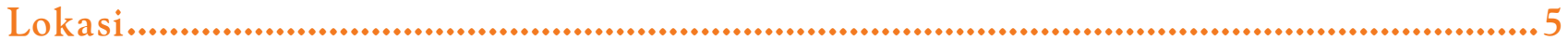

Mengapa Pando dan Kalimantan Timur?................................................................ 5

Pemerintah kota dan desentralisasi di Bolivia ........................................................... 6

Pemerintah kabupaten dan desentralisasi di Indonesia ................................................ 7

Bagian I. Konsep . . . . . . . . . . . . . . . . . . . . . . . . . . . . . . . . . . . . . . . . . . . . . . . . . . 9

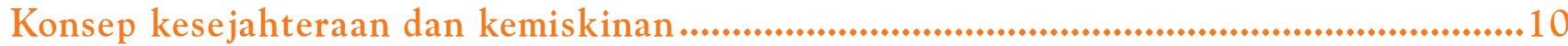

Kemiskinan adalah kurangnya kesejahteraan ..................................................... 10

Kemiskinan lebih dari sekedar rendahnya pendapatan .............................................. 10

Kemiskinan dan kesejahteraan memiliki banyak dimensi .............................................. 11

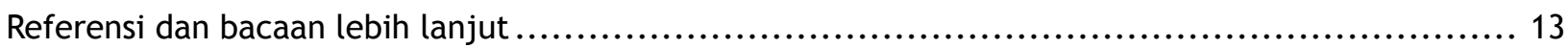

Bagaimana pemerintah daerah dapat mempengaruhi kemiskinan? ........................... 15

Apa yang dapat dilakukan pemerintah daerah? ................................................. 15

Empat langkah untuk meningkatkan tindakan pemerintah daerah ................................... 18

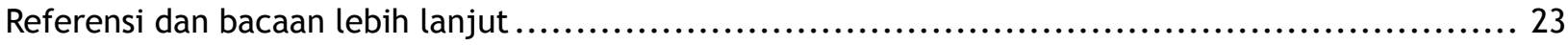

Bagaimana hutan mempengaruhi kesejahteraan? ..................................................... 24

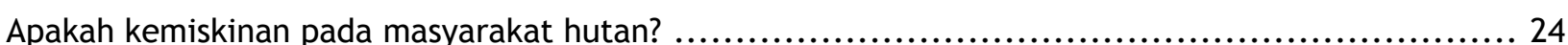

Apakah hutan merupakan jaring pengaman, jebakan kemiskinan atau jalan keluar? ................... 27

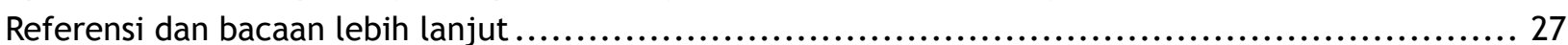




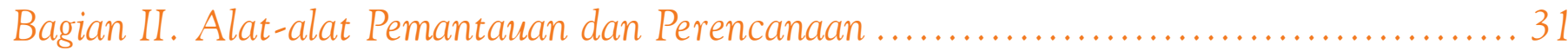

Mendukung siklus pengambilan keputusan pemerintah daerah.......................................32

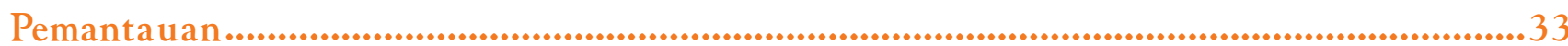

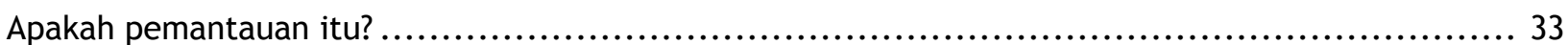

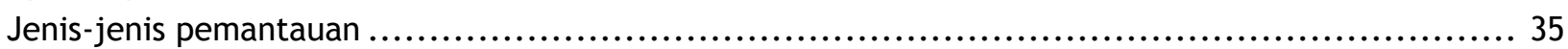

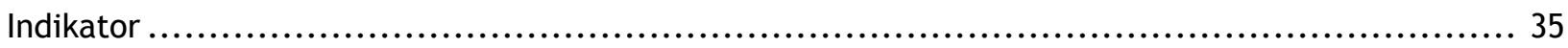

Kapan melakukan pemantauan?............................................................... 36

Siapa yang melakukan pemantauan? ......................................................... 36

Menghubungkan pemantauan dengan perencanaan.......................................... 37

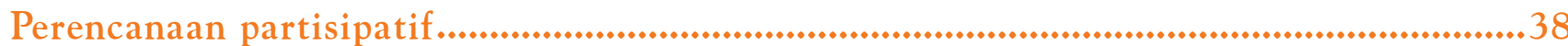

Apakah perencanaan partisipatif itu? .......................................................... 38

Mengapa perencanaan partisipatif perlu? ....................................................... 38

Kapan dan di mana perencanaan partisipatif dilakukan? ....................................... 39

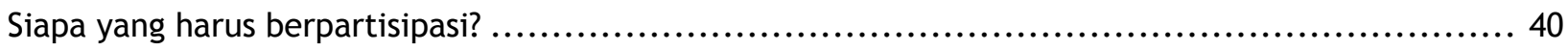

Alat 1: Memantau konteks kemiskinan lokal melalui pemetaan interaktif ...................42

Apakah pemetaan interaktif itu?............................................................ 42

Mengapa pemetaan interaktif perlu?........................................................... 43

Cara melakukan pemetaan interaktif: Langkah demi langkah ..................................... 44

Menggunakan pemetaan interaktif untuk pemantauan........................................ 50

Alat 2: Memantau kesejahteraan rumah tangga melalui survei berdasarkan indikator lokal ....... 51

Apakah sistem pemantauan kesejahteraan lokal itu?........................................... 51

Mengapa sistem pemantauan kesejahteraan lokal perlu?......................................... 51

Cara menggunakan sistem pemantauan kesejahteraan lokal..................................... 52

Alat 3: Mengevaluasi program pemerintah daerah melalui kelompok fokus masyarakat ..............70

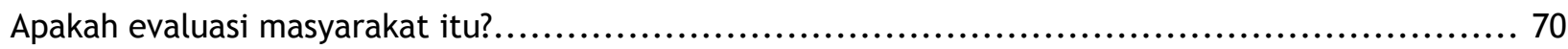

Mengapa evaluasi masyarakat diperlukan? ...................................................... 71

Cara melakukan evaluasi masyarakat: Langkah demi langkah ................................... 73

Alat 4: Menyampaikan kebutuhan masyarakat melalui perencanaan berbasis skenario ..............83 83

Apakah perencanaan berbasis skenario itu?................................................. 83

Mengapa perencanaan berbasis skenario perlu? ........................................... 83

Cara menggunakan skenario perencanaan: Langkah demi langkah............................... 85

Pembentukan Visi ......................................................................... 86

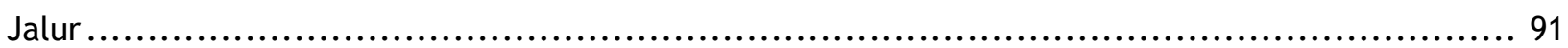

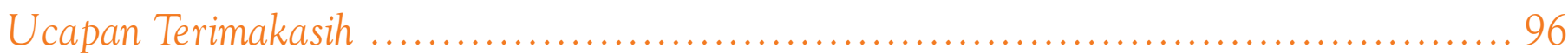

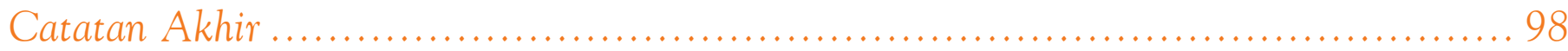




\section{Prakata}

Terdapat potensi yang sangat besar untuk meningkatkan kesejahteraan masyarakat hutan, yang sejauh ini masih tergolong dalam kelompok masyarakat paling miskin di dunia. Untuk mengelola potensi ini, peran penting berada di tangan pemerintah daerah. Di negara-negara berkembang, berkat desentralisasi, pemerintah daerah memiliki kewenangan baru untuk mengambil keputusan dan tanggung jawab untuk memberikan layananlayanan, termasuk menanggulangi kemiskinan.

Tetapi pemerintah daerah sering tidak memiliki data dan informasi yang cukup untuk mengidentifikasi penyebab kemiskinan, memprioritaskan tindakan atau membidik kelompok miskin tertentu. Pemerintah daerah, yang di masa lalu sering diabaikan karena sistem perencanaan yang sentralistis, tidak memiliki cukup pengalaman dalam menyiapkan dan menerapkan rencana pembangunan daerah. Kondisi ini diperumit dengan tidak memadainya kewenangan, mandat dan sumber daya yang dialihkan ke daerah atau koordinasi antar-sektor yang lemah. Terbatasnya akuntabilitas ke bawah membatasi kemauan politik pemerintah daerah yang baru diberdayakan untuk bertindak.

Para pembuat kebijakan dan praktisi pembangunan telah meningkatkan perhatian mereka dalam penanggulangan kemiskinan dan bergelut dengan pertanyaan penting tentang bagaimana sebaiknya kemiskinan diukur dan dipantau. Di masa lalu, tingkat kemiskinan ditentukan berdasarkan proporsi individu atau rumah tangga yang tidak mampu memenuhi standar pendapatan atau gizi minimum. Kemiskinan diukur berdasarkan indikator-indikator nasional. Saat ini, pendekatan pengukuran kemiskinan yang lebih holistik mulai mengemuka. Meski demikian, indikator kemiskinan dan kesejahteraan yang relevan di tingkat daerah secara umum masih belum ada.

Menuju Kesejahteraan dalam Masyarakat Hutan: Buku Panduan untuk Pemerintah Daerah ini menawarkan konsep baru yang menyegarkan dalam memandang kesejahteraan yang berkelanjutan, yang melebihi kriteria kecukupan penghasilan dan pangan. Para penulis menggunakan pengalamannya di Bolivia dan Indonesia untuk mengedepankan pendekatan dalam mengembangkan pemantauan kemiskinan dan tindakan yang relevan dengan kondisi daerah. Buku panduan ini tentunya akan menjadi sumber daya yang berguna bagi pemerintah daerah yang berkepentingan dalam menanggulangi kemiskinan melalui pendekatan yang lebih partisipatif bersama masyarakat setempat. Peran potensial hutan dalam meningkatkan kesejahteraan masyarakat juga mendapat penekanan khusus dalam buku ini.

Bagian I menyajikan tinjauan konseptual kemiskinan dan kesejahteraan dengan menggunakan perspektif yang dinamis dan multi-aspek. Bagian ini juga memuat analisis tentang tindakan yang dapat diambil pemerintah daerah untuk menanggulangi kemiskinan, baik secara langsung maupun melalui advokasi tingkat pemerintah yang lebih tinggi atau badan-badan sektoral. Selain itu, pada bagian ini diuraikan pula faktor-faktor yang relevan dalam menjawab tantangan penanggulangan kemiskinan pada masyarakat hutan.

Bagian II menguraikan empat alat praktis untuk membantu pemerintah daerah meningkatkan rancangan dan implementasi program penanggulangan kemiskinan. Keempat alat tersebut adalah pemetaan konteks kemiskinan secara interaktif, survei kesejahteraan rumah tangga berdasarkan indikator daerah, kelompok-kelompok fokus masyarakat untuk mengevaluasi program-program pemerintah, dan perencanaan berbasis skenario. Keempatnya dirancang untuk menjembatani kekurangan informasi dan kemampuan yang sering menjadi kendala bagi pemerintah daerah untuk melakukan tindakan yang efektif. Menyadari bahwa pemerintah daerah sering kurang pengalaman dalam menggalang partisipasi masyarakat di bidang perencanaan dan pemantauan, bagian ini menyajikan panduan langkah demi langkah tentang cara bertindak.

Metode yang diuraikan dalam buku ini telah diuji dan disempurnakan secara bersama-sama dengan masyarakat hutan di Bolivia dan Indonesia. Contoh-contoh dari pengalaman masyarakat tersebut memperjelas teks ini, sekaligus memberi inspirasi bagi pihakpihak yang ingin mengikuti jejak langkah mereka. Buku panduan ini dapat menjadi acuan berharga bagi setiap pihak yang berniat untuk bermitra dengan masyarakat hutan dalam menanggulangi kemiskinan dan meningkatkan kesejahteraan.

Frances Seymour

Director General, CIFOR

Juni 2007 
Belatiku tergelincir, menancap dalam di kakiku. Kugunakan bajuku untuk membebatnya dan aku berjalan tiga jam menyusuri jalan-jalan setapak hutan untuk sampai ke rumah. Tetanggaku menjahit luka itu, tapi luka itu terinfeksi dan aku tidak dapat bekerja selama sebulan. Sawahku gagal panen-panenanku hanya cukup untuk benih musim depan. Anakku ingin masuk SMP, tapi aku tidak punya uang. Kami tidak lagi memperoleh pemasukan dari kayu hutan. Nama kami dipakai, tapi kami tidak pernah mendapatkan manfaat apa pun. Istriku berjuang untuk melahirkan selama tiga hari. Dia akan melahirkan anak pertama kami. Pada hari kelima sebuah pesawat misionaris menerbangkan kami ke rumah sakit yang berjarak 120 km. Istri dan anakku meninggal sebelum kami sampai tujuan.

Panen kacang Brasil berlangsung sangat sebentar dan kadang-kadang produksi turun secara drastis, yang membuat kami sulit untuk hidup dari satu produk saja. Kami memiliki hutan yang kaya tapi pasar sangat jauh; apa yang bisa kami lakukan? Sebelumnya, dengan adanya investor, kami miskin, tetapi dia selalu ada bila kami membutuhkan sesuatu secara mendadak. Sekarang, jika seseorang jatuh sakit, kami hanya sendirian. patron Tidak ada seorang pun yang memedulikan kami. Kami terlampau miskin.

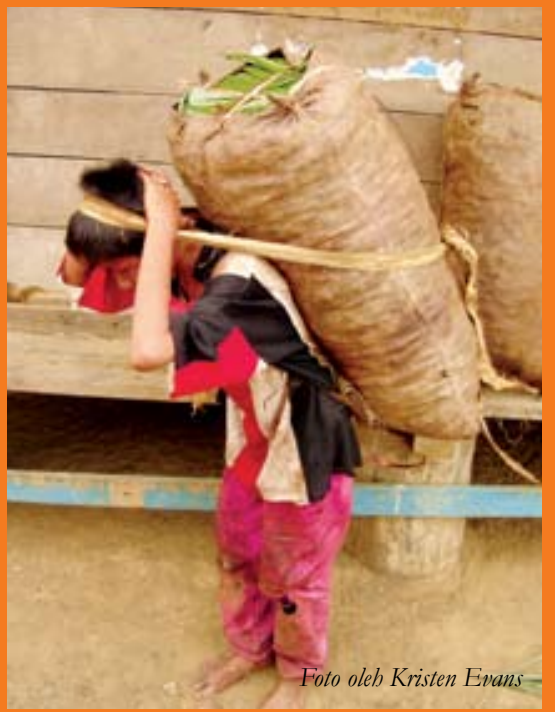




\section{Pengantar}

Kerasnya kemiskinan dirasakan betul oleh masyarakat yang tinggal di kawasan hutan alam di negara-negara berkembang. Kebanyakan mereka terbiasa dengan sulitnya hidup di tempat terpencil, jauh dari layanan kesehatan dan pendidikan yang memadai atau kesempatan untuk mendapatkan uang tunai. Di masa lalu, upaya pembangunan kesulitan untuk menjangkau masyarakat yang tinggal di kawasan berhutan, dan akibatnya mereka yang tinggal di sana dianggap terlalu marjinal untuk dilayani.

Keadaan mulai berubah. Banyak negara mulai mengalihkan anggaran dan tanggung jawab pengambilan keputusannya kepada pemerintah di tingkat daerah, seperti kabupaten, kotamadya atau panchayat (dewan desa), yang secara fisik lebih dekat dengan masyarakat dan hutan. Di negara-negara yang sangat desentralistis, pemerintah daerah sekarang memegang mandat untuk mengurangi kemiskinan.

Pemerintah daerah berada pada posisi yang baik untuk mengurangi kemiskinan masyarakat hutan. Pemerintah daerah dapat lebih memahami karakteristik kemiskinan yang khas di kawasannya dan kemungkinan yang relevan untuk menguranginya. Mereka memiliki kesempatan yang lebih baik untuk secara langsung mendengar dan bekerja dengan masyarakat miskin. Pemerintah daerah seringkali menjadi otoritas lokal yang bertanggung jawab mengkoordinasikan aktivitas pembangunan lain di daerahnya.

Tetapi pemerintah daerah di kawasan hutan mengalami tantangan besar dalam upaya mengurangi kemiskinan ini. Pertama, mereka harus mengatasi kesulitan yang terkait dengan hunian warga yang berpencar jauh dan infrastruktur yang buruk. Kedua, mereka harus secara cermat mengelola hubungan dan menyeimbangkan pembangunan ekonomi, pengurangan kemiskinan dan pengelolaan sumber daya alam. Ketiga, banyak pemerintah daerah yang merupakan bentukan baru, dan karenanya mereka kekurangan kemampuan, kekuasaan atau sarana untuk mengurangi kemiskinan secara efektif. Keempat, banyak pemerintah daerah kekurangan saluran komunikasi yang memadai yang dapat membantu mereka lebih memahami masalah dan prioritas yang dihadapi oleh beragam kelompok masyarakat miskin. Selain itu, pemerintah daerah harus mengatasi korupsi dan jeratan kalangan elit, yang sering timbul dengan mengorbankan kepentingan masyarakat miskin.

Pemerintah daerah akan dapat lebih meningkatkan kesejahteraan jika mereka memiliki alat dan strategi yang andal untuk:

- Mengidentifikasi karakteristik kemiskinan di daerahnya

- Merencanakan intervensi pembangunan yang relevan untuk daerahnya

- Memantau dampak dari intervensi tersebut

Buku panduan ini memberikan empat alat yang dapat digunakan pemerintah daerah untuk lebih memahami kondisi kemiskinan di daerahnya dan merencanakan serta memantau tindakan untuk mengurangi kemiskinan.

Meskipun terdapat banyak alat di tingkat nasional dan internasional, pemerintah daerah memerlukan pendekatan yang dapat mereka sesuaikan dengan lingkungannya sendiri. Alat-alat yang diuraikan dalam buku panduan ini dilandaskan pada pengalaman yang luas dalam perencanaan masyarakat dan pemantauan kemiskinan di kawasan pedesaan. Alat-alat tersebut telah disesuaikan dengan konteks hutan di lokasi kita dan mestinya dapat membantu memperbaiki komunikasi antara masyarakat setempat dan pemerintah daerah sehingga para pengambil keputusan dapat menyesuaikan intervensinya dengan kebutuhan, preferensi dan kondisi lokal. Alat-alat tersebut adalah: 
- Memantau kemiskinan lokal melalui pemetaan interaktif

- Memantau kesejahteraan rumah tangga melalui survei berdasarkan indikator lokal

- Mengevaluasi program pemerintah daerah melalui kelompok fokus masyarakat

- Mengkomunikasikan kebutuhan masyarakat melalui perencanaan berbasis skenario.

Alat-alat ini dirancang untuk digunakan oleh pemerintah daerah, tetapi masyarakat setempat, LSM atau kelompok pengguna lain mungkin dapat juga memanfaatkannya. Sebagian alat mungkin lebih cocok daripada alat yang lain di tempat tertentu. Oleh karena itu, pengguna perlu menyesuaikan alatalat ini dengan konteks mereka sendiri.

Buku Panduan ini terdiri dari dua bagian. Bagian 1 menyajikan informasi latar belakang tentang lokasi tempat kami melakukan penelitian yang kemudian menghasilkan buku ini, dan tentang metodologi yang digunakan. Bagian ini juga memperkenalkan beberapa konsep yang terkait dengan kemiskinan dan kesejahteraan, dan secara ringkas membahas peran pemerintah daerah dan hutan dalam kesejahteraan masyarakat setempat. Bagian 2 mengurai keempat alat dan cara menggunakannya.

Buku panduan ini menggunakan contoh-contoh dari lokasi di Indonesia dan Bolivia, dimana alat-alat tersebut dikembangkan dan diuji. Indonesia dan Bolivia dipilih untuk mewakili dua jenis pemerintahan daerah yang sangat berbeda di kawasan hutan yang menerima tekanan pembangunan yang beragam.

Kami berharap pemerintah daerah, praktisi pembangunan dan lembaga masyarakat sipil dapat menggunakan alat-alat ini dalam pekerjaan mereka.

\section{Metode}

Buku panduan dan alat ini dikembangkan melalui uji lapangan berulang-ulang yang dilakukan bekerja sama dengan pemerintah daerah dan masyarakat di Kalimantan Timur, Indonesia dan Pando, Bolivia, dalam kurun 4 tahun. Di Kalimantan Timur, kami bekerja sama dengan pemerintah kabupaten Malinau dan Kutai Barat, sementara di Pando kami bekerja sama dengan pemerintah kota El Sena, Bolpebra dan Santa Rosa.

Upaya kami ini merupakan bagian dari proyek yang lebih besar yang bertema 'Making local government more responsive to the poor: Developing indicators and tools to support sustainable livelihood development under decentralisation' (Menjadikan pemerintah daerah lebih tanggap terhadap warga miskin: Mengembangkan indikator dan alat untuk mendukung pembangunan perikehidupan yang berkelanjutan dalam desentralisasi). Proyek ini dijalankan bersama oleh Center for International Forestry Research (CIFOR), University of Freiburg dan mitra lokal di Indonesia dan Bolivia untuk meningkatkan upaya pemerintah daerah dalam mengurangi kemiskinan pada masyarakat yang menggantungkan hidupnya pada hutan. Dana proyek ini disediakan oleh Bundesministerium für Wirtschaftliche Zusammenarbeit und Entwicklung (BMZ). Pekerjaan yang terkait dengan alat keempat, 'Mengkomunikasikan kebutuhan masyarakat melalui perencanaan berbasis skenario', dilaksanakan bersama-sama dengan proyek 'Stakeholders and biodiversity in the forest at the local level' [Pemangku kepentingan dan keanekaragaman hayati di hutan pada tingkat lokal], yang didanai oleh Swiss Agency for Development and Cooperation.

Banyak gagasan dan pengamatan dalam buku panduan ini merupakan hasil aktivitas yang dilakukan selama berlangsungnya proyek. Aktivitas tersebut antara lain kajian literatur, survei 
rumah tangga dan diskusi kelompok fokus masyarakat di Pando dan Kalimantan Timur, lokakarya dengan pemerintah daerah, analisis kebijakan dan tindakan pemerintah daerah, dan lokakarya internasional tentang kemiskinan dan desentralisasi (Mei 2006, Lake Constance, Jerman), serta riset tesis/disertasi sejumlah mahasiswa MSc dan PhD.

Alat-alat yang dipaparkan pada Bagian 2 telah berhasil diuji dan disempurnakan selama beberapa putaran penelitian tindakan di kedua lokasi.

\section{Lokasi}

\section{Mengapa Pando dan Kalimantan Timur?}

Pando dan Kalimantan Timur mewakili kawasan dengan sumber daya hutan yang luas dimana pemerintah daerahnya sedang berupaya untuk mengatasi kemiskinan:

- Kedua kawasan tergolong miskin, meskipun data kemiskinan resmi tidak dapat diandalkan;

- Kedua kawasan sebagian besar masih tertutup hutan dan secara ekonomi bergantung pada sumber daya hutan;

- Desentralisasi masih relatif baru di kedua negara, meskipun Bolivia telah memulai proses ini hampir satu dekade lebih awal dibandingkan Indonesia;

- Di kedua negara, desentralisasi ditujukan untuk meningkatkan partisipasi publik, meskipun hasilnya cukup bervariasi di kedua lokasi ini;
- Kedua kawasan jauh dari ibu kota negara, dan karenanya menghadapi masalah yang khas dialami area pedesaan terpencil;

- Di kedua area, CIFOR memiliki riwayat penelitian yang panjang sehingga pemahamannya tentang konteks lokal lebih dalam.

Pada saat bersamaan, Pando dan Kalimantan Timur menunjukkan perbedaan kemampuan administratif dan sumber daya yang penting. Ukuran, kapasitas dan pengaruh keduanya sangat kontras: kotamadya kecil dengan infrastruktur yang buruk di Bolivia dibandingkan dengan kabupaten yang luas dan relatif terdanai di Indonesia. Misalnya, kabupaten-kabupaten di Kalimantan Timur memiliki anggaran tahunan (2003) sekitar US\$ 58 juta (Malinau) sampai US\$ 74 juta (Kutai Barat) dan produk domestik bruto (PDB) antara US\$ 56 juta (Malinau) dan US\$ 278 juta (Kutai Barat) yang sebagian besar diperoleh dari sektor pertambangan dan kehutanan. Kabupaten-kabupaten di Indonesia memiliki unit administratif dan teknis yang luas. Sebaliknya, kotamadya-kotamadya di Pando memiliki sumber daya yang lebih sedikit dari sisi anggaran dan staf. Anggaran tahunan El Sena untuk 2003 adalah sekitar US\$350.000, meskipun perubahan distribusi pajak langsung hidrokarbon meningkatkan anggaran tahunan (2005) hingga sekitar US\$ 1.125 .000 .

Kalimantan Timur dan Pando juga menghadapi tantangan administratif yang berbeda. Masyarakat Kalimantan Timur umumnya tinggal di pemukiman inti, sedangkan masyarakat Bolivia lebih memencar. Rata-rata jumlah penduduk di suatu komunitas juga jauh lebih banyak di Kalimantan (30-1000 orang per komunitas di Malinau). Komunitas di Pando memiliki kawasan yang lebih luas dan populasinya cenderung lebih kecil (30-200 orang per komunitas di El Sena).

Analisis rinci tentang desentralisasi dan kemiskinan di Pando dan Kalimantan Timur dapat dilihat dalam laporan lokasi yang lain (lihat Fuentes dkk. 2005). 


\section{Pemerintah kota dan desentralisasi di Bolivia}

Bolivia merupakan salah satu negara pertama yang mereaksi dampak negatif dari transisi ekonomi berorientasi pasar neo-liberal dengan mengadopsi kebijakan yang mendorong inklusi sosial. Pada tahun 1990-an, negara ini memulai proses desentralisasi yang secara mendasar mengubah peran pemerintah daerah melalui serangkaian perubahan kebijakan yang meliputi Municipalities Law, ${ }^{1}$ Popular Participation Law ${ }^{2}$ dan Administrative Decentralisation Law. ${ }^{3}$ Perubahan meluas hingga menjangkau Poverty Reduction Strategy ${ }^{4}$ negara yang menetapkan peran penting pemerintah kotamadya dalam penanggulangan kemiskinan. Selain itu, dua undang-undang sektoral, Forestry Law ${ }^{5}$ dan Agrarian Reform Law ${ }^{6}$ yang baru, meski tidak memberi banyak wewenang terhadap pemerintah daerah, mulai mengatur hak milik dan akses terhadap hutan bagi penduduk pedesaan, sehingga memperkuat posisi politik

1 UU No. 696/1985, direvisi menjadi UU No. 2028/1999.

2 UU No. 1551/1994.

3 UU No. 1654/1995.

4 Poverty Reduction Strategy Papers (PRSP) dibuat oleh pemerintah di negara-negara berpendapatan rendah melalui proses partisipatif yang melibatkan para pemangku kepentingan domestik dan mitra pembangunan eksternal, seperti IMF dan Bank Dunia. PRSP menjabarkan kebijakan makro-ekonomi, struktur dan program yang akan dilaksanakan oleh suatu negara dalam jangka beberapa tahun untuk menciptakan pertumbuhan dengan basis yang luas dan mengurangi kemiskinan, serta kebutuhan pendanaan eksternal dan sumber daya keuangan yang terkait.

5 UU No. $1700 / 1996$.

6 UU No. $1715 / 1996$ dan ekonomi mereka dalam kawasan kotamadya. Dilihat bersama-sama, perubahan-perubahan tersebut menjadi dasar hubungan baru antara pemerintah dan konstituen-konstituennya di negara ini.

Sistem desentralisasi Bolivia mensyaratkan konsultasi langsung antara pemerintah kotamadya dengan organisasiorganisasi masyarakat yang representatif. Susunan administratif pokok kotamadya di Bolivia dapat dilihat pada Gambar 1.

Bila Municipalities Law, yang disahkan tahun 1986, menjadi langkah pertama dalam menentukan pemerintahan kotamadya, Popular Participation Law 1994 menciptakan mekanisme pendanaan pemerintah kotamadya dan partisipasi masyarakat dalam pengambilan keputusan pemerintah kotamadya. Undangundang ini mendistribusikan ulang anggaran nasional melalui 'ko-partisipasi' dan menetapkan 20\% pendapatan negara untuk semua kotamadya di Bolivia. Hal ini dimaksudkan untuk

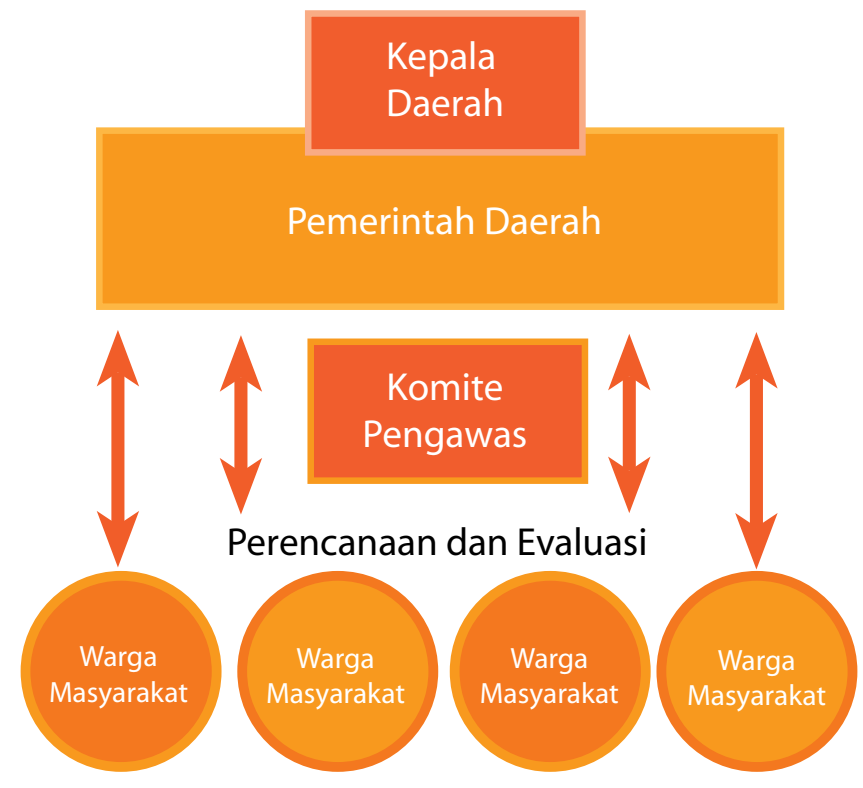

Gambar 1. Susunan administratif kotamadya-kotamadya di Bolivia (disederhanakan). 
memberi penduduk kotamadya hak suara dalam alokasi dana dan pengawasan penggunaannya.

Akan tetapi otonomi pemerintah kotamadya menjadi sangat dibatasi oleh Administrative Decentralisation Law 1995, yang memberikan wewenang fungsi-fungsi pemerintahan penting (termasuk pendidikan dan layanan kesehatan) kepada pemerintah provinsi (prefecture) dan badan-badannya. Aktivitas pembangunan penting yang diarahkan untuk penanggulangan kemiskinan sekarang dikendalikan oleh kantor-kantor Provinsi (Prefecture), yang berarti mengurangi pengaruh pemerintah kotamadya.

Pada tahun 1996, Forestry Law yang baru memberi masyarakat pedesaan dan komunitas pribumi akses ke hutan dan kesempatan untuk memperoleh manfaat dari hutan. Undang-undang ini juga menetapkan sumber pendapatan baru bagi pemerintah kotamadya yang berasal dari pajak dan bea hutan. Agrarian Reform Law 1996 berusaha menciptakan keteraturan dalam hak milik tanah yang kacau dan tumpangtindih di Bolivia. Melalui undang-undang ini dan keputusan presiden (DS25848) yang disiapkan khusus untuk komunitas hutan tropis, desa-desa di Pando mendapatkan hak atas kawasan komunal, yang ukurannya setara dengan 500 hektar per keluarga. Langkah ini mengubah keseimbangan kekuasaan di kawasan pedesaan dengan lebih memprioritaskan hak-hak masyarakat dibandingkan klaim kalangan elit regional, yang sebelumnya mengendalikan kawasan hutan yang sangat luas itu.

\section{Pemerintah kabupaten dan desentralisasi di Indonesia}

Reformasi yang menyertai krisis ekonomi 1998 secara drastis mengubah lanskap administratif dan politik di Indonesia. Otonomi daerah telah memberi pemerintah daerah wewenang dan hak untuk membuat kebijakan secara lebih otonom ${ }^{7}$ dan untuk menata anggarannya secara mandiri. ${ }^{8}$ Sekarang, kabupaten memiliki otonomi penuh untuk mengambil keputusan sesuai dengan kebutuhan dan kondisi khas daerahnya, sehingga tercipta keberagaman daerah. Pemerintah daerah menerima anggaran yang jauh lebih besar dibandingkan sebelumnya, meskipun sebagian wewenangnya akhirnya dikurangi berdasarkan undang-undang yang disahkan belakangan. ${ }^{9}$

Dengan reformasi ini, muncul pengharapan dan asa yang tinggi bahwa Indonesia, khususnya warga miskin di negara ini, akan memiliki masa depan yang lebih cerah. Tetapi, harga makanan dan kebutuhan pokok tetap tinggi, sementara langkah-langkah keras yang diberlakukan lembaga donor semakin mempersulit kehidupan warga miskin. Penurunan angka kemiskinan yang telah dicapai selama dua dasawarsa dirusak oleh krisis keuangan 1998 yang memicu peningkatan kemiskinan secara dramatis. Angka resmi kemiskinan tetap tinggi sejak 2001, dengan hanya sedikit penurunan dalam beberapa tahun terakhir.

Bagi kabupaten terpencil, berhutan dan dahulunya terisolir seperti Malinau dan Kutai Barat, potensi perolehan dari otonomi daerah sangatlah signifikan. Belakangan ini, konsesi kayu hutan sering menjadi sumber utama bantuan pembangunan pemerintah. Akan tetapi jumlah layanan yang menjangkau masyarakat masih sangat sedikit dan secara politik penduduk kabupaten ini masih terpinggirkan. Desentralisasi sekarang menuntut pemerintahan memperbaiki akuntabilitas dan perhatiannya terhadap kebutuhan masyarakat setempat. Pemerintah juga bertanggung jawab memberikan layanan publik, mengelola sumber daya alam daerah dan menciptakan pendapatan lokal.

\footnotetext{
7 UU No. 22/1999.

8 UU No. 25/1999.

9 UU No. 32/2004 dan No. 33/2004.
}

a




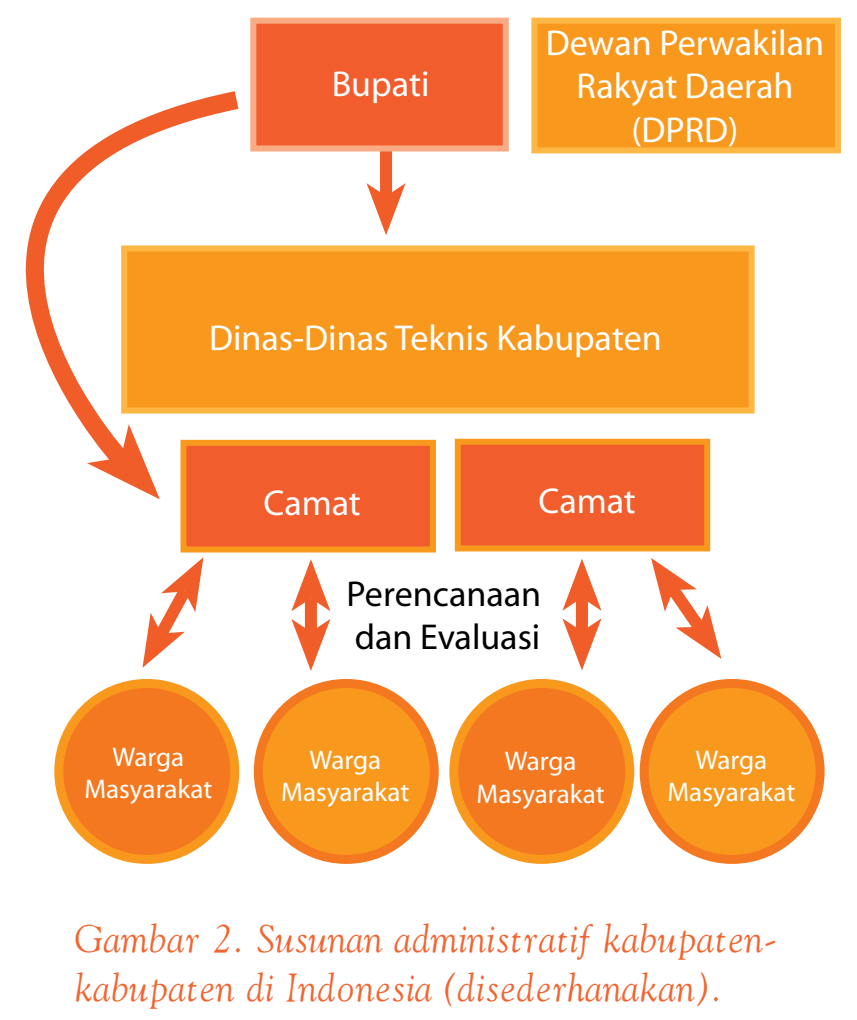

Struktur administratif pokok di kabupaten-kabupaten Indonesia dapat dilihat pada Gambar 2. Tidak seperti contoh dari Pando, terdapat satu lapisan administratif lagi antara masyarakat dan kabupaten-yakni kecamatan-yang memainkan peran penting dalam menyalurkan atau menghambat proposal pembangunan masyarakat ke tingkat pemerintahan yang lebih tinggi.

Serangkaian kebijakan telah diterbitkan selama reformasi desentralisasi yang membentuk minat kabupaten saat ini terhadap kemiskinan. Kebijakan tersebut meliputi tiga hal: (1) gerakan nasional untuk mengembangkan dan menerapkan Strategi Pengurangan Kemiskinan, (2) program bantuan nasional untuk meningkatkan keamanan pangan dan mengurangi kerentanan ekonomi, dan (3) kepentingan masing-masing kabupaten untuk menciptakan masyarakat yang swasembada dan makmur guna mempertahankan keberlangsungan finansial kabupaten tersebut.

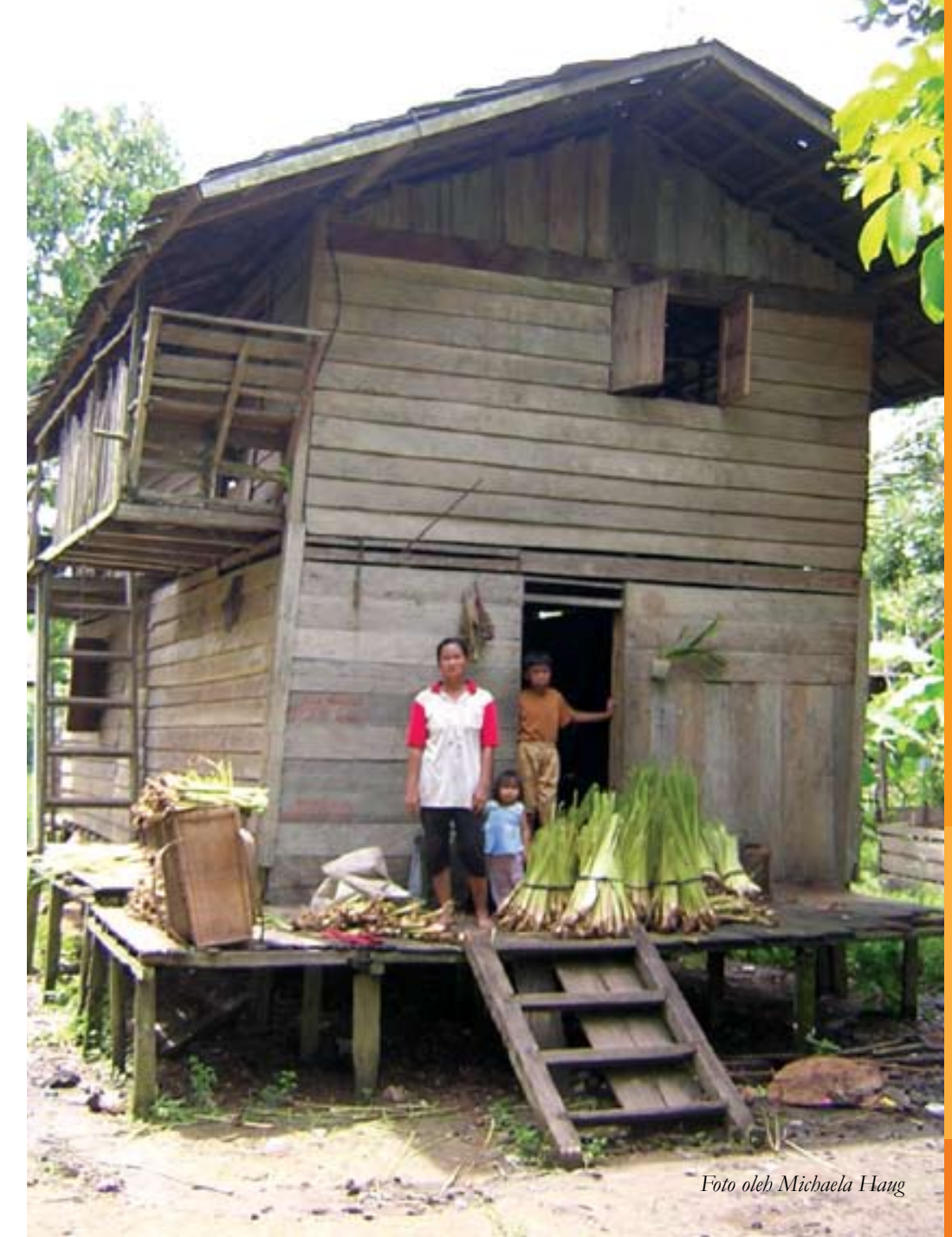


Bagian I.

Konsep

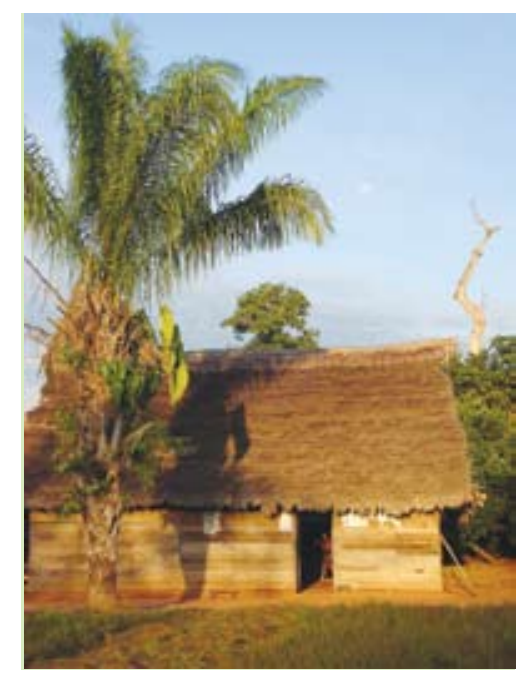




\section{Konsep kesejahteraan dan kemiskinan}

\section{Kemiskinan adalah kurangnya kesejahteraan}

Memahami kesejahteraan dan kemiskinan merupakan langkah pertama untuk mengurangi kemiskinan. Definisi yang bermakna diperlukan untuk mengidentifikasi penyebab kemiskinan, tujuan pengurangan kemiskinan, dan cakupan dari apa yang harus dilakukan.

Pemerintah daerah harus memiliki konsep kesejahteraan dan kemiskinan yang relevan dengan daerahnya yang akan membantu mereka membuat keputusan yang tepat. Konsep yang disajikan di sini dapat dipakai sebagai titik awal pembahasan dalam pemerintah dan masyarakat tentang kemiskinan, kesejahteraan dan hubungan antara keduanya.

Menurunnya kemiskinan berarti naiknya kesejahteraan. Kedua istilah ini saling terkait dan memandang masalah yang sama dari dua sisi yang berbeda. Definisi umum kemiskinan adalah 'kurangnya kesejahteraan' dan kedua istilah tersebut digunakan saling tukar di dalam buku panduan ini. Misalnya, jika seseorang benar-benar kekurangan kesejahteraan, maka dia dalam kemiskinan. Di sisi lain, jika dia berada dalam kondisi yang sangat sejahtera, maka hidupnya ditandai dengan kemakmuran, kebahagiaan dan kepuasan.

Definisi yang tidak konvensional ini berguna untuk mengakomodasi berbagai konsep nasional dan membantu dalam menilai dan menganalisa berbagai dimensi kemiskinan. Lebih dari itu, 'kemiskinan' sering berkonotasi negatif dengan sikap pasif, ketidakmampuan atau keterbelakangan. Penggunaan istilah semacam ini dapat melukai perasaan atau menghina. Istilah 'kesejahteraan' membuat pembahasan tentang kemiskinan dapat dilakukan dari sisi yang lebih positif. Oleh karena itu, 'kemiskinan' sebaiknya dimaknai sebagai 'kurangnya kesejahteraan' dan 'kesejahteraan' sebagai 'berkurangnya kemiskinan'.

\section{Kemiskinan lebih dari sekedar rendahnya pendapatan}

Selama bertahun-tahun, 'miskin' didefinisikan sebagai tidak memiliki cukup uang. Banyak negara terus mengukur kemiskinan hanya dari sisi pendapatan, konsumsi atau akses terhadap layanan. Bahkan hingga sekarang, salah satu definisi kemiskinan yang paling umum adalah garis kemiskinan dengan pendapatan minimum US\$1 per hari. Bank Dunia masih menggunakan standar ini untuk membandingkan kemiskinan secara global.

Memang, uang penting. Dengan uang, orang dapat membeli makanan, obat-obatan dan pendidikan. Tetapi uang saja tidak cukup. Banyak keluarga yang memiliki cukup pendapatan, tetapi kekurangan akses terhadap layanan kesehatan, air minum bersih atau pendidikan formal. Di kasus lain, sebuah keluarga mungkin memiliki pendapatan tunai yang kecil, tetapi dapat memenuhi semua kebutuhan pokoknya. Apakah ini sertamerta berarti bahwa keluarga tersebut miskin?

Sejak pertengahan 1980-an, konsep kemiskinan telah berubah dari pertimbangan pendapatan atau konsumsi yang sederhana menjadi definisi yang mencakup multidimensi kekurangan dan kesejahteraan. Saat ini, organisasi-organisasi 
pembangunan terkemuka seperti Bank Dunia dan UNDP menerapkan definisi kemiskinan yang mencakup aspek-aspek seperti kebutuhan dasar, gaya hidup yang ditentukan sendiri, pilihan, aset, kapabilitas, inklusi sosial, ketidaksetaraan, hak asasi manusia, pemukiman, kerentanan, pemberdayaan dan kesejahteraan subjektif. ${ }^{10}$

\section{Kemiskinan dan kesejahteraan memiliki banyak dimensi}

Kemiskinan adalah kurangnya banyak hal. Kemiskinan berarti kurangnya pendapatan yang memadai untuk memenuhi kebutuhan rumah tangga atau kekurangan kekayaan untuk memberi stabilitas atau menghadapi perubahan seperti kehilangan pekerjaan, sakit atau krisis lainnya. Dapat juga itu berarti bahwa kebutuhan dasar yang lain, seperti kesehatan, pendidikan atau perumahan, tidak memadai. Tetapi kemiskinan juga subjektif, dan dapat disebabkan oleh perasaan, seperti kehilangan, kerentanan, keterkucilan, malu atau sakit. Seseorang dapat merasa miskin jika kesejahteraannya turun, atau jika dia membandingkan dirinya dengan orang lain yang keadaannya lebih baik.

Kemiskinan yang paling parah adalah jika seseorang tidak hanya merasa miskin, tetapi juga kekurangan sarana untuk keluar dari kemiskinan. Kemiskinan tidak hanya 'tidak mempunyai ikan', tetapi juga 'tidak tahu cara menangkap ikan', 'tidak tahu tempat menangkap ikan', 'tidak memiliki jaring' atau 'tidak memiliki hak untuk menangkap ikan'. Selain itu, sering kali memang ikannya tidak ada, karena kolamnya telah

10 Pendekatan kapabilitas dikembangkan oleh pemenang Hadiah Nobel Amartya Sen (misal, Sen 1993, 1997, 1999).
Kotak 1. Secara resmi, siapakah warga miskin itu?

Ada beberapa pendekatan untuk secara resmi menentukan kemiskinan dalam suatu populasi dan menetapkan siapa yang miskin. Salah satunya adalah dengan menarik garis kemiskinan. Garis kemiskinan menandai level konsumsi minimum yang diperlukan untuk memenuhi kebutuhan fisik dasar. Individu yang berada di bawah garis ini dianggap miskin. Kebanyakan negara memiliki definisi sendiri mengenai garis kemiskinan tersebut dan, oleh karena itu, kemiskinan sangat berlainan dari satu negara ke negara lain. Agar bisa melakukan pembandingan lintas negara, PBB dan Bank Dunia menggunakan sejumlah indeks global:

- Bank Dunia dan PBB menyebutnya kemiskinan ekstrem jika masyarakat memiliki pendapatan kurang dari US\$ 1 per hari dalam paritas daya beli.

- Human Development Index (HDI - Indeks Pembangunan Manusia) UNDP mengukur tiga bidang: usia panjang, pengetahuan dan standar kehidupan yang layak. Usia panjang diukur menggunakan persentase orang yang meninggal sebelum usia 40 tahun; pengetahuan diukur dengan tingkat kemampuan baca-tulis penduduk dewasa digabungkan dengan rasio pendaftaran kotor ke pendidikan dasar, menengah dan tinggi; sementara standar kehidupan diukur dengan menggunakan PDB per kapita riil.

- Human Poverty Index UNDP juga menggunakan bidang yang sama, tetapi untuk standar kehidupan HPI menggunakan ukuran akses ke air bersih dan layanan kesehatan, dan persentase anak yang kekurangan berat badan pada usia kurang dari 5 tahun. 
kering atau tercemar. Bagi banyak warga miskin, kemampuan, peluang atau kebebasan untuk melepaskan diri dari kemiskinan tidak ada: mereka terjerat dalam kemiskinan.

Untuk menangkap semua sisi kemiskinan dan kesejahteraan ini, diperlukan konsep multidimensi. Salah satu pendekatannya adalah model Nested Spheres of Poverty (NESP) (Gönner dkk. 2007). Pada model NESP, kemiskinan dan kesejahteraan tersusun atas berbagai lingkungan, atau aspek kehidupan sehari-hari yang berbedabeda. Lingkungan tengah dalam model ini adalah kesejahteraan subjektif. Lingkungan inti yang mempengaruhi kesejahteraan subjektif adalah kesehatan, kekayaanmateridanpengetahuan. Ketiga hal ini-dan secara tidak langsung, kesejahteraan subjektif-dipengaruhi oleh lingkungan konteks. Yang dimaksud lingkungan konteks di sini adalah aspek alam, ekonomi, sosial dan politik kehidupan yang langsung atau tidak langsung mempengaruhi lingkungan inti. Berikutnya, lingkungan konteks dipengaruhi oleh prasarana dan layanan.

Secara grafis, gagasan NESP di atas dapat diwakili dengan serangkaian lingkaran konsentris (lihat Gambar 3). Bagian tengahnya terbentuk dari kesejahteraan subjektif (SJS), dan dikelilingi oleh aspek inti kemiskinan, termasuk kebutuhan dasar, dan konteks yang memungkinkan warga miskin untuk keluar dari kemiskinannya.

Kesejahteraan subjektif bersifat sangat individu dan emosional. Kesejahteraan ini tidak memiliki nilai konstan, tetapi berubah-ubah sesuai dengan suasana hati dan lingkungan. Orang membandingkan standar kehidupan mereka dengan standar kehidupan orang lain atau dengan kesejahteraan mereka sebelumnya. Perasaan pribadi seperti kebahagiaan, keamanan, keterlibatan dan kepuasan, ikut menyumbang kesejahteraan subjektif secara keseluruhan. Bentuk-bentuk kesejahteraan lain juga tercakup, seperti kesejahteraan jasmani, kesejahteraan sosial, kepemilikan martabat diri atau perasaan aman dan terjamin.

Inti pada model ini mencakup 'kebutuhan dasar' seperti makanan, kesehatan, perumahan dan pendidikan. Yang juga tercakup adalah kapabilitas individu secara umum (yakni, kecakapan dan kondisi fisik) untuk keluar dari kemiskinan. Pada model NESP, kebutuhan dasar dan kapabilitas individu digabung menjadi tiga kategori: kesehatan, kekayaan materi dan pengetahuan (formal, informal atau tradisional). Bagi kebanyakan masyarakat lokal Indonesia, inti ini juga disebut sebagai aspek pokok kemiskinan. Bersama-sama dengan kesejahteraan subjektif, inti ini merupakan ukuran kemiskinan atau kesejahteraan yang baik pada suatu rumah tangga.

Dari kelima lingkungan konteks, lingkungan alam mencerminkan ketersediaan dan mutu sumber daya alam. Lingkungan ekonomi mencakup kesempatan ekonomi dan jaring pengaman. Aspek-aspek seperti kapital dan kekompakan 
sosial, rasa saling percaya dan konflik, membangun lingkungan sosial. Lingkungan politik terdiri dari hak dan partisipasi atau representasi dalam pengambilan keputusan, pemberdayaan dan kebebasan. Lapisan luar model NESP adalah lingkungan konteks kelima, yang mempengaruhi keempat lingkungan konteks yang lain: prasarana dan layanan. Keduanya sebagian besar disediakan oleh badan-badan pemerintah, LSM, proyek pembangunan dan sektor swasta. Konteks ini adalah lingkungan pendukung yang menyokong usaha-usaha inisiatif sendiri untuk keluar dari kemiskinan, mengurangi kerentanan terperosok ke dalam kemiskinan atau terjebak di dalam kemiskinan secara kronis.

Dinamika dan kausalitas kemiskinan tercermin dalam lapisanlapisan yang berlainan pada model NESP ini. Kesejahteraan subjektif bersifat sangat sementara. la sering berubah-ubah karena banyak pengaruh. Tetapi kesejahteraan subjektif juga terkait dengan kombinasi aspek-aspek inti. Karenanya, peningkatan kesejahteraan inti umumnya juga meningkatkan kesejahteraan subjektif. Dengan bahasa yang sama, penurunan kesejahteraan inti biasanya juga berarti turunnya kesejahteraan subjektif.

Pada skala waktu yang lebih panjang, baik kesejahteraan inti maupun kesejahteraan subjektif dipengaruhi oleh konteks. Misalnya, pengetahuan meningkat sebagai akibat dari membaiknya pendidikan, kondisi kesehatan menurun karena polusi lingkungan, kesejahteraan subjektif turun karena adanya konflik sosial. Oleh karena itu, terdapat jalinan sebab akibat yang kuat antara bagian yang ada di tengah dan luar inti lingkaran.

Kategori-kategori yang disajikan dalam model NESP ini bersifat komprehensif. Mereka mencakup kebutuhan dasar dan kondisi lingkungan pendukung. Untuk suatu latar tertentu, pemerintah daerah dapat menentukan lingkungan dan indikatornya sesuai dengan prioritasnya sendiri. Alat kedua yang disajikan dalam buku panduan ini adalah aplikasi praktis model NESP. Di situ ditunjukkan cara mengembangkan indikator lokal yang relevan dan cara memvisualisasikan kondisi setiap lingkungan kesejahteraan dengan menggunakan kode warna sederhana. Juga memungkinkan seseorang untuk menilai 'imbangan' antara menaikkan satu lingkungan (misal, lingkungan ekonomi) dan dampaknya pada lingkungan yang lain (misal, lingkungan alam).
Referensi dan bacaan lebih lanjut

Angelsen, A. and Wunder, S. 2003 Exploring the forestpoverty link: key concepts, issues and research implications. Occasional Paper No. 40. CIFOR, Bogor, Indonesia.

Barrett, C. 2006 Poverty traps and resource dynamics in smallholder agrarian systems. SAGA Working Paper. Cornell University, USA.

Cahyat, A., Gönner, C. and Haug, M. 2007 Poverty monitoring manual. (CIFOR-BMZ Poverty and Decentralization Project.) CIFOR, Bogor, Indonesia.

Carter, M.R. and Barrett, C.B. 2006 The economics of poverty traps and persistent poverty: an assetbased approach. Journal of Development Studies 42(2): 178-199.

Chambers, R. and Conway, G.R. 1991 Sustainable rural livelihoods. Practical concepts for the 21st century. IDS Discussion Paper 296.

Fuentes, D., Haches, R., Maldonado, R., Albornoz, M., Cronkleton, P., de Jong, W., Becker, M. 2005 Pobreza, Descentralización y Bosque en la Amazonia Boliviana. Centro Internacional para la Investigación Forestal. Editorial El País, Santa Cruz, Bolivia.

Gönner, C., Haug, M., Cahyat, A., Wollenberg, L., de Jong, W., Limberg, G., Cronkleton, P., Moeliono, M. and Becker, M. 2007 Capturing nested spheres of poverty: a model for multi-dimensional poverty analysis and monitoring. Occasional Paper No. 46. CIFOR, Bogor, Indonesia.

Kanbur, R. and Squire, L. 1999 The evolution of thinking about poverty: exploring the interactions. Makalah 
Latar Belakang untuk the World Development Report. The World Bank, Washington, DC.

Narayan, D., Patel, R., Schafft, K., Rademacher, A. and Koch-Schulte, S. 2000 Voices of the poor: can anyone hear us? Oxford University Press untuk Bank Dunia, New York.

Narayan, D., Chambers, R., Kaul Shah, M. and Petesch, P. 2000 Voices of the poor: crying out for change.Oxford University Press untuk Bank Dunia, New York.

Narayan, D. and Petesch, P. 2002 Voices of the poor: from many lands. Oxford University Press untuk Bank Dunia, New York.

Ravallion, M. [undated] How not to count the poor? A reply to Reddy and Pogge. (Tersedia di: http://www.columbia.edu/ sr793/wbreply. pdf.)

Reddy, S.G. and Pogge, T. 2005 How not to count the poor. (Tersedia di SSRN: http://ssrn.com/abstract=893159.)

Scoones, I. 1998. Sustainable rural livelihoods: a framework for analysis. Working Paper 72. Institute for Development Studies, Brighton, UK.

Sen, A.K. 1993 Capability and well-being. In: Nussbaum, M.C. and Sen, A.K. (eds.) The quality of life. Clarendon Press, Oxford, UK.

Sen, A.K. 1997 Editorial: Human capital and human capability. In: World Development 25(12): 1959-1961.

Sen, A.K. 1999 Development as freedom. Oxford University Press, Oxford, UK.

Streeten, P.P., Burki, S.J., ul Haq, M., Hicks, N. and Stewart, F. 1981 First things first, meeting basic human needs in developing countries., Oxford University Press, New York.

Sumner, A. 2004 Economic wellbeing and non-economic wellbeing: a review of the meaning and measurement of poverty. WIDER Research Paper No. 2004/30. (Tersedia di: http://www.wider.unu.edu/publications/ rps/rps2004/rp2004-030.pdf.)

UNDP (United Nations Development Programme) 2005 Human development report. Oxford University Press, New York.

World Bank 2000/01 World development report (WDR) 2000/2001: attacking poverty. The World Bank, Washington, DC..

World Bank 2002 A sourcebook for poverty reduction strategies. The World Bank, Washington, DC. 
Bagaimana pemerintah daerah dapat mempengaruhi kemiskinan?

Pemerintah daerah memiliki potensi yang sangat besar untuk mempengaruhi kemiskinan. Tetapi mereka sering kesulitan dalam menentukan prioritas, menetapkan strategi dan mengambil tindakan. Panduan berikut dapat membantu pemerintah mengidentifikasi aspek-aspek kemiskinan yang ingin dipengaruhinya.

\section{Apa yang dapat dilakukan pemerintah daerah?}

Cakupan kemampuan pemerintah daerah untuk menyikapi kemiskinan dipengaruhi oleh kerangka hukum yang disediakan oleh proses desentralisasi, sumber daya yang tersedia dan keputusan yang dibuat untuk menggunakan hak-hak dan sumber daya tersebut (Kotak 2). Di sini perlu dilihat apakah faktor-faktor yang mendorong kemiskinan dapat benar-benar dipengaruhi oleh pemerintah daerah untuk menentukan strategi tindakan-tindakannya.

Kotak 2. Cakupan kemampuan pemerintah daerah untuk mempengaruhi kemiskinan dan kendala tindakan

\begin{tabular}{|c|c|c|}
\hline $\begin{array}{c}\text { Pemerintah daerah memiliki kewenangan, tetapi } \\
\text { tidak menggunakannya }\end{array}$ & $\begin{array}{c}\text { Pemerintah daerah dapat } \\
\text { mempengaruhi kemiskinan tetapi } \\
\text { tidak memiliki mandat berdasarkan } \\
\text { kebijakan yang ada }\end{array}$ & $\begin{array}{l}\text { Di luar kendali } \\
\text { pemerintah }\end{array}$ \\
\hline $\begin{array}{l}\text { - Kurang kemauan untuk menegakkan peraturan } \\
\text { - } \text { Alokasi dana untuk program penanggulangan } \\
\text { - Kemiskinan rendah } \\
\text { - } \text { Institusi atau mekanisme untuk menangani } \\
\text { konflik tidak memadai } \\
\text { - Komunikasi dengan masyarakat lemah dan } \\
\text { informasi tentang kondisi pedesaan kurang. }\end{array}$ & $\begin{array}{l}\text { - Tidak memiliki wewenang atas } \\
\text { sumber daya hutan } \\
\text { - Kerangka koordinasi dengan } \\
\text { badan pemerintah yang lain } \\
\text { kurang } \\
\text { - Tidak ada check and balance } \\
\text { untuk mengurangi korupsi. }\end{array}$ & $\begin{array}{l}\text { - } \text { Bencana alam } \\
\text { - } \text { sulit } \\
\text { - Tanah tidak subur } \\
\text { - Harga yang tidak } \\
\text { bersahabat } \\
\text { di pasar } \\
\text { internasional }\end{array}$ \\
\hline
\end{tabular}


Ada banyak alasan mengapa pemerintah daerah, yang memiliki mandat hukum dan wewenang untuk mempengaruhi kemiskinan, tidak mengambil tindakan yang efektif. Pemerintah mungkin kurang memiliki kemauan politis akibat perang kepentingan, bias atau korupsi dan, sebagai akibatnya, tidak memprioritaskan pengurangan kemiskinan dalam mengambil keputusan. Kemampuan pemerintah untuk bertindak secara efektif berkurang jika ia tidak memiliki sumber daya atau staf yang memadai, atau jika biaya tindakan terlampau tinggi. Seringkali, pemerintah tidak memiliki informasi yang cukup mengenai kemiskinan lokal; misalnya, tidak tahu di mana warga miskin berada atau mengapa mereka menjadi miskin. Bahkan, sekalipun informasi kemiskinan tersedia, pemerintah daerah bisa juga kurang mampu menyintesis informasi itu atau merancang strategi untuk meresponsnya.

Pada situasi lain, pemerintah daerah sebenarnya dapat mempengaruhi kemiskinan secara potensial, tetapi kebijakan desentralisasi atau reformasi terkait tidak memberinya mandat atau kondisi untuk bertindak. Misalnya, pemerintah daerah sebenarnya memiliki hasrat untuk membantu masyarakat menyelesaikan konflik hak harta milik, atau memiliki pengetahuan rinci untuk membantu meningkatkan manajemen hutan, tetapi mereka tidak bertindak karena tidak memiliki yurisdiksi atas sumber daya hutan. Kerangka hukum yang mengatur pendanaan bagi badan-badan pemerintah mungkin mengalirkan dana yang diperoleh dari pajak dan bea pemanfaatan hutan ke jenjang pemerintahan lain, sehingga pemerintah daerah tidak memiliki kepentingan khusus untuk menciptakan manajemen hutan yang berkelanjutan atau distribusi manfaat yang adil.

Meskipun kami merujuk pada kebijakan desentralisasi, kami menyadari bahwa reformasi sering menghasilkan deretan perubahan kebijakan yang lebih besar yang dapat menghadirkan dampak langsung bagi pemerintah daerah. Perubahan rejim nasional dan reformasi partisipasi politik, kebebasan menyampaikan pendapat, pasar, lahan atau kehutanan biasanya menyertai desentralisasi. Rangkaian kebijakan ini perlu dipahami untuk memahami cakupan tindakan lengkap yang mungkin dilakukan pemerintah daerah. Sayangnya, implikasi kebijakan baru sering tidak jelas dan masih diperlukan waktu untuk menentukan bagaimana kebijakan itu berjalan dan dimana kesenjangan tercipta. Dalam hal pemerintah daerah tidak memiliki mandat hukum, mereka perlu bekerja bersama dengan badan-badan lain yang memiliki yurisdiksi, mendukung reformasi kebijakan atau mendukung peran lembaga masyarakat sipil. Pemerintah daerah perlu terus mengikuti kebijakan dan program pembangunan di tingkat nasional dan daerah untuk memastikan bahwa program lokal yang dihasilkan efisien dan mampu bertahan.

Terlepas dari desain sistem desentralisasi, banyak penyebab kemiskinan yang berada di luar kendali pemerintah daerah. Contohnya adalah bencana alam, penyusutan sumber daya atau harga yang ditetapkan oleh pasar internasional. Dalam kasus semacam ini, jika jelas bahwa pemerintah daerah tidak dapat mempengaruhi penyebabnya secara langsung, maka pemerintah daerah harus memfokuskan tindakannya untuk mengurangi dampak negatif yang ditimbulkan. Pemerintah daerah mungkin perlu meminta bantuan kepada lembagalembaga eksternal, mencari strategi ekonomi alternatif atau menuntut kompensasi kerugian.

Jika pemerintah daerah memiliki mandat dan kewenangan, mereka dapat mengambil tindakan segera dan langsung. Jika pemerintah daerah tidak memiliki mandat, tetapi memiliki potensi untuk mempengaruhi kemiskinan, strateginya harus dialihkan ke arah kolaborasi dan advokasi dengan kelompok lain yang memiliki wewenang. Jika pemerintah daerah tidak mungkin dapat mempengaruhi penyebab kemiskinan tertentu, maka langkah yang paling tepat adalah menyiapkan diri untuk, atau mengurangi dampak dari, penyebab tersebut. 


\section{Kotak 3. Apa yang dilakukan pemerintah daerah untuk mengurangi kemiskinan di Pando?}

Pemerintah kotamadya di Pando masih terus mengatur tugas-tugas dan kesempatan baru mereka sejak reformasi desentralisasi dimulai. Tetapi sejumlah keberhasilan telah diraih. Pemerintah kotamadya telah menanggapi permintaan desa-desa untuk membangun sistem pengairan, gedung sekolah dan jalan-jalan, dan menyediakan generator listrik ukuran kecil. Dan, kendati layanan kesehatan dan pendidikan disediakan oleh badan di luar pemerintah kotamadya, dewan kotamadya tetap memainkan peran dengan menunjuk anggota yang mengawasi implementasi layanan ini.

Di bidang politik, pemerintah kotamadya berhasil meningkatkan partisipasi konstituennya dalam pengambilan keputusan secara signifikan. Tetapi proses ini masih jauh dari hasil yang diharapkan.

Karena keterbatasan dana, kemampuan pemerintah kotamadya untuk mempengaruhi kesejahteraan keluarga masih terbatas. Kotamadya menerima dana dari pemerintah pusat berdasarkan jumlah penduduk lokalnya; tetapi mereka seringkali kesulitan untuk mengetahui jumlah penduduk yang sebenarnya. Menentukan jumlah penduduk Pando merupakan pekerjaan berat karena buruknya pemetaan perbatasan dan terjadinya migrasi tenaga kerja musiman selama masa panen kacang Brasil—di beberapa kotamadya jumlah penduduknya bisa membengkak sampai tiga kali lipat jumlah resmi' selama musim kacang Brasil. Meskipun para migran ini bukan merupakan konstituen formal pemerintah kotamadya dan tidak disertakan dalam alokasi anggaran per kapita, tetapi pemerintah daerah sering harus menyediakan layanan bagi mereka. Seperti dikatakan walikota $\mathrm{El}$ Sena, warga migran dapat menjadi kendala signifikan dalam penetapan anggaran lokal, seperti biaya layanan kesehatan selama musim malaria.

Desentralisasi memang memperluas tanggung jawab dan kekuasaan pemerintah kotamadya untuk membantu penduduk lokal. Akan tetapi upaya ini sering diduplikasi atau dikecilkan oleh program-program yang jauh lebih besar yang dijalankan oleh pemerintah provinsi (prefecture). Tanggung jawab provinsi mencakup infrastruktur, pendidikan, layanan kesehatan, manajemen sumber daya alam dan penguatan kotamadya. Sampai belum lama ini, orang-orang yang mengepalai provinsi tersebut adalah hasil penunjukan politis, dan bukan perwakilan yang dipilih langsung oleh warga provinsi. Mereka terkenal tidak tanggap terhadap kebutuhan publik, tidak efektif dan, dalam beberapa hal, korup. Reformasi 2005 yang mensyaratkan pemilihan gubernur secara langsung membawa harapan besar bahwa para pejabat provinsi akan lebih tanggap dan bertanggung jawab terhadap para pemilihnya, meskipun indikasi awal dari hal ini masih samar-samar.

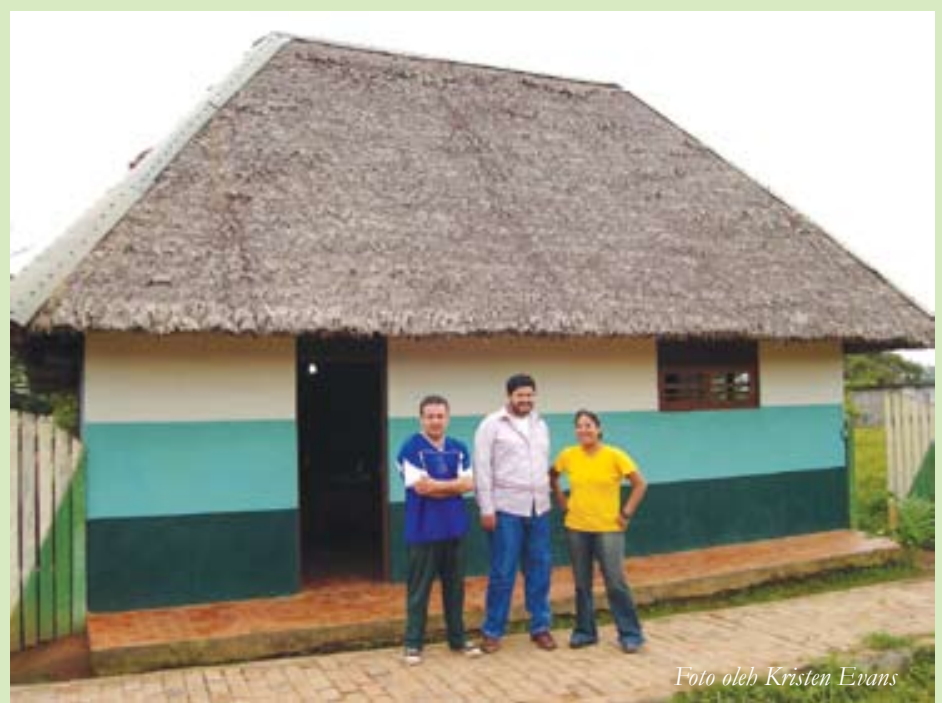




\section{Empat langkah untuk meningkatkan tindakan pemerintah daerah}

Ada empat langkah yang dapat diambil pemerintah daerah untuk meningkatkan rasa tanggap mereka terhadap warga miskin:

1. Memahami kemiskinan/kesejahteraan lokal

2. Berkomunikasi dan berkoordinasi dengan warga miskin

3. Mengambil tindakan yang menguntungkan warga miskin

4. Mendapatkan keseimbangan antara berbagai aspek kesejahteraan.

Keempat langkah ini didasarkan pada pengamatan atas lusinan upaya yang dilakukan oleh pemerintah daerah di seluruh dunia.

\section{Memahami kemiskinan dan kesejahteraan lokal}

Untuk memahami karakteristik kemiskinan di daerahnya, pemerintah daerah harus menjawab pertanyaan-pertanyaan di bawah ini:

- Siapa yang miskin dan di manakah mereka berada?

- Apakah ciri khas kemiskinan tersebut?

- Apakah perbedaan-perbedaan lokal dalam memandang kemiskinan?

- Apakah penyebab kemiskinan tersebut dan bagaimana kondisinya?

- Apakah yang menjadi prioritas dari berbagai kelompok warga miskin?
- Apakah penghidupan atau strategi bertahan yang digunakan oleh warga miskin saat ini?

- Seberapa baik hasil dari upaya untuk mengurangi kemiskinan?

Untuk memahami kemiskinan diperlukan pengetahuan tentang warga miskin dan bagaimana aktivitas pembangunan dapat membantu mereka. Di dalamnya termasuk juga memahami bagaimana kondisi kemiskinan berubah. Pertanyaanpertanyaan ini harus selalu dikemukakan agar pemerintah daerah senantiasa memiliki pengetahuan yang terkini. Rumah tangga miskin seringkali cerdik dalam mengelola penghidupan yang bervariasi untuk menyikapi risiko, sehingga intervensi pembangunan harus dilakukan dengan hati-hati agar tidak merusak strategi kelangsungan hidup yang sudah berhasil ini dan tidak menimbulkan ketergantungan. Pengumpulan informasi tentang kemiskinan dapat menjadi bagian dari program pemantauan dan evaluasi. Pemetaan interaktif (Alat 1) dan pemantauan kesejahteraan rumah tangga (Alat 2 ) adalah contoh alat yang dapat digunakan untuk tujuan ini.

\section{Berkomunikasi dan berkoordinasi dengan warga miskin}

Salah satu tantangan terbesar bagi pemerintah daerah adalah meningkatkan komunikasi, interaksi dan koordinasi dengan warga miskin. Di banyak tempat, warga miskin adalah kelompok terakhir yang mendapatkan perhatian, karena pengaruh mereka terhadap politik seringkali kecil, hidup di kawasan yang sulit dijangkau atau menanggung prasangka atau diskriminasi atas dasar kesukuan, kelas atau gender.

Tetapi membangun kapabilitas warga miskin dapat menjadi landasan yang kuat untuk meraup keuntungan ekonomi dan politik di kemudian hari. Peningkatan komunikasi dan koordinasi dapat membantu pemerintah daerah dan warga miskin dalam mengembangkan saling pengertian dan pertalian yang konstruktif untuk mengambil tindakan bersama. 


\section{Kotak 4. Sulitnya menjadikan kemiskinan di Malinau sebagai prioritas}

Pada tahun 2004, Komite Pengentasan Kemiskinan dibentuk di Malinau untuk mengurangi jumlah penduduk miskin di kabupaten ini. Sesuai dengan petunjuk pemerintah pusat, komite ini diminta untuk membuat rencana pengentasan kemiskinan strategis, menajamkan program pemerintah kabupaten, dan memprioritaskan dana untuk pengentasan kemiskinan dalam APBD.

Komite ini tidak mengkoordinasikan program kemiskinan yang terpadu atau berpengaruh. Koordinasi antar sektor sulit dilakukan karena kurangnya dana dan kewenangan. Sedikit sekali anggota komite yang berpengalaman di bidang pengentasan kemiskinan. Rencana dan rekomendasi anggaran komite tidak terpadu dengan pengambilan keputusan kabupaten. Kebanyakan pejabat kabupaten menganggap komite ini tidak relevan. Kriteria kemiskinan dibuat oleh pemerintah daerah tanpa mempertimbangkan kondisi setempat di kabupaten-kabupaten berhutan.

Sementara itu, APBD kabupaten naik hingga 200\% antara 2001-2003. Dana dari pemerintah pusat menyumbang $69-70 \%$, dan pendapatan asli daerah 4-6\%. Sebagian besar anggaran kabupaten digunakan untuk membangun ibu kota

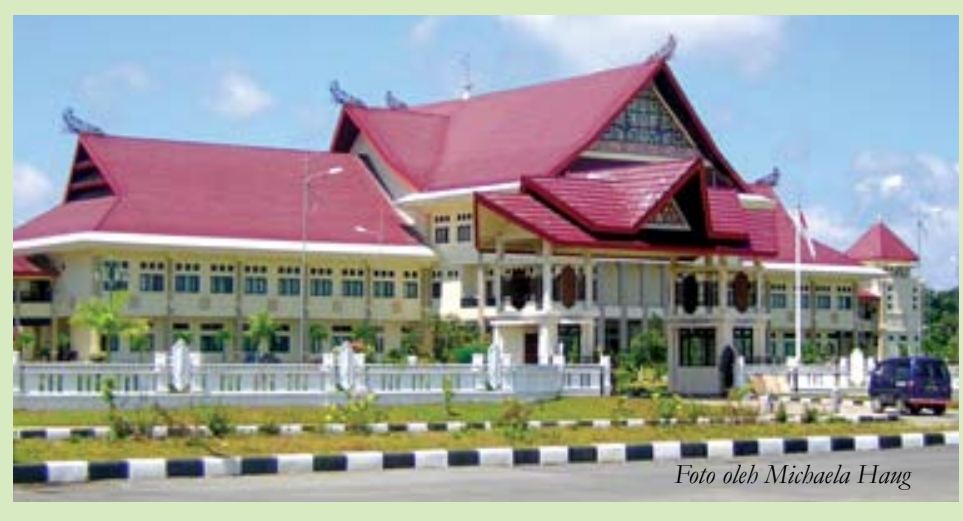
kabupaten baru, terutama membangun kantor-kantor pemerintah dan menyediakan fasilitas perumahan dan fasilitas pendukung bagi para pegawai negeri.

Pada tahun 2004, ketua Komite Pengentasan Kemiskinan mengajukan 28 program untuk mengatasi masalah kemiskinan yang dimasukkan ke dalam rencana strategis kabupaten. Tetapi programprogram ini tidak dimasukkan ke dalam anggaran.

Kantor Pemerintah Daerah di

Malinau, Kalimantan Timur

Diskusi terbuka dengan warga miskin harus sering dilakukan agar pemerintah daerah dapat lebih memahami prioritas masyarakat miskin. Alat evaluasi masyarakat terhadap program pemerintah (Alat 3) dan perencanaan berbasis skenario (Alat 4) merupakan contoh untuk melakukan hal ini.

Komunikasi yang baik menuntut komitmen untuk mengunjungi warga miskin di rumah mereka, sawah atau hutan. Orang mungkin akan lebih terbuka untuk menyampaikan pendapatnya jika mereka berada di komunitasnya sendiri, dibandingkan dengan di kantor pemerintah. Kehadiran secara fisik di tempat-tempat dimana warga miskin menjalani kehidupannya sehari-hari dapat membantu para pejabat menyaksikan langsung apa yang dialami oleh warga miskin.
Tindakan untuk memperkuat partisipasi dan representasi berbagai kelompok masyarakat miskin dan akuntabilitas di mata mereka merupakan modal penting untuk mendukung pandangan warga miskin terhadap pengambilan keputusan oleh pemerintah. Contoh tindakan tersebut antara lain mengadakan pertemuan di tempattempat yang terjangkau oleh warga miskin, melembagakan kotak suara untuk voting kebijakan, atau sekedar memberi tahu warga bahwa mereka dipersilakan untuk menyuarakan pendapatnya. Pemerintah daerah selanjutnya dapat bekerja bersama warga miskin dengan lebih baik untuk mengembangkan tindakan yang akan diambil. 
Upaya eksplisit harus dilakukan untuk merespons kebutuhan kelompok 'tak kentara', seperti perempuan, anak-anak, lanjut usia dan beberapa kelompok etnis yang secara khusus rentan untuk diabaikan dan dipinggirkan. Pada saat bersamaan, kehati-hatian perlu dikedepankan untuk menghindari pelekatan stigma atau perampasan kekuasaan kalangan lemah, yang dapat membekukan mereka ke dalam kategori 'miskin' secara permanen. Intervensi penanggulangan kemiskinan berpotensi memicu dinamika negatif antar subsub kelompok miskin jika tindakan yang dilakukan dirasa lebih memihak satu kelompok dibanding kelompok yang lain, misalnya lebih memihak kelompok perempuan dibanding lakilaki, atau satu etnis minoritas dibandingkan etnis lainnya.

\section{Mengambil tindakan yang menguntungkan warga miskin}

Pemerintah daerah dapat mempengaruhi kemiskinan melalui keputusan yang dibuatnya. Kesempatan untuk lebih tanggap terhadap kalangan miskin muncul setiap tahun pada proses perencanaan atau alokasi anggaran, serta pada bagaimana keputusan diimplementasikan. Kesempatan juga dapat muncul secara tak terduga. Jika pemerintah daerah mengumpulkan informasi dan menyimak para konstituennya, maka pemerintah daerah akan lebih mengetahui tindakan yang perlu diambil. Efektivitas juga mensyaratkan kegesitan untuk merespons kesempatan manakala kesempatan itu hadir.

Pemerintah daerah dapat menciptakan lingkungan pendukung yang memberi kebebasan dan kesempatan untuk memanfaatkan kapabilitas dan aset masyarakat sendiri dengan sebaik-baiknya. Mereka dapat menyediakan dukungan, memfasilitasi kerjasama antara para pemangku kepentingan dan mengurangi kerentanan. Tetapi pada saat bersamaan pemerintah daerah harus membidik peningkatan kesejahteraan yang berkelanjutan.

Untuk merespons kebutuhan masyarakat miskin, pemerintah daerah perlu menjadikan penanggulangan kemiskinan secara berkelanjutan sebagai prioritas dan menyadari bagaimana keputusan yang mereka ambil dapat mempengaruhi kesejahteraan masyarakat di wilayahnya. Apabila penanggulangan kemiskinan tidak dijadikan agenda utama, maka akan selalu ada tendensi untuk lebih memperhatikan kepentingan kalangan yang lebih berpengaruh.

Semua prinsip ini sama-sama pentingnya. Misalnya, meningkatkan panen sumber daya hutan dengan cara yang tidak berkesinambungan memang dapat memberi lebih banyak uang kepada masyarakat untuk jangka pendek, tetapi itu berarti menempatkan mereka pada risiko saat sumber pemasukan ini menghilang sementara mereka tidak mempunyai sarana untuk memperoleh penghasilan yang lebih besar. Contoh lain, upaya mengurangi kerentanan melalui bantuan pangan atau papan tidak akan mengurangi kemiskinan kronis, kecuali jika kesinambungan dan kesempatan juga menjadi perhatian.

Ada tindakan tertentu dari pemerintah daerah yang akan memberi imbalan yang lebih baik dibandingkan tindakan lainnya. Di Bolivia dan Indonesia, warga miskin akan merasakan manfaat setinggi-tingginya jika pemerintah daerah mendukung:

- Akses terhadap keuntungan dari panen kayu dan produk hutan lainnya

- Layanan kesehatan dan pendidikan

- Pengakuan hak-hak lahan bagi warga miskin

- Pembangunan infrastruktur

- Akses terhadap pekerjaan

- Komunikasi antar konstituen dan dengan pemerintah daerah.

Di banyak tempat, pemerintah daerah tidak menggunakan kesempatan untuk memanfaatkan sumber daya hutan untuk mengurangi kemiskinan. Pemerintah daerah harus mendukung pengelolaan sumber daya hutan yang bernilai untuk mengurangi kemiskinan. Mereka dapat melakukannya secara langsung melalui kebijakan pembangunan ekonomi lokal. Bahkan sekalipun pemerintah daerah tidak memiliki kewenangan langsung atas sumber daya hutan, mereka dapat memberi advokasi bagi masyarakat yang tinggal di kawasan hutan dan 
membantu mereka berhubungan dengan lembaga pemerintah yang lain. Misalnya, pejabat pemerintah yang bertanggung jawab atas sumber daya hutan, yang mungkin mengabaikan permintaan dari sebuah desa miskin, akan lebih mungkin untuk merespons pertemuan yang diadakan oleh lembaga pemerintah setempat. Kehati-hatian harus dikedepankan agar pembangunan ekonomi dan aktivitas pengelolaan hutan sejalan dengan sasaran pengurangan kemiskinan.

Cara-cara pengelolaan hutan yang dapat memberi manfaat bagi warga miskin antara lain meningkatkan akses dan kendali warga terhadap sumber daya hutan, mendidik warga miskin tentang hak-hak mereka atas hutan, melindungi akses hutan warga miskin, menciptakan lingkungan pendukung untuk mengembangkan usaha dan konservasi hutan, meningkatkan pemerataan manfaat hutan bagi masyarakat miskin, dan mendukung pembangunan pasar hilir.

Dari sudut pandang regulasi, pemerintah daerah dapat menjamin keselamatan kerja dalam operasi kehutanan, menegakkan hak milik dan mempengaruhi pemerataan manfaat. Pemerintah daerah dapat melakukan lobi untuk mengkoordinasikan regulasi secara lintas sektoral, khususnya antara sektor kehutanan, pembangunan ekonomi, regulasi pengurangan kemiskinan dan lingkungan.

Pemerintah daerah dapat mendukung pilihan jenis, jumlah dan produk hutan yang akan dikelola yang lebih sesuai dengan kebutuhan dan pilihan masyarakat miskin.

Tetapi tidak boleh ada asumsi bahwa hutan merupakan sektor paling penting yang harus dikembangkan. Dalam beberapa kasus, bentuk-bentuk pemanfaatan lahan yang lebih intensif, pekerjaan dan layanan-layanan lain bisa menjadi cara yang lebih efektif untuk menghadapi kemiskinan. Ketergantungan terhadap hutan dapat menjadi jerat kemiskinan apabila sumber penghidupan ini tidak memadai untuk membuat masyarakat mengumpulkan surplus atau memiliki jaminan ekonomi yang cukup untuk memilih penghidupan alternatif.

Pemerintah daerah tidak boleh hanya memberi keuntungan bagi warga yang sudah menikmati posisi ekonomi dan politik

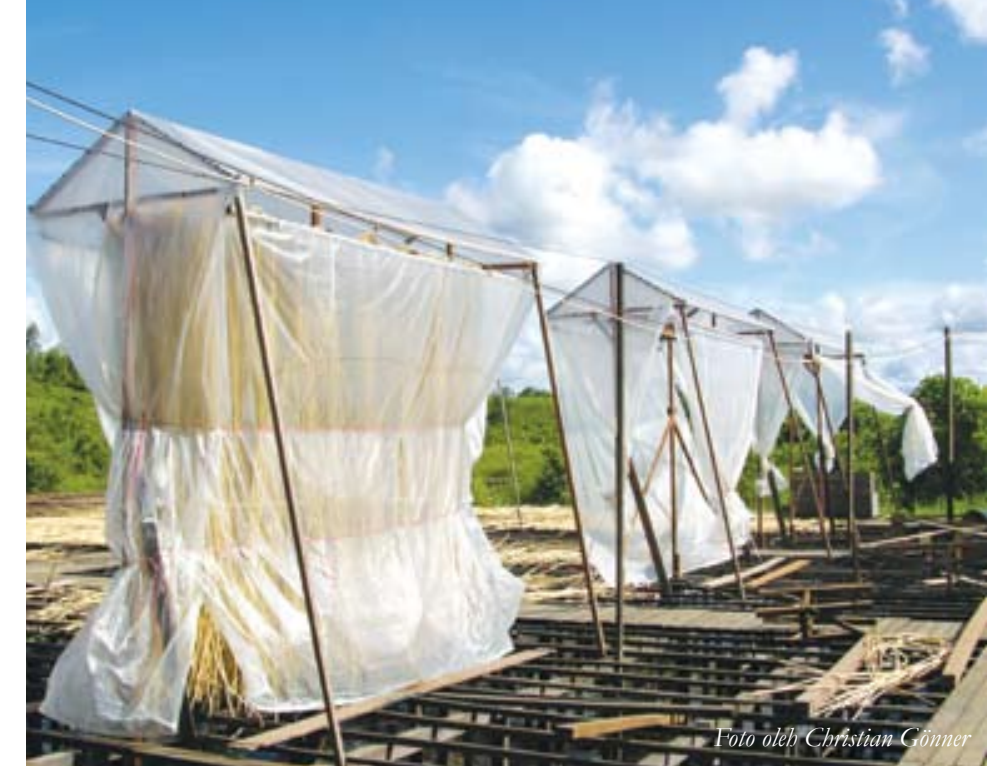

Pemerintah daerah dapat mempromosikan proyekproyek yang memperkuat sektor kehutanan, seperti pengolahan rotan

yang kuat. Mencegah mengalirnya keuntungan kepada kalangan elit dan melindungi hak-hak warga miskin merupakan tindakan yang sangat penting. Tindakan transparan yang menyoroti keuntungan berkelebihan bagi kalangan elit atau praktikpraktik ilegal harus dikedepankan.

Pemantauan dampak dari tindakan ini sangat penting dilakukan untuk menyesuaikan dan meningkatkan upaya-upaya di masa mendatang.

\section{Mendapatkan keseimbangan antara berbagai aspek kesejahteraan}

Pemerintah daerah dapat mempengaruhi berbagai aspek kemiskinan. Diperlukan keseimbangan antara lingkungan alam, ekonomi, sosial dan politik (lihat 'Apa sajakah dimensi kemiskinan dan kesejahteraan?' di atas) dan kondisi inti yang mempengaruhi kesejahteraan subjektif masyarakat. Kotak 5 di menampilkan beberapa contoh tentang bagaimana pemerintah daerah dapat mempengaruhi kesejahteraan pada berbagai bidang ini. 
Kotak 5. Lingkungan bagi pemerintah daerah untuk meningkatkan kesejahteraan dan mengurangi kemiskinan

\begin{tabular}{|c|c|c|c|}
\hline Lingkungan Alam & Lingkungan Ekonomi & Lingkungan Sosial & Lingkungan Politik \\
\hline $\begin{array}{l}\text { Memberi dan } \\
\text { menegakkan } \\
\text { kerangka hukum } \\
\text { untuk pemanfaatan } \\
\text { sumber daya hutan } \\
\text { yang berkelanjutan } \\
\text { - Mendukung upaya- } \\
\text { upaya konservasi } \\
\text { - Menengahi konflik } \\
\text { antara aturan adat } \\
\text { dan sumber daya } \\
\text { hukum. }\end{array}$ & $\begin{array}{l}\text { - Menciptakan } \\
\text { lingkungan } \\
\text { pendukung yang } \\
\text { stabil untuk } \\
\text { pembangunan } \\
\text { ekonomi } \\
\text { - Menarik investor } \\
\text { - Mendukung usaha } \\
\text { kecil dan menengah } \\
\text { - Mempermudah } \\
\text { akses terhadap } \\
\text { modal dan pasar. }\end{array}$ & $\begin{array}{l}\text { - Mengidentifikasi dan } \\
\text { berkomunikasi dengan } \\
\text { kelompok sosial yang } \\
\text { sesuai } \\
\text { - } \text { Menawarkan mediasi } \\
\text { konflik dan sengketa } \\
\text { antardesa atau antara } \\
\text { desa dan perusahaan } \\
\text { - Mendorong kohesi } \\
\text { sosial } \\
\text { Mendorong kolaborasi } \\
\text { antara kelompok } \\
\text { kepentingan setempat. }\end{array}$ & $\begin{array}{l}\text { - Memberdayakan desa dan } \\
\text { kelompok yang rentan } \\
\text { atau marjinal melalui } \\
\text { partisipasi yang lebih } \\
\text { besar } \\
\text { - Membangun komunikasi } \\
\text { dua arah yang tulus } \\
\text { dengan warga miskin } \\
\text { - Memberi dan menegakkan } \\
\text { perlindungan hukum dan } \\
\text { keamanan } \\
\text { - Meningkatkan transparansi } \\
\text { dan melawan korupsi. }\end{array}$ \\
\hline
\end{tabular}

Intervensi pembangunan sering melibatkan 'imbanganimbangan' dimana pencapaian pada satu lingkungan dilakukan dengan menimbulkan kerugian pada lingkungan yang lain. Misalnya, pengubahan hutan menjadi perkebunan kelapa sawit menghasilkan pendapatan yang signifikan di Indonesia, tetapi juga merusak hutan dan meningkatkan kerentanan dan menurunkan jaminan pangan bagi rumah tangga miskin yang bergantung pada hutan.

Banyak pemerintah daerah yang cepat berfokus pada sektor ekonomi dan kurang memberi perhatian pada dimensidimensi lain, karena dimensi-dimensi tersebut mungkin tidak kentara atau pemerintah daerah kurang memiliki pengetahuan tentang bagaimana menanganinya. Tetapi, untuk mencapai pembangunan yang berkelanjutan, kesemua lingkungan NESP diperlukan dan dapat saling memperkuat.
Untuk pemerintah daerah yang baru dibentuk, kapasitas pada keempat bidang ini perlu dibangun. Meskipun banyak pemerintah daerah yang masih berjuang dengan mandat baru mereka, tetapi ada tanda-tanda positif bahwa desentralisasi dapat menghadirkan manfaat bagi warga miskin dan meningkatkan kesejahteraan. Mendekatkan diri dengan warga yang membutuhkan, mendengarkan keluh-kesah mereka, dan menganggap mereka sebagai mitra dalam pembangunan adalah langkah pertama. Selain itu, kapasitas dan profesionalisme pemerintah daerah perlu ditingkatkan, demikian juga dengan mekanisme untuk menangani kemiskinan pada semua bidang melalui cara yang berkelanjutan. 


\section{Referensi dan bacaan lebih lanjut}

Batterbury, S. and Fernando, J. 2006 Rescaling governance and the impacts of political and environmental decentralization: an introduction. World Development 34(11):1851-1863.

de Jong, W., Ruiz, S. and Becker, M. 2006 Conflicts on the way to communal forest management in northern Bolivia. Forest Policy and Economics 8: 447-457.

Gottwald, C. 2006 Capacities of rural forest-dependent communities in the northern Bolivian Amazon in times of legal reforms. Freiburger Schriften zur Forst- und Umweltpolitik Band 11. Remagen-Oberwinter (Verlag Dr. Kessel), Jerman.

Gregersen, H.M., Contreras-Hermosilla, A., White, A. and Phillips, L. 2005 Forest governance in federal systems: an overview of experiences and implications for decentralization. In: Colfer, C.J.P. and Capistrano, D. (eds.) The politics of decentralization, forests, power and people, Earthscan, London.

Jütting, J., Kauffmann, C., Mc Donnell, I., Osterrieder, H., Pinaud, N. and Wegner, L. 2004 Decentralisation and poverty in developing countries: exploring the impact. OECD Development Centre. Working Paper No. 236. Paris.

Ribot, J.C. and Larson, A.M. (eds.) 2005 Democratic decentralisation through a natural resource lens. Routledge, Oxon, UK. 260p.

Ruiz, S.A. 2005 Institutional change and social conflicts over forest use in the northern Bolivian Amazon. Freiburger Schriften zur Forst- und Umweltpolitik Band 10. RemagenOberwinter (Verlag Dr. Kessel), Freiburg, Jerman.
Soetarto, E., Sitorus, M.T.F. and Napiri, M.Y. 2001 Decentralisation of administration, policy making and forest management in Ketapang district, West Kalimantan. Case Studies on Decentralisation and Forests in Indonesia Case study No. 8. CIFOR, Bogor, Indonesia. 55p.

Wollenberg, E., Moeliono, M., Limberg, G., Iwan, R., Rhee, S. and Sudana, M. 2006. Between state and society: local governance of forests in Malinau, Indonesia. Forest Policy and Economics 8(4): 421-433. 


\section{Bagaimana hutan mempengaruhi kesejahteraan?}

Pemerintah daerah yang berupaya mengurangi kemiskinan di daerah hutan menghadapi tantangan yang berbeda dengan mereka yang berada di daerah pertanian atau perkotaan. Hutan dapat menciptakan peluang unik untuk mengurangi kemiskinan, dan dapat pula menghadirkan kondisi yang menjebak masyarakat di dalam kemiskinan.

Jalinan antara hutan dan kemiskinan bervariasi bergantung pada sejumlah faktor, termasuk tingkat keterpencilan hutan, paduan sumber daya yang ditemukan di hutan itu, dan bagaimana masyarakat setempat berinteraksi dengan sumber daya tersebut. Jalinan dapat menjadi kompleks. Misalnya, di Pando, banyak keluarga menikmati pendapatan per kapita ratarata yang tergolong sebagai salah satu yang tertinggi di negara tersebut, karena kacang Brazil yang dipanen dari hutan alam dapat diperdagangkan dengan sangat menguntungkan. Tetapi mereka juga menghadapi kesulitan besar karena desa mereka yang terpencil sangat sulit mengakses layanan kesehatan dan pendidikan.

Pemerintah daerah harus memahami peran yang dimainkan hutan bagi penghidupan warga pedesaan. Dengan demikian, mereka dapat berupaya mengurangi kemiskinan melalui cara-cara yang merupakan solusi dari masalah yang dihadapi masyarakat hutan, tanpa menghadirkan dampak negatif terhadap sumber daya yang mendukung penghidupan mereka.

\section{Apakah kemiskinan pada masyarakat hutan?}

Kemiskinan bersifat multidimensi. Di sini perlu dipertimbangkan aspek-aspek kemiskinan apa saja yang paling relevan dalam konteks masyarakat hutan. Penghidupan berbasis hutan menghadirkan peluang sekaligus batasan. Lingkungan ini sering memiliki infrastruktur yang buruk dan layanan yang terbatas, tetapi mereka tidak menghadapi masalah kepadatan penduduk, kekerasan dan polusi sebagaimana yang dihadapi oleh masyarakat kota. Kesejahteraan subjektif masyarakat hutan dapat sangat dipengaruhi oleh ikatan emosional dan spiritual mereka dengan lanskap hutan. Faktor ini bervariasi dari satu tempat ke tempat yang lain, tetapi pada bagian ini kita dapat menyinggung beberapa isu utama yang mendefinisikan kondisi kemiskinan di kawasan berhutan.

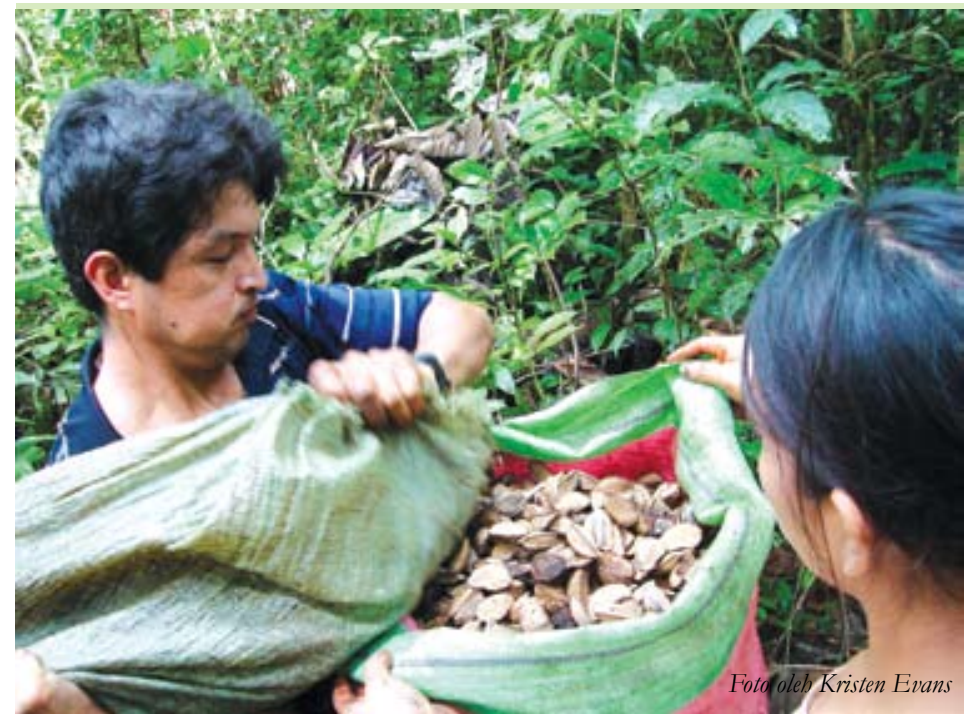

Masyarakat di Pando mendapatkan sebagian besar penghasilan mereka dari panen kacang Brazil dari hutan alam. 
Upaya memahami karakteristik kemiskinan dan kesejahteraan di hutan diperumit dengan adanya keanekaragaman hayati yang ditemukan di hutan, variasi di dalam dan di antara masyarakat hutan, dan perbedaan hak dan kesempatan mereka untuk memanfaatkan sumber daya hutan. Banyak kebutuhan dasar dapat dipenuhi dengan produk hutan seperti makanan, obat-obatan, air bersih, keperluan keagamaan, bahan bakar dan bahan bangunan-yang memberi suatu tingkat keterpenuhan diri. Pada saat bersamaan, lokasi masyarakat hutan yang umumnya terpencil membuat mereka memiliki akses yang buruk terhadap layanan-layanan dasar seperti pendidikan yang bermutu dan perawatan kesehatan yang baik.

Sumber daya hutan juga dapat menjadi sumber penghasilan dari aneka macam produknya, termasuk kayu, kacangkacangan, kulit kayu, buah-buahan, daging dan tanaman obat. Keanekaragaman ini membuat keluarga yang tinggal di kawasan ini dapat menghindari risiko dengan berganti-ganti produk saat harga berfluktuasi atau musim berubah. Tetapi masyarakat hutan sering menghadapi kendala besar untuk menaikkan pendapatan tunai mereka dengan mengandalkan produk hutan, dan kesejahteraan moneter mereka cenderung rendah. Beberapa produk hutan menyebar jarang di atas bentang hutan yang luas, sehingga diperlukan banyak waktu dan upaya untuk memanennya, yang berarti keuntungan yang diperoleh sering lebih rendah dibandingkan tenaga yang dikeluarkan. Masyarakat yang tinggal di lingkungan hutan biasanya kekurangan informasi tentang harga dan permintaan pasar, dan jika mereka mencoba mengakses pasar, biaya transportasi sangat menyita pendapatan yang diperoleh. Karena risiko dan tingginya biaya untuk berpartisipasi di pasar, mereka sangat mengandalkan pedagang untuk menjual produk pertanian dan hutannya. Para pedagang ini menikmati keuntungan yang sangat besar. Masyarakat yang tinggal di dekat hutan juga memiliki akses yang lebih kecil terhadap pekerjaan berupah. Kadang-kadang memang tersedia pekerjaan seperti menebang pohon, memanen produk-produk hutan, membuka peternakan di area yang sudah dibersihkan atau pertambangan, tetapi biasanya pekerjaan ini hanya berjangka pendek dan bersifat musiman.

Dimensi sosial seperti kerjasama, rasa saling percaya dan tingkat konflik yang rendah-tiga indikator yang oleh masyarakat hutan sering dianggap mempengaruhi rasa sejahtera mereka-dapat bervariasi antara komunitas hutan yang satu dengan lainnya. Dimensi ini bervariasi sebagai akibat dari: kekuatan jaringan sosial, seperti yang didasarkan pada kekerabatan atau hubungan pasar; tingkat homogenitas etnis, agama, sosio-ekonomi dan politik; kekuatan hierarki dan lembaga pemerintahan daerah; tingkat persaingan di dalam masyarakat untuk mendapatkan sumber daya; dan tekanan sosial, seperti yang terkait dengan perubahan tapal batas. Di beberapa tempat, keterpencilan dan hubungan yang buruk dengan masyarakat sekitar menuntut tingkat kebergantungan diri yang lebih besar. Pada kasus yang lain, individu mungkin sangat bergantung pada individu lain untuk penghidupan dan kesejahteraan mereka, sehingga tercipta kohesi dan kerjasama sosial yang lebih kuat. Rasa saling percaya dan mediasi konflik menjadi kebutuhan untuk kelangsungan hidup. Bila kepadatan penduduk rendah, maka kemampuan masyarakat untuk memecah dan berpindah ke lokasi baru saat muncul konflik dapat memberi katup pengaman untuk meredakan ketegangan.

Jaringan sosial yang stabil tidak mudah dibentuk. Keterpencilan sering menjadi kendala untuk membangun jalinan yang kuat dengan warga lain, sehingga peluang untuk berinteraksi menjadi berkurang. Bagi masyarakat yang tinggal di pemukiman yang memencar, untuk berkumpul ke dalam kelompok yang efektif bisa jadi mahal dan sulit, dan hal ini semakin melemahkan organisasi politik di kalangan masyarakat hutan. Saat lahan atau sumber daya hutan tersedia, konflik dalam masyarakat atau dengan pihak luar bisa meningkat. Di Kalimantan Timur, konflik perebutan kayu gaharu yang mahal menimbulkan dampak negatif yang serius pada kohesi sosial di desa-desa. Di Pando, hak milik yang diperselisihkan atau tidak diatur dengan baik, yang diperparah dengan tingginya 
permintaan kacang Brasil, kadang-kadang berujung pada kekerasan.

Masyarakat di kawasan terpencil sering tersisihkan secara politik, sehingga, dibandingkan dengan warga yang tinggal di kawasan perkotaan yang lebih terjangkau, mereka ini tidak beruntung. Keterpencilan dari pusat-pusat perpolitikan mengurangi peluang mereka untuk berpartisipasi dalam pertemuan-pertemuan, melobi para pembuat keputusan, atau mematuhi persyaratan administratif yang mempengaruhi kehidupan sehari-hari mereka. Misalnya, di Kalimantan, masyarakat dari desa-desa terpencil sering tidak dapat menghadiri pertemuan penting karena pemberitahuannya baru sampai setelah pertemuan itu sendiri selesai. Meskipun marginalisasi ini merupakan masalah, tetapi dalam beberapa kasus, warga miskin memang sengaja mencari tempat yang terpencil untuk menghindari represi atau diskriminasi politik.

Kepemilikan lahan yang tidak jelas memperlemah pengaruh politik masyarakat hutan dan mengancam penghidupan mereka. Sudah menjadi pengetahuan umum bahwa masyarakat hutan sering tidak memiliki hak legal atas lahan yang telah mereka tempati turun-temurun. Mereka dianggap penghuni liar tanpa lahan dan, karenanya, tidak memiliki hak politik. Hak untuk mengumpulkan dan menjual produk hutan sangat mempengaruhi jenis pendapatan yang tersedia bagi warga miskin. Di banyak tempat, undang-undang nasional hanya mengizinkan masyarakat setempat untuk memanen produk hutan yang mereka makan. Karena masyarakat hutan tidak mempunyai hak kepemilikan formal, mereka kadang terdesak untuk menjual produk hutan, seperti kayu, secara sembunyisembunyi di pasar informal. Dengan cara ini, kemampuan mereka untuk merundingkan harga yang wajar menjadi sangat terbatas dan, ketika ditipu, mereka tidak bisa mendapatkan bantuan hukum. Jika hak-hak kepemilikan ini dipermasalahkan, mereka dapat kehilangan sumber daya utama ke pemangku kepentingan yang lebih kuat, khususnya jika pasar bersifat terbuka dan harga-harga meningkat.

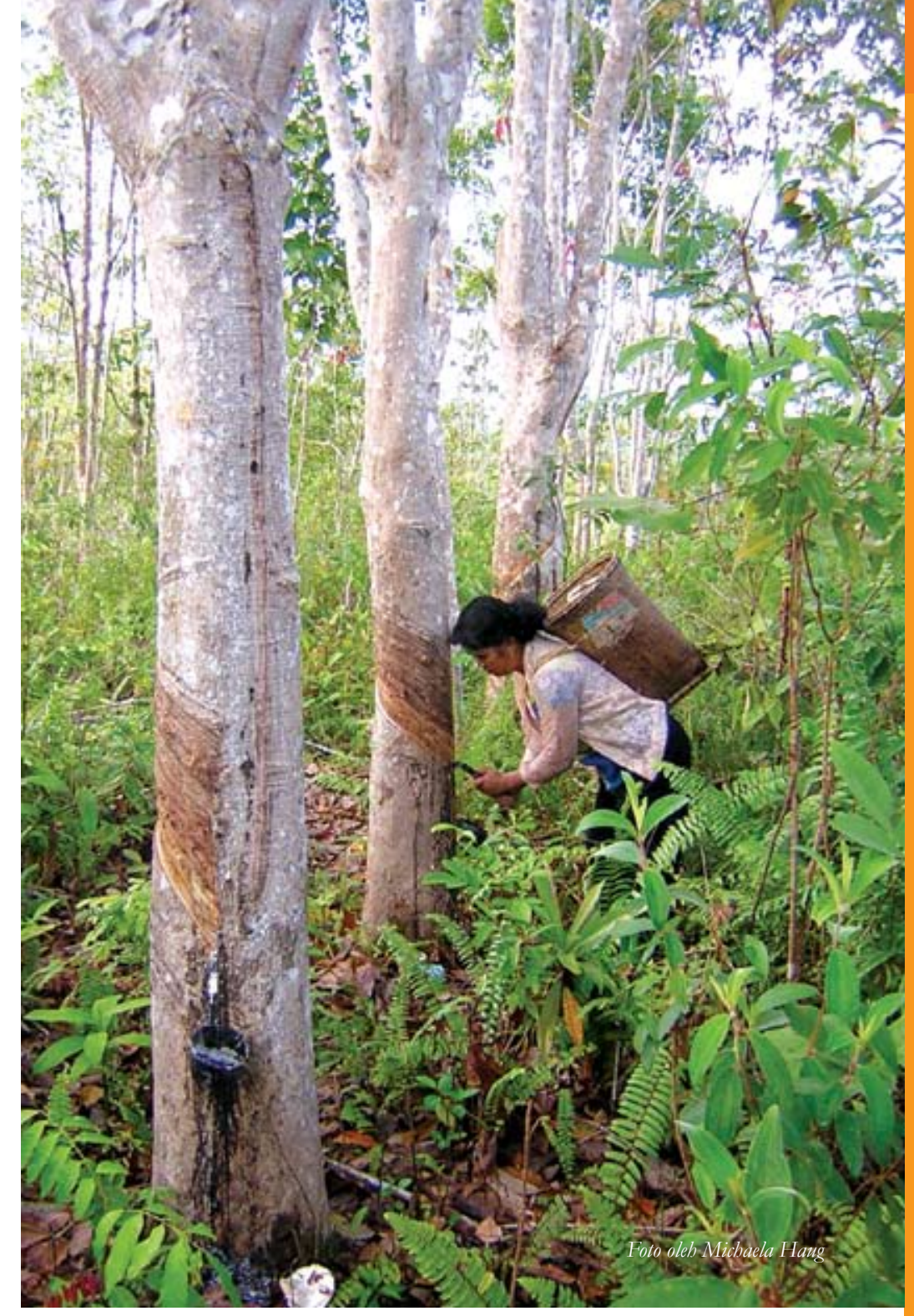

$26 \mid$ menuju kesejahteraan dalam masyarakat hutan 


\section{Apakah hutan merupakan jaring pengaman, jebakan kemiskinan atau jalan keluar?}

Apakah peran hutan dalam membantu masyarakat untuk keluar dari kemiskinan? Melalui perdebatan berhasil diidentifikasi bahwa hutan memainkan peran yang bermacammacam. Bergantung pada situasinya, hutan dapat menjadi jaring pengaman atau jebakan kemiskinan. Sebagian besar pembahasan yang dirangkum di sini menekankan kaitan antara hutan dan lingkungan ekonomi.

Hutan menjadi jaring pengaman bagi kalangan lemah di saat-saat sulit, seperti kemarau atau jatuhnya harga produk pertanian. Masyarakat di kawasan hutan untuk sementara dapat menggunakan produk hutan alternatif untuk memenuhi kebutuhan daruratnya saat sumber daya utama dalam sistem penghidupannya tidak dapat diandalkan. Fungsi jaring pengaman ini dapat memberi penghidupan (misalnya, dengan menyumbang umbi-umbian, daging hewan, sayur-mayur dan obat-obatan) atau pendapatan tunai. Daya tahan jaring pengaman ini terbatas; meskipun hutan dapat memberi periode buffer (penyangga) untuk melemahkan dampak bencana, masyarakat kemungkinan tidak dapat mengandalkan hutan untuk waktu yang lama dan harus cepat-cepat menemukan alternatif lain.

Sebaliknya, dalam kondisi tertentu, ketergantungan pada sumber daya hutan dapat juga dipandang sebagai jebakan kemiskinan. Ini dapat terjadi bila masyarakat miskin didesak ke dalam kawasan hutan marjinal dimana produk-produk hutan yang tersedia untuk mereka hanya memiliki nilai yang rendah, atau saat mereka tidak memiliki kapasitas, aset atau hak untuk memanfaatkan sumber daya yang ada, sehingga sebagai gantinya mereka memilih strategi yang memungkinkan mereka untuk bertahan hidup dalam jangka pendek, tetapi yang untuk jangka panjang semakin menyusutkan sumber daya tersebut. Hasilnya adalah spiral menurun dari kerusakan sumber daya yang cepat dan meningkatnya kemiskinan.

Aktivitas terkait hutan dapat memberi peluang, atau jalan keluar, bagi masyarakat miskin. Kayu, misalnya, dapat memberi pendapatan tunai yang signifikan, meskipun itu baru bisa dicapai jika keterbatasan akses pasar, ketidakjelasan hak miliki dan jeratan kalangan elit bisa diatasi. Ini tidak berarti menjadikan hutan segala-galanya, karena begitu masyarakat ini mulai mendapatkan penghasilan yang lebih tinggi, mereka mungkin tergiur untuk membuka hutan, dan lebih memilih investasi pertanian dibandingkan penghidupan berbasis hutan. Strategistrategi lain dapat dicoba, misalnya pengambilan produk hutan non-kayu, seperti kacang Brasil, rotan dan karet alam, yang memberi pendapatan yang relatif baik tanpa merusak basis sumber daya. Di masa depan, bisa jadi layanan lingkungan memberikan peluang-peluang yang menarik bagi masyarakat yang berhasil memelihara lanskap hutan alamnya.

\section{Referensi dan bacaan lebih lanjut}

Barr, C., Wollenberg, E., Limberg, G., Anau, N., Iwan, R., Sudana, I.M., Moeliono, M. and Djogo, T. 2001 The impacts of decentralisation on forests and forest-dependent communities in Malinau district, East Kalimantan. Case Studies on Decentralisation and Forests in Indonesia Case Study No. 3. CIFOR, Bogor, Indonesia. 48p.

Meijaard, E., Sheil, D., Nasi, R., Augeri, D., Rosenbaum, B., Iskandar, D., Setyawati, T., Lammertink, A., Rachmatika, I., Wong, A. et al. 2005 Life after logging: reconciling wildlife conservation and production forestry in Indonesian Borneo. CIFOR and UNESCO, Bogor, Indonesia. 
Obidzinski, K. and Barr, C. 2003 The effects decentralisation on forests and forest industries in Berau district, East Kalimantan. Case Studies on Decentralisation and Forests in Indonesia Case Study No. 9. CIFOR, Bogor, Indonesia. 33p.

Ribot, J.C., Agrawal, A. and Larson, A.M. 2006 Recentralizing while decentralizing: how national governments reappropriate forest resources. World Development 34(11): 1864-1886.

Shackleton, S., Campbell, B.M., Wollenberg, E. and Edmunds, D. 2002 Devolution and community-based natural resource management: creating space for local people to participate and benefit? Natural Resources Perspectives (ODI) 76: 1-6. (Tersedia di: http://www.odi.org.uk/ $\mathrm{nrp} / 76 . \mathrm{pdf}$.)

Sunderlin, W.D., Angelsen, A., Belcher, B., Burgers, P., Nasi, R., Santoso. L. and Wunder, S. 2005 Livelihoods, forests and conservation in developing countries: an overview. Dalam: World Development 33(9): 1383-1402.

USAID (United States Agency for International Development) 2006 Issues in poverty reduction and natural resource management. USAID, USA. (Tersedia di: http://www. usaid.gov/our_work/agriculture/landmanagement/ poverty/pubs/poverty_nrm_report.pdf.)

Wollenberg, E., Belcher, B., Sheil, D., Dewi, S. and Moeliono, M. 2004 Why are forest areas relevant to reducing poverty in Indonesia? Governance Brief No. 4. CIFOR, Bogor, Indonesia. (Tersedia di: http: //www.cifor.cgiar. org/publications/pdf_files/govbrief/GovBrief0404.pdf.) 
Bagian I telah memaparkan beberapa gagasan tentang kemiskinan dan kesejahteraan dan hubungannya dengan desentralisasi di kawasan hutan. Pemikiran kritis tentang kemiskinan memang diperlukan, tetapi itu saja tidak cukup. Praktisi pembangunan dan khususnya para pengambil keputusan di pemerintah daerah memerlukan lebih dari sekedar konsep teoritis. Mereka membutuhkan panduan praktis untuk meningkatkan strategi pengurangan kemiskinan dan menjadikan program pembangunan mereka lebih efektif. Bagian II buku panduan ini adalah tanggapan atas kebutuhan ini. Dibangun di atas konsep yang dijelaskan dalam Bagian 1 ini.

Bagian II memaparkan empat alat praktis yang telah sukses diuji di lapangan. Deskripsi dari alat-alat ini dimaksudkan untuk mengilhami pemerintah daerah dalam upayanya untuk mengurangi kemiskinan dan meningkatkan kesejahteraan para konstituennya.

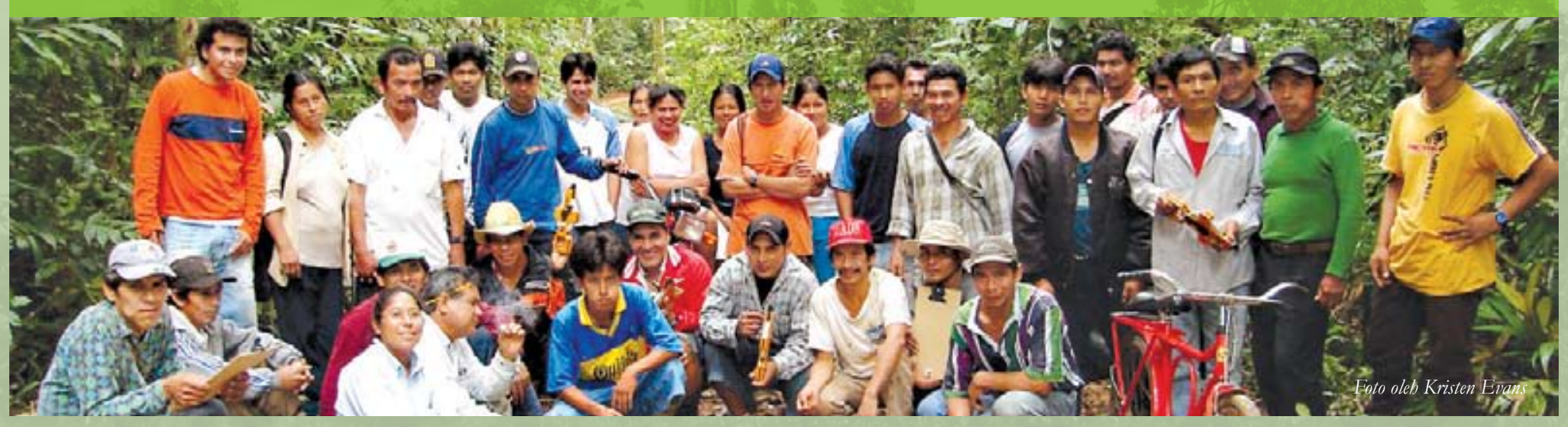




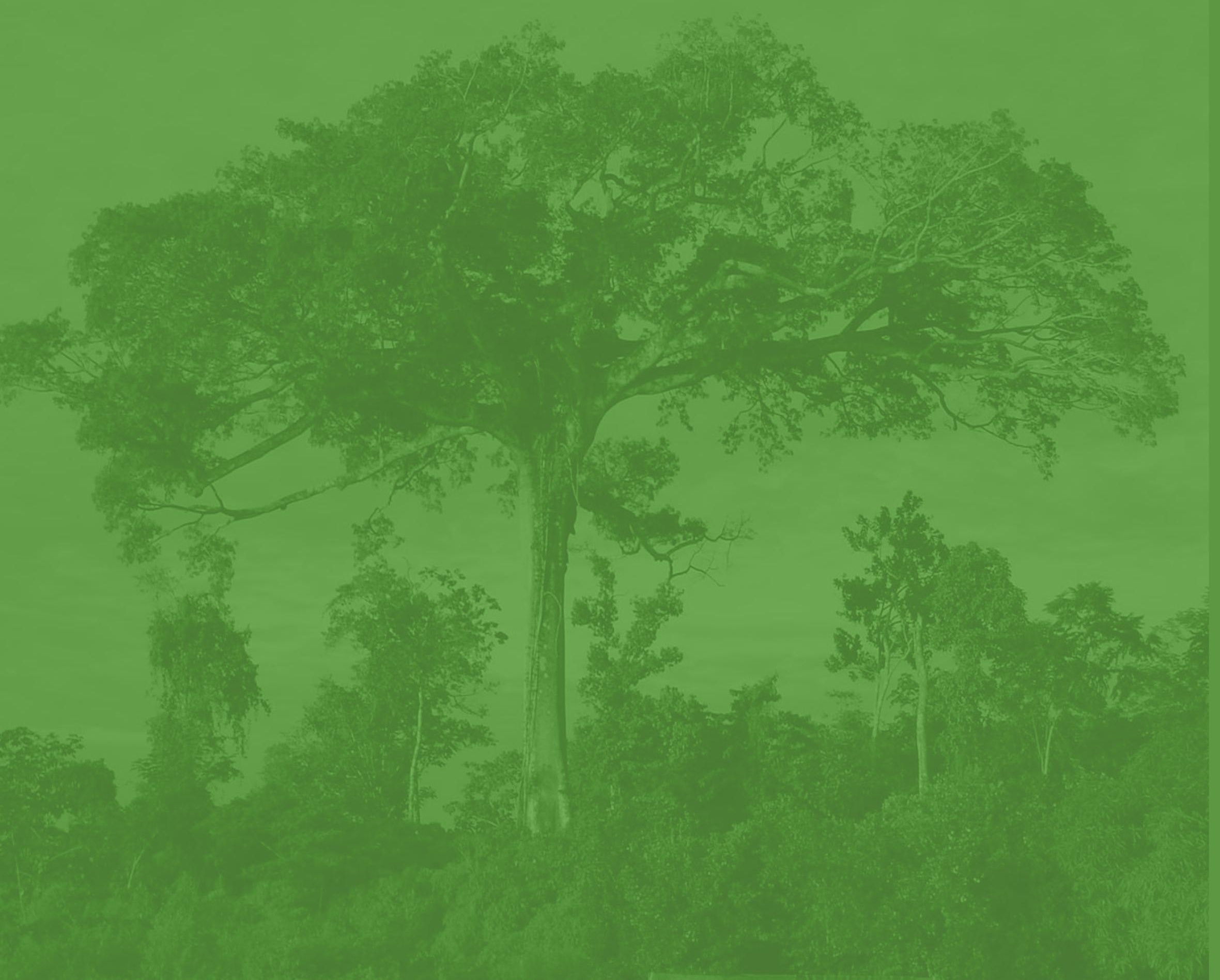




\section{Bagian II.}

\section{Alat-alat}

Pemantauan dan Perencanaan

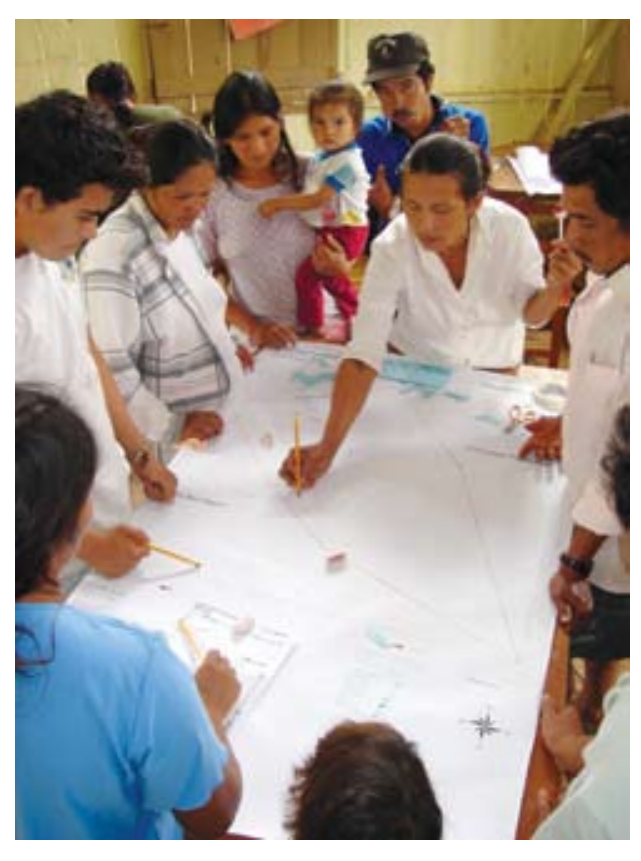


Mendukung siklus pengambilan keputusan pemerintah
daerah

Dibanding pemerintah pusat, pemerintah daerah lebih dekat dengan masyarakat miskin. Tetapi ini tidak berarti bahwa pemerintah daerah selalu berhasil mengurangi kemiskinan; mungkin mereka memiliki kemauan untuk itu, tetapi kekurangan sumber daya, kapasitas atau mandat politik untuk melakukan kemauan itu secara efektif.

Terlepas dari kendala-kendala itu, ada sebuah langkah penting yang dapat diambil pemerintah daerah untuk mengurangi kemiskinan: mereka dapat secara langsung melibatkan masyarakat miskin dalam pengambilan keputusan pemerintah.

Gambar 4 menunjukkan contoh sederhana dari siklus pengambilan keputusan pemerintah daerah. Model ini mencerminkan bagaimana keputusan idealnya dibuat di Bolivia dan Indonesia.

Gambar 4 juga menunjukkan bagaimana keempat alat dalam buku panduan ini dapat berguna dalam siklus tersebut. Sebagian alat dapat digunakan untuk meningkatkan perencanaan partisipatif dengan membantu masyarakat mengidentifikasi dan memprioritaskan tuntutan mereka, sementara alat lainnya dapat digunakan untuk membantu pemerintah daerah dalam memantau atau mengevaluasi upaya penanggulangan kemiskinan. Alat-alat ini dapat memperkuat siklus pengambilan keputusan dengan menyediakan informasi baru dan peluang tindakan pada titik-titik awal strategis pada siklus tadi. Keempatnya juga menyediakan mekanisme untuk meningkatkan partisipasi masyarakat.

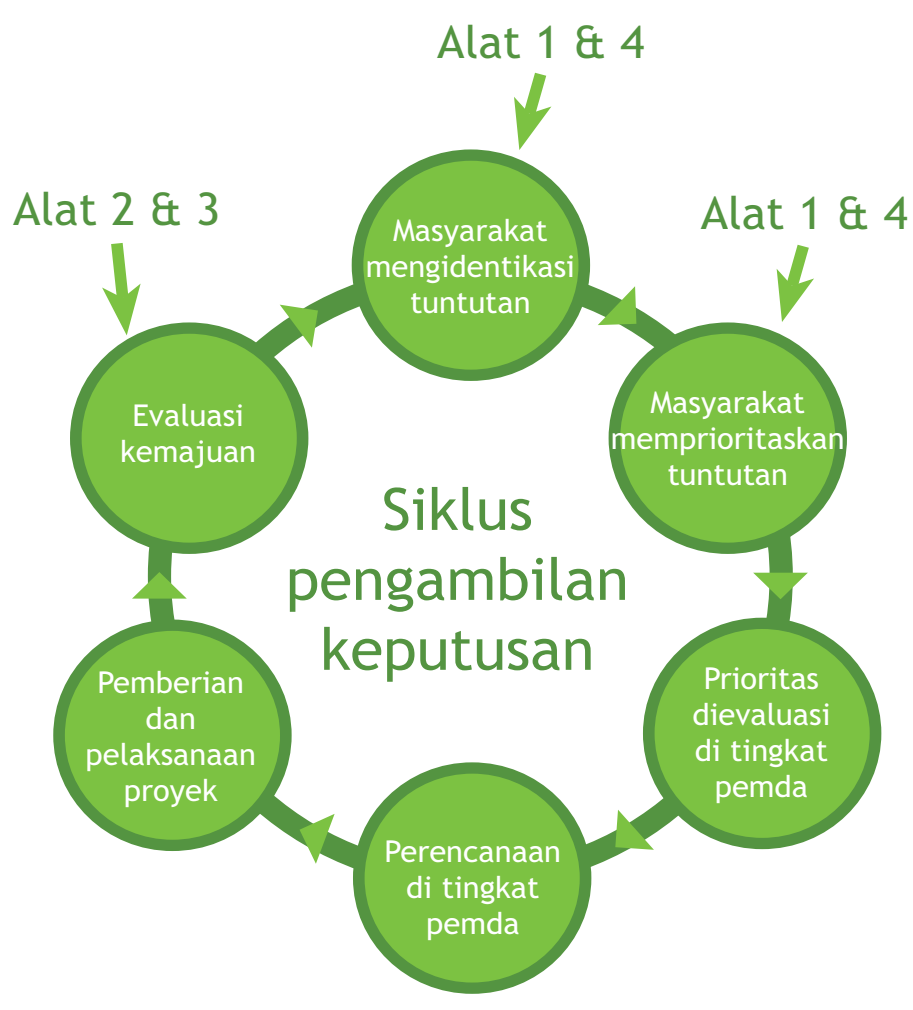

Gambar 4. Siklus pengambilan keputusan. 


\section{Pemantauan}

\author{
Apakah pemantauan \\ itu?
}

Pemantauan adalah pengumpulan dan analisis informasi secara sistematis untuk mengukur apakah sesuatu mengalami perubahan. Pemantauan adalah fungsi utama dalam pemerintahan dan merupakan bagian penting dari proses belajar bagi pemerintah daerah yang memikul tanggung jawab dan sumber daya baru dalam skema desentralisasi. Dengan informasi yang diperoleh melalui pemantauan, pemerintah daerah dapat menganalisa apakah program-programnya berjalan dengan baik dan menentukan cara meningkatkannya. Pemerintah daerah dapat belajar dari keberhasilan dan kegagalan yang dialami.

Pemantauan dapat membantu pemerintah daerah memahami apakah proses-proses baru dalam pemerintahan bersifat partisipatif. Misalnya, pemantauan dapat menjawab pertanyaan-pertanyaan seperti:

- Apakah pemimpin masyarakat memberi kesempatan terhadap semua konstituennya untuk bertanya sebelum mengajukan suatu proyek?

- Apakah partisipasi masyarakat dalam pertemuan anggaran tahunan meningkat? Siapa yang berpartisipasi?

Dengan pemantauan, pejabat pemerintah daerah juga dapat memahami kondisi yang

\section{Kotak 6. Indikator harus diukur lebih dari sekali}

Bayangkan seorang petugas kesehatan yang menimbang seorang anak tanpa memiliki informasi lain tentang anak itu atau tanpa pernah ketemu dengannya sebelumnya. Tentu akan sulit bagi petugas tersebut untuk banyak menyimpulkan tentang pertumbuhan si anak. Tetapi jika petugas tadi memiliki catatan dari observasi yang sama yang dilakukan berulang-ulang pada interval yang teratur selama beberapa bulan, maka akan mungkin baginya untuk menempatkansekaliobservasi tadi (menimbang) dalam konteks dan mengidentifikasi kecenderungannya. Apakah berat badan anak ini terus bertambah? Apakah berat badannya stabil? Atau menurun? Kecenderungan yang ditemukannya akan bicara banyak tentang pertumbuhan si anak. Tanpa observasi yang sistematis, petugas ini mungkin menduga bahwa ada sesuatu yang salah tapi tidak tahu dengan pasti, atau tidak dapat mengasumsikan segala sesuatunya baik-baik saja meskipun sebenarnya perubahan penting telah terjadi. Jika petugas ini juga menggunakan informasi yang diperolehnya dari observasi lain selama beberapa tahun, maka

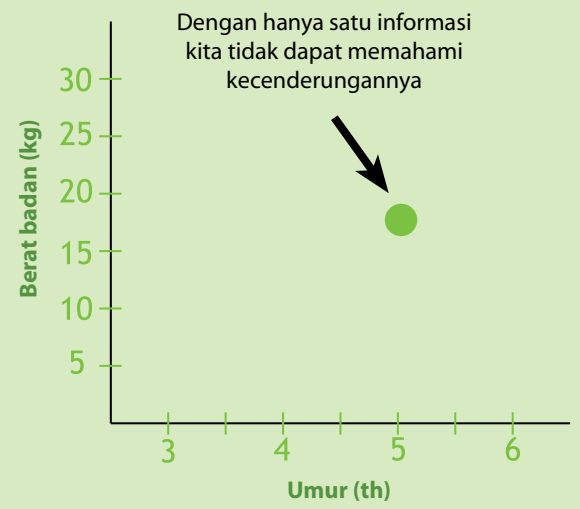

akan mungkin baginya untuk menempatkan kecenderungan tadi dalam konteks yang lebih luas, dan mengajukan pertanyaan penting: Apakah perubahan ini tak terduga, atau abnormal?

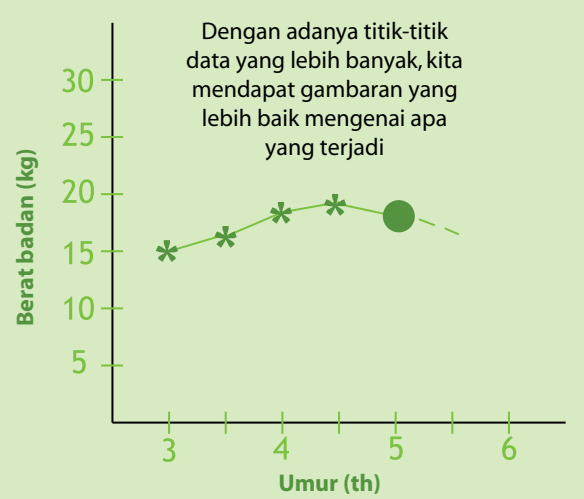


dihadapi oleh masyarakat setempat. Dengan memantau dampak dari program-program dan layanan-layanannya, pemerintah daerah dapat memahami apakah program-program tersebut berguna bagi masyarakat dan mengidentifikasi peluang untuk meningkatkannya. Informasi ini sangat berguna dalam menetapkan prioritas dan merencanakan aktivitas. Misalnya, pemantauan dapat membantu pemerintah daerah menjawab pertanyaan-pertanyaan seperti:

- Dibanding sebelumnya, apakah ketersediaan listrik per hari dan per rumah lebih baik?

- Apakah transportasi untuk masyarakat meningkat? Apakah rata-rata waktu tempuh ke lokasi masyarakat berkurang?

- Apakah kejadian malaria di daerah meningkat atau berkurang? Apakah program pemberantasan malaria menampakkan hasil?

Saat ini, pemantauan memang sudah dilakukan tetapi sering dilakukan tanpa pemikiran yang matang atau sekedar dilakukan untuk memenuhi persyaratan pelaporan. Sebagai akibatnya, kaitan antara pemantauan dan proses pengambilan keputusan biasanya lemah. Pemerintah daerah sering mengalami keterbatasan waktu dan sumber daya, dan sering tidak memprioritaskan pemantauan. Kadang-kadang mereka salah menganggap bahwa pemantauan sama dengan pengauditan dan menghadapi dengan perasaan was-was.

Pemantauan penting bagi pemerintah daerah karena sejumlah alasan.

1. Pemantauan membantu pemerintah daerah menelusuri apa saja yang sedang ia kerjakan. Pemerintah daerah dapat menilai proses-proses yang penting bagi jalannya pemerintahannya, seperti kapan pertemuan harus diadakan, siapa yang menghadirinya, dan bagaimana proyek pemerintah telah diimplementasikan. Ini disebut pemantauan proses.
2. Dengan pemantauan, perubahan kondisi dari waktu ke waktu dapat diketahui. Apakah keadaan bertambah baik, bertambah buruk atau tidak berubah? Jenis pemantauan ini berusaha menguraikan keadaan berdasarkan pengukuran berulang atas indikatorindikator yang dipilih untuk mengamati perubahan. Apakah kesejahteraan rumah tangga meningkat? Apakah mutu air minum semakin memburuk? Dengan terus menerus memantau parameter-parameter ini, pemerintah daerah dapat memahami karakteristik kemiskinan dan kesejahteraan secara lebih baik.

3. Jika hasil-hasil di atas dibandingkan, maka hubungan antara tindakan dan dampaknya akan dapat diketahui. Dengan mengumpulkan informasi tentang implementasi program secara sistematis, juga informasi tentang perubahan di bidang-bidang yang terkena dampak implementasi program tersebut, pemerintah daerah dapat mengidentifikasi apakah program yang dijalankannya memberi pengaruh dan apakah pengaruhnya sepadan dengan usaha yang ditanamkan. Misalnya, pemerintah daerah yang telah mendanai program percobaan sarapan pagi di sekolah ingin memperluas program tersebut dan berusaha mencari pendanaan dari mitra pendamping. Tetapi, pemerintah daerah hanya bisa mengatakan bahwa program itu berhasil jika ia dapat menunjukkan bahwa program sarapan pagi di sekolah tersebut dijalankan, mencapai sasaran yang dimaksud dan anak-anak yang jadi sasaran mendapatkan gizi yang lebih baik. Kaitan antara tindakan dan hasil ini mengindikasikan apakah program yang dijalankan berhasil atau gagal. Ini disebut pemantauan dampak. 
4. Pemantauan membantu pemerintah membuat perencanaan yang lebih baik. Pemantauan menghasilkan informasi untuk menjawab pertanyaan yang dapat membantu pemerintah daerah memprioritaskan dan membidik aktivitas (di mana, siapa, apa masalahnya, dll.).

5. Informasi yang diperoleh dari pemantauan juga membantu pemerintah daerah mendokumentasikan dan mendemonstrasikan tindakan atau kebutuhannya. Menyediakan informasi bagi konstituen merupakan langkah penting untuk justifikasi program, selain juga memberi konstituen kesempatan untuk mengevaluasi kemajuan. Informasi ini mungkin diperlukan untuk mendapatkan mitra pendanaan untuk investasi pembangunan di masa mendatang.

\section{Jenis-jenis pemantauan}

Pemantauan dan evaluasi dapat dimasukkan dalam setiap langkah siklus proyek. Ada dua jenis pemantauan yang lazim: pemantauan proses dan pemantauan dampak.

Pemantauan proses berfokus pada implementasi tindakan pemerintah daerah. Pemantauan proses dapat membantu menjawab pertanyaan seperti: Apakah partisipasi masyarakat dalam pertemuan anggaran tahunan meningkat? Apakah informasi resmi sudah disebarkan ke semua masyarakat? Pemantauan proses ini penting karena dengannya pemerintah daerah dan masyarakat dapat menelusuri bagaimana program-program dijalankan dan mengidentifikasi cara untuk meningkatkannya.

Pemantauan dampak berfokus pada perubahan yang terjadi sebagai akibat dari tindakan pemerintah daerah. Di sinilah keberhasilan dan kegagalan biasanya diukur berdasarkan tujuan dan sasaran awal. Misalnya, apakah kemampuan baca tulis meningkat sebagai akibat dari layanan pendidikan yang lebih baik? Apakah jumlah kasus malaria berkurang sebagai akibat dari membaiknya layanan kesehatan? Tetapi pemantauan dampak memiliki kelemahan, yakni hubungan sebab-akibat yang kuat tidak selalu memungkinkan untuk dibentuk. Turunnya angka kematian akibat malaria bisa jadi merupakan akibat dari perubahan lingkungan. Tetapi jika angka kematian tidak berubah meski program kesehatan telah dijalankan, barulah berarti bahwa tindakan untuk melawan penyakit ini belum membuahkan hasil.

\section{Indikator}

Indikator memberikan informasi yang relevan dan terukur tentang suatu situasi atau kecenderungan. Ini adalah petunjuk ke arah kenyataan yang lebih kompleks. Indikator dapat dinyatakan dengan angka, misalnya, kilometer jalan yang telah dikeraskan di kabupaten atau persentase anggota masyarakat yang menghadiri pertemuan. Indikator dapat juga menyatakan kualitas sesuatu berdasarkan opini atau persepsi, misalnya, apakah orang merasa transportasi semakin sulit atau semakin mudah, atau apakah sekolah memberi pendidikan yang lebih baik.

Pada contoh berat badan anak di atas (Kotak 6), pertanyaan pemantauannya adalah 'Apakah anak ini sehat?' Untuk menjawab pertanyaan itu, kita memilih indikator, yaitu berat badan anak. Berat badan tidak sama dengan kesehatan, tetapi dengan mengetahui bahwa berat badan anak tersebut normal, atau bertambah dengan normal, kita bisa tahu sedikit tentang kesehatannya. Misalnya, anak yang berat badannya turun mungkin sakit, dan dalam hal ini turunnya berat badan adalah efek samping dari sakit. Anak tersebut mungkin mengalami penurunan berat badan karena kurang gizi; dan dalam hal ini penurunan berat badan mengindikasikan kurangnya makanan sekaligus adanya masalah kesehatan. 
Kita bisa pula menggunakan indikator yang berupa ungkapan suatu pendapat, misalnya, meminta pakar kesehatan untuk membuat penilaian tentang kesehatan anak tadi. Langkah ini akan menghasilkan lebih banyak informasi untuk melengkapi indikator berat badan.

\section{Kapan melakukan pemantauan?}

Contoh pada Kotak 6 menunjukkan bahwa data yang dikumpulkan dengan sekali pengamatan tidak dapat menghasilkan kesimpulan yang bermakna tentang ada tidaknya perubahan. Informasi harus dikumpulkan secara konsisten dan pada interval-interval yang masuk akal untuk suatu permasalahan tertentu. Apakah informasi itu harus dikumpulkan setiap minggu? Setiap bulan? Setiap tahun? Frekuensinya bergantung pada tujuan pemantauan. Jika berat badan anak dipantau untuk mengidentifikasi masalah kesehatan, maka tidak cukup dilakukan pemantauan setiap tahun. Di sisi lain, jika berat badan anak dipantau setiap minggu, maka hal itu akan terlalu memberatkan. Kuncinya adalah keseimbangan dengan melakukan observasi yang cukup untuk mengidentifikasi dan menindaklanjuti kecenderungan-kecenderungan penting tanpa harus menjadikan proses itu terlampau mahal atau memakan waktu.

Data harus dikumpulkan pada waktu-waktu penting. Misalnya, sensus di Bolivia dilakukan selama musim kering di Pando, saat kebanyakan keluarga tinggal di kotamadyakotamadya perkotaan. Otoritas kesehatan daerah menggunakan informasi penduduk yang diperoleh dari sensus ini untuk menentukan bagaimana sumber daya kesehatan harus disebar ke kotamadya-kotamadya. Tetapi, selama musim penghujan, kotamadya-kotamadya dengan daerah berhutan menjadi amat terbebani oleh keluarga-keluarga yang datang untuk memanen kacang Brasil. Pos-pos kesehatan harus berjuang keras untuk menyediakan layanan kepada lonjakan warga ini, karena sumber daya mereka telah dikondisikan untuk jumlah penduduk yang lebih kecil selama musim kering. Selain itu, musim penghujan adalah waktu puncak untuk malaria, dan hal ini kian memperberat layanan kesehatan. Dalam situasi semacam ini, data sensus yang tidak akurat menyimpangkan sebaran sumber daya kesehatan. Idealnya, data demografi harus mempertimbangkan migrasi musiman agar gambaran yang diperoleh lebih akurat.

\section{Siapa yang melakukan pemantauan?}

Ada banyak peran dalam pemantauan, mulai dari merancang dan menerapkan rencana pemantauan sampai menganalisa dan menyebarkan hasil pemantauan. Siapa yang akan mengisi peran-peran ini tergantung pada tujuan program pemantauan, aksesibilitas data, lokasi data dan anggaran. Pemantauan tidak harus menjadi aktivitas eksklusif bagi pemerintah daerah. Dalam kenyataannya, konstituen dan kelompok-kelompok kepentingan harus didorong untuk ikut berpartisipasi dalam pemantauan. Jika warga memiliki pengaruh dan keterlibatan dalam pemantauan, maka mereka akan menunjukkan rasa kepemilikan dan minat yang lebih terhadap hasilnya. Dengan melibatkan lebih banyak orang dalam proses pemantauan, pemerintah daerah meningkatkan kredibilitasnya melalui transparansi yang lebih baik. 


\section{Menghubungkan pemantauan dengan perencanaan}

Pemantauan penting bagi pemerintah daerah karena pemantauan meningkatkan proses perencanaan. Jika dilakukan dengan benar, pemantauan kemiskinan akan menghasilkan informasi yang andal tentang kecenderungan kemiskinan di suatu kabupaten atau kotamadya. Dengan informasi ini, para pengambil keputusan akan dapat menjawab pertanyaanpertanyaan seperti:

- Siapa yang miskin?

- Seberapa miskinkah mereka?

- Di mana mereka tinggal?

- Mengapa mereka miskin?

- Apa yang dapat dilakukan

- Bagaimana fakta-fakta ini berubah dari waktu ke waktu?

Dengan berbekal informasi ini, pemerintah daerah dapat mengidentifikasi prioritas strategis dalam berjuang melawan kemiskinan. Selanjutnya prioritas ini dapat dikomunikasikan ke jenjang pemerintah yang lain dan ke masyarakat. Pimpinan masyarakat akan mengetahui apa yang menjadi prioritas dan berapa anggaran yang tersedia sebelum memulai proses perencanaannya sendiri. Perencanaan mereka akan menjadi lebih realistis dan terfokus.

Alat-alat yang dijelaskan pada bagian-bagian di bawah ini merupakan contoh bahwa pemantauan dapat menghasilkan informasi penting saat merencanakan program untuk menanggulangi kemiskinan. 


\section{Perencanaan}

partisipatif

\section{Apakah perencanaan partisipatif itu?}

Perencanaan adalah proses sistematis untuk menyiapkan diri menyambut masa depan dengan menetapkan tujuan, memilih strategi, memilih aktivitas, membuat jadwal atau menganggarkan sumberdaya untuk suatu periode waktu tertentu. Jika orang yang berbeda dengan kebutuhan, persepsi, kewenangan dan tanggung jawab yang berbeda dilibatkan dalam perencanaan, maka itu disebut perencanaan partisipatif. Secara umum perencanaan partisipatif terdiri dari langkahlangkah berikut (urutannya tidak harus sama): pemerintah daerah menyajikan proposal, mengumpulkan umpan balik dan masukan dari konstituen, dan berusaha membangun kesepahaman antar kelompok kepentingan yang berbeda. Perencanaan pemanfaatan lahan dan anggaran pemerintah tahunan adalah contoh rencana yang dapat melibatkan tinjauan atau masukan dari warga sebelum rencana itu disahkan.

\section{Mengapa perencanaan partisipatif perlu?}

Perencanaan partisipatif penting karena sejumlah alasan, termasuk di antaranya:
Kotak 7. Fakta di Boliva: Perencanaan partisipatif di Pando

Program pemantauan merupakan mekanisme yang baik untuk menggalang partisipasi warga dalam perencanaan dan pembuatan keputusan pemerintah daerah. Di Pando, kelompok warga berpartisipasi dalam proyek pemetaan interaktif untuk membuat peta kemiskinan. Dengan menggabungkan kemampuan, kelompok tersebut dapat mengembangkan representasi grafis dari faktor-faktor penting yang mempengaruhi kesejahteraan masyarakat, seperti serangan malaria, tantangan transportasi dan produktivitas kacang Brasil. Kegiatan ini berhasil bukan hanya karena dapat mengumpulkan informasi berharga dalam waktu cepat, tetapi juga karena dapat membangkitkan minat masyarakat untuk berpartisipasi dalam pembuatan keputusan pemerintah daerah. Keterlibatan masyarakat juga merupakan fungsi pengawasan dan meningkatkan akuntabilitas sistem pemantauan.

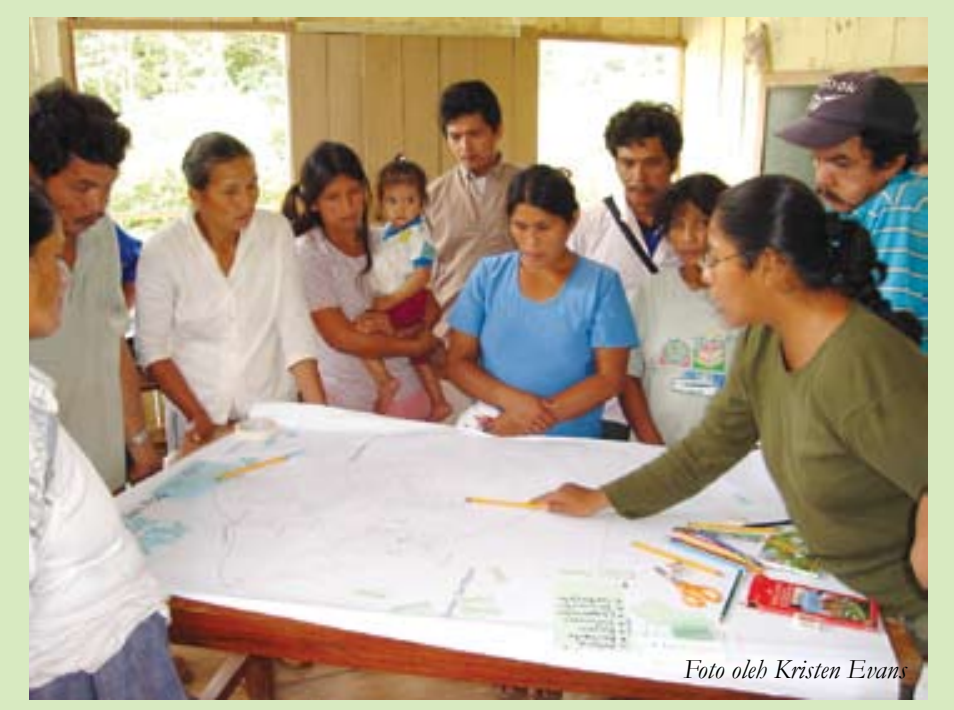


- Dapat meningkatkan mutu pemerintahan daerah dengan menciptakan proses yang lebih demokratis dan patut. Warga miskin sering memiliki sedikit suara, bahkan kadang tidak sama sekali, dalam keputusan pemerintah. Konsultasi dan dialog antara pemerintah daerah dan kelompok kepentingan yang mewakili warga miskin dapat memberi mereka suara dan pengaruh yang lebih besar terhadap keputusan pemerintah.

- Mendorong warga miskin untuk lebih bertanggung jawab atas, terlibat dalam, dan menyadari peran mereka dalam pemerintahan daerah. Langkah ini dapat mengurangi potensi konflik dan membangun rasa kepemilikan warga atas rencana yang dibuat pemerintah.

- Dapat menghasilkan program yang lebih baik dan lebih efisien. Dengan berkonsultasi dengan warga miskin dan memberi mereka kesempatan menyuarakan kebutuhan dan pemikirannya, tindakan yang dihasilkan akan lebih relevan dan sesuai dengan kondisi yang mereka hadapi. Misalnya, dengan menanyai warga tentang jadwal harian mereka, pemerintah daerah dapat menyediakan layanan pada waktu-waktu dimana masyarakat paling mungkin memanfaatkannya sebaik-baiknya.

- Dapat meningkatkan transparansi dalam pengambilan keputusan pemerintah. Langkah ini memungkinkan warga untuk memahami bagaimana dan mengapa pemerintah daerah mengambil keputusan tertentu. Selain itu langkah ini dapat membuat anggota pemerintahan bertanggung jawab atas apa yang mereka rencanakan. Saling pengertian dan saling percaya antara warga miskin dan pemerintah daerah dapat meningkat karenanya.

Meski memiliki banyak keuntungan, perencanaan partisipatif kadang menguras tenaga dan waktu. Merencanakan program pemerintah itu kompleks dan sulit, dan prosesnya akan lebih berat lagi saat banyak pelaku dilibatkan. Perencanaan partisipatif sering membutuhkan pertemuan-pertemuan tambahan untuk menjelaskan proses, memperdebatkan proposal dan mencapai keputusan. Hal ini dapat problematis pada bidang-bidang dimana mandat yang dipegang pemerintah daerah kurang dipahami, atau jika ada pengharapan yang tidak realistis tentang apa yang dapat atau harus dilakukan pemerintah.

Seringkali fasilitasi, atau bahkan mediasi, diperlukan untuk mencapai keputusan tentang program-program dan 'imbangannya' atau untung-ruginya. Sebagian kelompok atau perorangan mungkin lebih memilih untuk memperlambat proses daripada mencapai keputusan yang tidak memihak pada kepentingannya. Proses ini juga dapat dimanipulasi oleh pemerintah untuk membujuk konstituen agar menerima rencana yang sudah ditetapkan sebelumnya.

\section{Kapan dan di mana perencanaan partisipatif dilakukan?}

Perencanaan partisipatif biasanya melibatkan konsultasi publik dan pertemuan-pertemuan di luar ibu kota. Seringkali pertemuan ini harus diadakan di lokasi yang lebih terjangkau oleh warga miskin, seperti di masyarakat pedesaan. Perencanaan partisipatif dapat melibatkan kegiatan lain, seperti melakukan kunjungan lapangan ke hutan atau masyarakat terpencil, atau mengadakan jajak pendapat untuk mengetahui pandangan warga.

Kapan kegiatan ini dilakukan bergantung pada kerangka waktu dalam siklus perencanaan. Pemerintah biasanya menjalankan siklus perencanaan tahunan, yang melibatkan penjadwalan kegiatan selama tahun tersebut untuk memastikan bahwa semua rencana diserahkan pada waktu yang ditentukan. Perencanaan multitahun (misalnya, 3 tahun, 5 tahun, 10 tahun) 
Kotak 8. Fakta di Indonesia: Jebakan perencanaan

Di Indonesia, masyarakat berhak mengusulkan proyek pembangunan ke pemerintah daerah. Usulanusulan ini dikumpulkan di tingkat kecamatan dan kemudian diserahkan ke kabupaten, tetapi seringkali dengan perubahan yang substansial. Biasanya, masyarakat tidak pernah mengetahui kelanjutan proposal mereka, dan banyak proyek dilaksanakan tanpa adanya konsultasi terlebih dahulu dengan masyarakat. Kurangnya komunikasi dan partisipasi ini menyebabkan masyarakat terbiasa menyerahkan daftar permintaan panjang tanpa prioritas, karena mereka takut dianggap terlalu sederhana. Akibatnya, badan-badan teknis kabupaten tidak menghiraukan masyarakat dan melaksanakan rencana mereka sendiri, yang seringkali tidak merespons permintaan masyarakat setempat.

kurang sering dipakai. Perencanaan partisipatif dapat juga digunakan untuk proyek-proyek spesifik dalam jangka waktu yang pendek.

Saat menjadwalkan aktivitas, pejabat pemerintah harus mempertimbangkan aktivitas lain seperti peringatan keagamaan atau pekerjaan pertanian. Benturan jadwal dapat membatasi kemampuan sebagian kelompok atau perorangan untuk berpartisipasi.

\section{Siapa yang harus berpartisipasi?}

Tidak jarang siapa saja yang boleh terlibat dalam proses perencanaan partisipatif ditentukan berdasarkan undangundang. Di Bolivia, misalnya, pemerintah kotamadya diharuskan berkonsultasi semua masyarakat yang terdaftar secara legal di dalam wilayah administrasi. Kotamadya mendapatkan fleksibilitas untuk menentukan bagaimana konsultasi tersebut dilakukan dan jenis partisipasi seperti apa yang boleh diberikan.

Pemerintah daerah yang peduli untuk menanggapi kebutuhan masyarakat miskin harus mengambil langkah-langkah untuk memastikan bahwa pandangan dari berbagai kelompok kepentingan dalam kalangan warga miskin dicakup dalam konsultasi tersebut. Bahkan sekalipun pemerintah daerah tidak diharuskan untuk menanggapi kepentingan dari semua kelompok yang hadir, selalu ada baiknya untuk mengetahui pendapat dan persepsi lain yang berkembang untuk menghindari konflik dan memastikan dukungan.

Saat menentukan siapa yang harus berpartisipasi, pemerintah daerah harus memulainya dengan mengidentifikasi semua kelompok kepentingan yang mungkin ada dalam wilayah administrasinya. Kelompok-kelompok itu dapat ditentukan melalui berbagai cara, misalnya berdasarkan tingkat kesejahteraannya atau apakah mereka memiliki kepentingan tertentu dalam keputusan itu (misalnya, melibatkan orang tua dalam keputusan mengenai sekolah). Kelompok lain dapat ditentukan berdasarkan identitasnya, seperti lakilaki, perempuan, pemuda, manula, anggota kelompok atau kelompok etnis tertentu dan semacamnya. Dapat juga mereka ditentukan berdasarkan penghidupannya atau sebagai pengguna sumber daya hutan tertentu. Masyarakat dalam suatu kelompok kepentingan harus mendapatkan kesempatan untuk memastikan 
apakah mereka termasuk dalam kelompok yang satu, atau yang lainnya.

Untuk setiap usulan, cara penentuan kelompok dapat berlainan. Pendapat kelompok tertentu bisa diberi bobot lebih besar daripada pendapat dari kelompok lain karena mereka mungkin menanggung konsekuensi atau menangguk keuntungan dari dampak tertentu.

Strategi tertentu untuk memperkuat partisipasi setiap kelompok sebaiknya disesuaikan. Sebagian kelompok, terutama mereka yang sangat miskin, mungkin kesulitan untuk menghadiri pertemuan di tempat yang jauh. Dalam banyak kasus, perwakilan kelompok perlu diundang. Tetapi di sini perlu dipastikan bahwa perwakilan tersebut dipilih secara patut, bahwa mereka membawa suara dari anggota-anggota lain dalam kelompoknya, dan bahwa mereka akan melapor balik untuk menjaga akuntabilitas. Setelah dikembangkan strategi untuk memaksimalkan partisipasi, pemantauan untuk melihat apakah rencana itu menghasilkan tingkat partisipasi yang dikehendaki atau tidak dapat mengindikasikan apakah strategi tersebut perlu disesuaikan atau tidak. 
Alat 1:

Memantau konteks kemiskinan lokal melalui pemetaan interaktif

\section{Apakah pemetaan interaktif itu?}

Pemetaan interaktif adalah alat partisipatif untuk mengatur informasi kemiskinan dan pengetahuan lokal secara visual di atas peta. Setiap informasi dapat dimasukkan ke dalam peta, seperti serangan penyakit, kualitas jalan, tempat layanan kesehatan, atau pendapatan keluarga, tergantung pada isu-isu apa saja yang relevan untuk tempat tersebut. Bagan data seringkali sulit dipahami. Tetapi saat informasi yang sama disajikan di atas peta, maka informasi itu akan lebih berguna dan lebih mudah dipahami oleh lebih banyak warga.

Metode ini membentuk kemampuan warga setempat untuk membuat peta acuan sederhana yang dapat dimodifikasi untuk menyajikan jenis data yang beragam dan diperbarui saat tersedia informasi baru. Peta ini dapat dibuat dengan tangan atau, jika kecakapan dan peralatannya memungkinkan,

\section{Kotak 9. Mengapa dikatakan interaktif?}

Metode ini melibatkan proses revisi dan evaluasi peta lokal secara terus-menerus.

- Kelompok lokal dan pejabat pemerintah bertemu untuk berbagi informasi, baik tentang data yang ada atau pengetahuan berdasarkan eksperimen.

- Mereka mengubah informasi tersebut menjadi format peta.

- Mereka mengevaluasi peta itu secara terbuka. Ini dilakukan untuk memvalidasi peta. Juga untuk meningkatkan kredibilitas dan kualitas peta.

- Peta ini terus diperbarui berdasarkan informasi baru dan dievaluasi. 


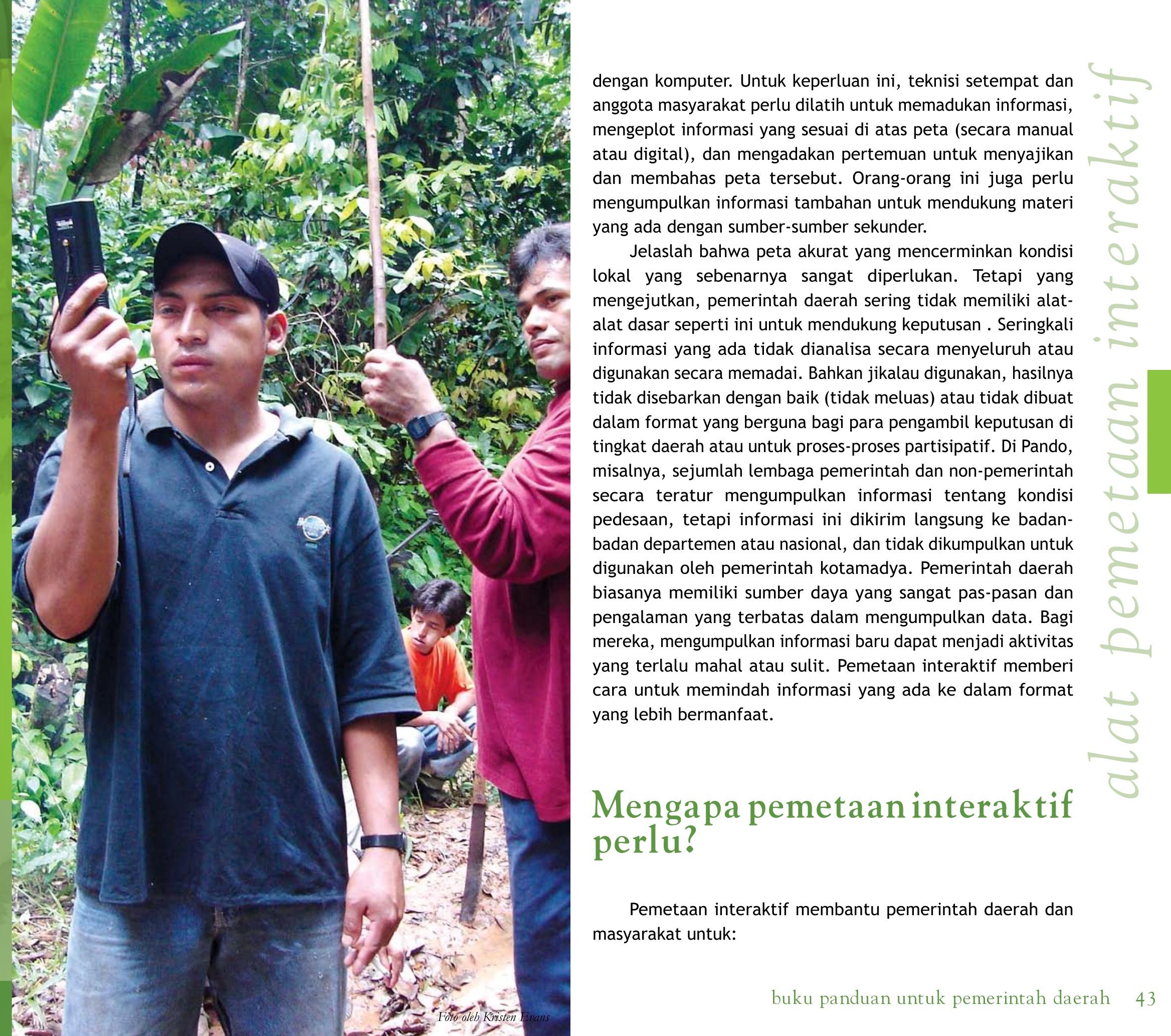


- mengelola informasi yang ada dan meningkatkan koordinasi antarbadan

- menelusuri perubahan kemiskinan dalam wilayah administrasinya guna menyesuaikan perencanaan dengan memprioritaskan dan memfokuskan intervensi

- meningkatkan transparansi dan dialog antara pemerintah daerah dan konstituennya.

Pemetaan intraktif menunjukkan dimana warga tinggal, jenis sumber daya yang mereka miliki, tantangan yang mereka hadapi, dan apakah program dan layanan pemerintah bisa menjangkau mereka.

Dengan penyajian semacam ini, informasi lokal akan lebih mudah diakses oleh warga yang kemungkinan kecil akan membaca laporan dan tabel-tabel, serta memberi cara untuk menyajikan dan membahas informasi secara terbuka. Jika dilakukan pada interval teratur, pemetaan partisipatif akan berguna untuk menelusuri perubahan.

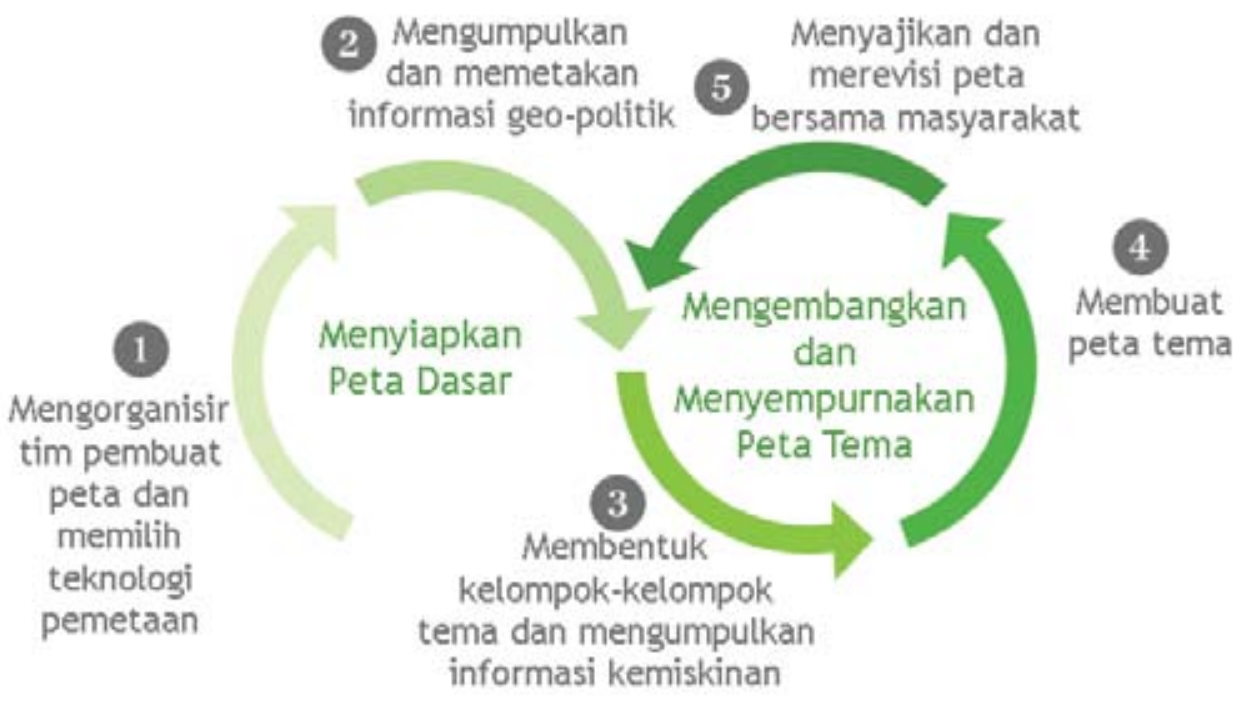

\section{Cara melakukan pemetaan interaktif: Langkah demi langkah}

Alat ini terdiri dari lima langkah dasar (lihat Gambar 5). Pertama, mengidentifikasi dan melatih tim inti pembuat peta dan memilih teknologi pemetaan yang tepat. Kedua, menyiapkan peta dasar geo-politik, misalnya yang dilengkapi dengan lokasi pemukiman warga, jalan, dan sungai. Ketiga, menyusun tim yang terdiri dari para ahli setempat untuk meninjau dan mengatur informasi yang akan ditambahkan untuk menciptakan peta tema. Keempat, memasukkan informasi ke dalam peta. Kelima, menyajikan peta dasar dan peta tema secara umum untuk mendapatkan komentar dan evaluasi.

Langkah 3, 4 dan 5 harus diulangulang saat tersedia informasi yang lebih banyak untuk membuat peta yang lebih akurat. Idealnya, proses ini dilakukan setiap tahun agar sesuai dengan siklus anggaran dan perencanaan pemerintah daerah.

\section{Langkah 1. Mengorganisir tim pembuat peta lokal dan memilih teknologi pemetaan}

Pilihlah sekelompok kecil (6-8) orang sukarelawan yang berminat untuk belajar tentang teknologi dan teknik pemetaan yang baru. Peserta pelatihan ini sebaiknya berasal dari pemerintah daerah, lembaga lokal 


\section{Kotak 10. Waktu dan peralatan untuk} membuat peta dasar

Waktu dan peralatan variabel tergantung pada informasi yang tersedia dan tingkat kemampuan masyarakat setempat.

- Waktu untuk mengumpulkan informasi kartografi (5 jam) (dengan asumsi belum ada peta dasar)

- Pelatihan GPS (1 hari): penggunaan GPS dan metode kartografi dasar

- Lokakarya tentang peta (1 hari)

- Komputer, GPS, buku catatan, kertas kisi-kisi, diagram flip.

\section{Tim dan para peserta}

- 1 fasilitator

- 1 pencatat

- 3 sampai 10 peserta (teknisi pemerintah atau ahli lainnya), mereka akan membuat peta

dan masyarakat. Peserta harus menguasai baca tulis dan bisa menghitung. Dengan melatih warga setempat untuk menjadi pembuat peta, proses pembuatan peta akan bersifat partisipatif sekaligus lebih efisien.

Pilihlah teknologi pemetaan yang sesuai. Ada banyak cara untuk membuat peta. Tingkat teknologi yang tersedia juga bermacam-macam, tergantung pada alat yang digunakan. Penggunaan GPS (Global Positioning System) genggam untuk lokasi geo-referensi sangat dianjurkan karena GPS mudah digunakan dan data koordinat dapat diterapkan dalam proses pemetaan dengan atau tanpa komputer. Koordinat geo-referensi menjadi dasar dari informasi yang kemudian dimasukkan ke dalam peta. GPS akan sangat pas dipasangkan dengan perangkat lunak pemetaan, seperti ArcView, jika komputer tersedia. Tetapi jika akses ke komputer tidak mungkin dilakukan, maka akan lebih efektif bila kisi-kisi koordinat digambar di atas selembar kertas lebar (atau beberapa lembar kertas yang lebih kecil yang disambung) dan koordinat GPS ditandai pada kisi-kisi tersebut. Harap diingat bahwa peta harus dapat disalin.

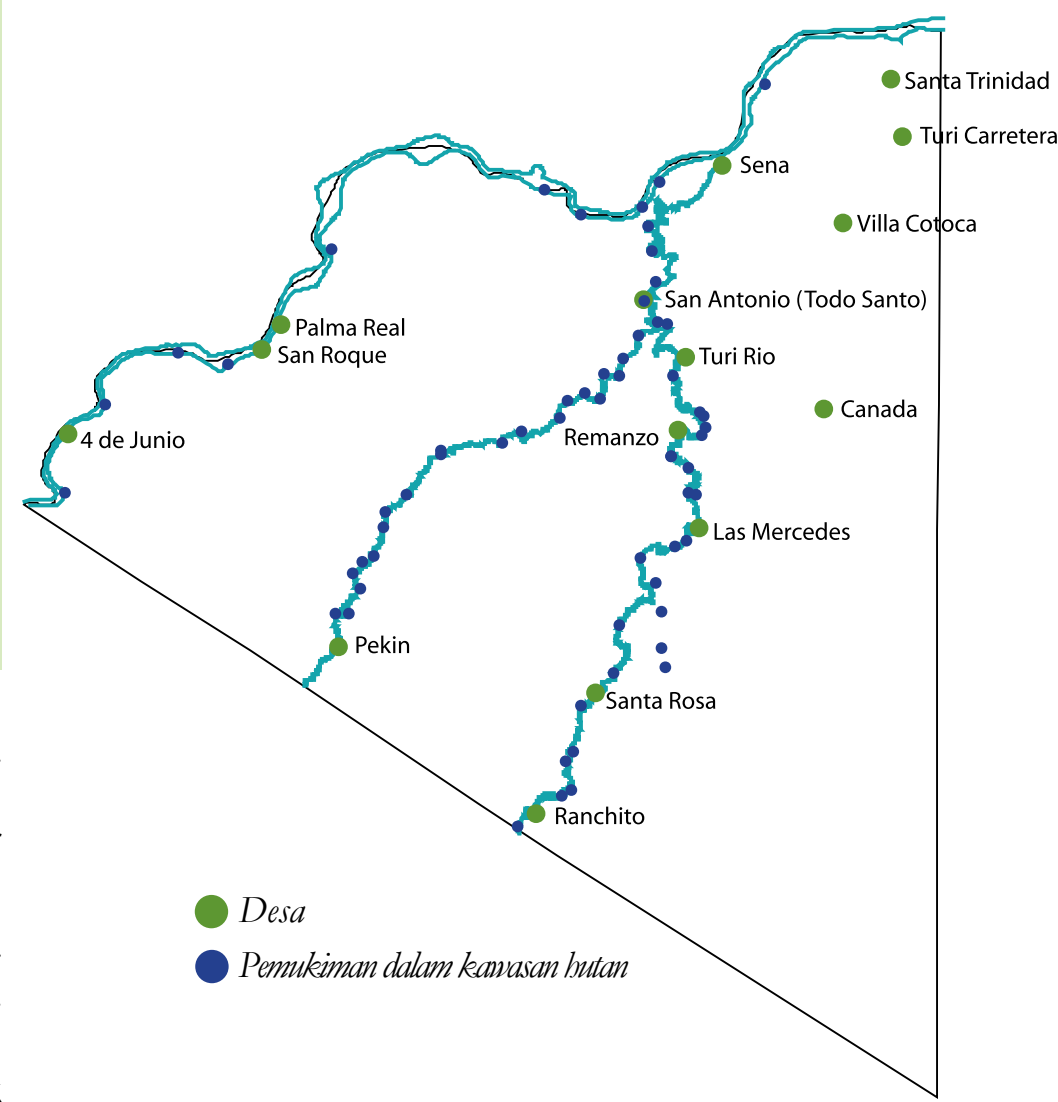

Gambar 6. Peta dasar kotamadya El Sena, Bolivia dengan sungai, jalan, pemukiman masyarakat, properti pribadi dan kawasan hutan. 
Aturlah beberapa kegiatan di dalam masyarakat dan hutan di sekitarnya. Rantai pelatihan merupakan metode yang efektif, dimana orang pertama belajar cara membuat titik GPS dan kemudian dia melatih orang berikutnya. Metode ini mengajari warga cara melatih warga lain.

\section{Langkah 2. Menyiapkan peta dasar}

Peta dasar adalah peta geo-politik yang menunjukkan batas-batas, pemukiman masyarakat, sungai, danau, jalan dan jembatan. Peta dasar berfungsi sebagai titik awal untuk membuat peta tema yang menampilkan informasi tentang kemiskinan, kesejahteraan, proyek, hubungan atau kondisi lokal lainnya.

Pemerintah daerah mungkin sudah memiliki peta dasar yang baik. Jika belum, tanyakan ke berbagai badan dan organisasi pemerintah (lihat Kotak 11). Carilah sumber informasi tambahan, seperti database informasi geo-referensi dan citra satelit.

Gabungkan informasi ini ke dalam satu peta. Pastikan bahwa rincian yang ada memadai. Jika lokasi yang memiliki makna yang penting tidak tampak, lakukan kunjungan lapangan dengan GPS untuk mengumpulkan data tersebut.

Bagikan peta dasar itu kepada konstituen setempat (misalnya, anggota masyarakat, pemilik lahan, pedagang dan pejabat setempat) untuk ditinjau sebelum melanjutkan ke langkah berikutnya. Koreksi kesalahan atau informasi yang tidak ada. Perbanyak peta dasar ini untuk langkah selanjutnya.

Langkah 3. Membentuk kelompok-kelompok tema dan mengumpulkan informasi kemiskinan

Identifikasi peta tema yang akan berguna untuk mengambil keputusan dan merencanakan penanggulangan kemiskinan.

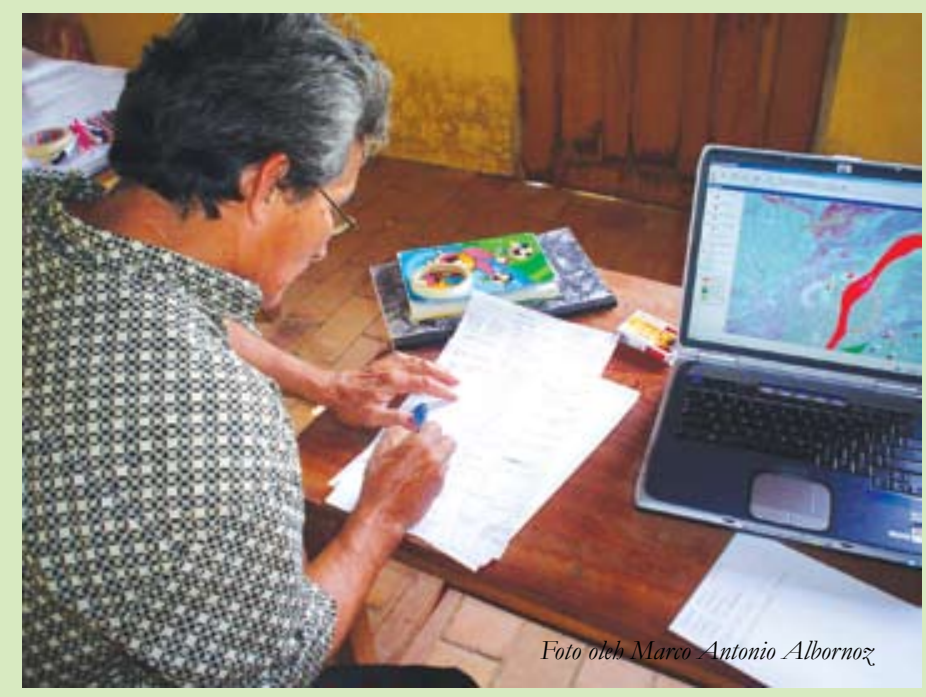

Kotak 11. Mengembangkan peta dasar di Bolivia

Di Bolivia, tidak ada peta kotamadya yang akurat. Namun, informasi kartografi yang diperlukan dapat disusun dari sumber-sumber yang berbeda sampai menghasilkan satu peta dasar. Informasinya diperoleh dari berbagai organisasi:

- Military Geography Institute

- National Land Reform Institute

- National Forestry Superintendency

- Municipal Border Commission.

Karena peserta di Bolivia memiliki keterampilan komputer yang baik, tim menggabungkan informasi dengan analisis mereka sendiri untuk menghasilkan peta dasar versi elektronik. 
Misalnya, peta kasus malaria akan berguna untuk kampanye pemberantasan penyakit (lihat Gambar 7).

Untuk setiap peta tema, bentuklah kelompok fokus yang terdiri dari para ahli setempat yang menguasai topik tersebut dan dapat menyumbangkan informasi atau pengetahuan lokal mereka mendalam mengenai permasalahan itu. Berikut beberapa contoh tema dan komposisi kelompok yang mungkin:

- Sektor ekonomi. Peserta dapat meliputi pedagang setempat, pemilik lahan hutan dan petani. Mereka dapat menggunakan statistik produksi resmi atau informasi produsen dari asosiasi atau federasi setempat. Kelompok fokus ini juga dapat memanfaatkan keahlian perorangan untuk mengidentifikasi pusat-pusat pengumpulan atau produksi utama atau lokasi-lokasi yang memiliki sumber daya alam penting.

- Kesehatan masyarakat. Peserta dapat meliputi petugas kesehatan setempat, pejabat pemerintah yang mengetahui anggaran untuk masyarakat, dan bahkan pekerja seperti operator perahu yang sering mengantarkan warga sakit di tempat-tempat yang tidak memiliki layanan transportasi yang reguler. Kelompok ini dapat meninjau statistik resmi untuk mengidentifikasi informasi yang paling relevan dengan masalah setempat, misalnya, kejadian penyakit seperti malaria dan demam berdarah.

- Pekerjaan dan layanan publik. Peserta dapat meliputi spesialis pemerintahan setempat, tenaga kesehatan dan pendidikan, kontraktor dan perwakilan masyarakat. Kelompok ini dapat mengatalogkan lokasi dan kualitas infrastruktur, layanan dan program-program publik. Mereka dapat mengumpulkan informasi dari arsip masyarakat selain juga dari pengalaman pribadi di bidang-bidang yang terkait.

Setiap kelompok mempelajari informasi yang ada yang dikumpulkan dari lembaga-lembaga daerah (seperti layanan
Kotak 12. Waktu dan peralatan yang dibutuhkan untuk membuat peta tema

- Membentuk kelompok fokus - 1 hari Mengidentifikasi peserta, menggalang partisipasi dan menjelaskan tugas.

- Penelitian - Beragam untuk masing-masing peserta Menata informasi sekunder untuk digunakan dalam proses pemetaan.

- Pertemuan - 1 sampai 2 hari

Menyajikan dan membahas data sekunder, menyusun dan membuat sketsa peta dasar, mempelajari rancangan peta tema, penyelesaian.

- Peralatan

Peralatan pemetaan dasar seperti GPS, kertas kisikisi dan kompas. Program pemetaan komputer yang lebih canggih dapat digunakan bila para pesertanya sudah terampil.

\section{Tim dan peserta}

- 1 fasilitator

- 1 pencatat

- Teknisi peta dari pemerintah daerah

- 3 sampai 10 peserta per kelompok fokus.

pendidikan dan kesehatan, dan biro statistik nasional). Mereka juga dapat menyumbangkan pengetahuan dan pengalamannya masing-masing.

\section{Langkah 4. Membuat peta tema}

Berikan salinan peta dasar kepada setiap kelompok. Mintalah kelompok-kelompok itu untuk memikirkan cara-cara 


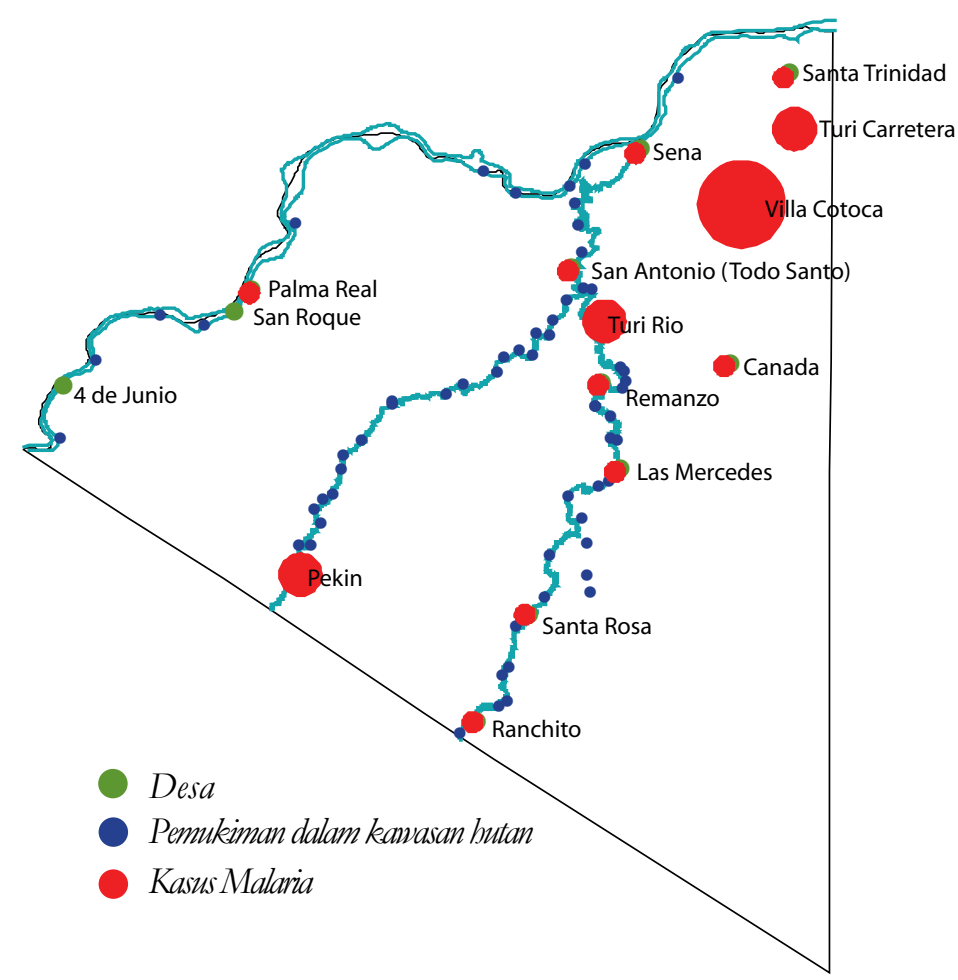

Gambar 7. Kasus malaria di beberapa pemukiman masyarakat di El Sena, Bolivia. Ukuran lingkaran menunjukkan jumlah kasus per pemukiman masyarakat per tahun.

menyajikan informasi tersebut di atas peta. Misalnya, Gambar 7 menunjukkan kasus malaria di sebuah kotamadya di Pando. Lingkaran merah menunjukkan tempat mewabahnya malaria, dan ukuran lingkaran merah tersebut menandakan berapa banyak kasus yang terjadi di setiap pemukiman masyarakat. Gambar 8 adalah contoh lain visualisasi informasi - garis-garis itu menunjukkan berapa waktu yang diperlukan untuk sampai ke ibu kota kotamadya.

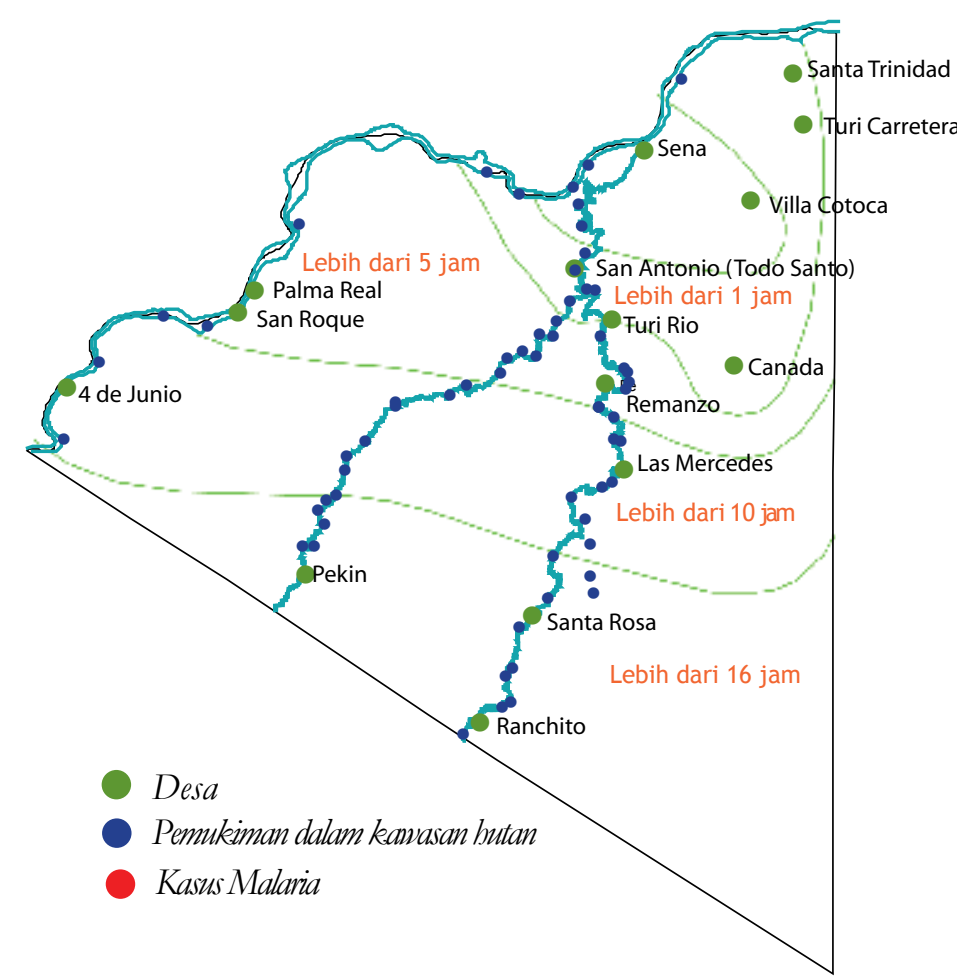

Gambar 8. Waktu tempuh (dalam jam) dari ibu kota kotamadya El Sena, Bolivia ke beberapa komunitas.

Mintalah kelompok-kelompok tadi untuk menggambarkan informasi tema itu di atas peta dasar. Mereka harus mendokumentasikan informasi dan mencatat bagaimana peta itu dikembangkan. Setelah semua kelompok sepakat bahwa informasi yang ada telah dilukiskan secara akurat, mereka harus menyiapkan versi terakhir (baik digital maupun plot dengan tangan, tergantung teknologi yang digunakan). 


\section{Kotak 13. Waktu dan peralatan}

- Penyiapan - 2 jam Mengulas presentasi bersama perwakilan kelompok fokus.

- Pertemuan publik - 4 jam (tergantung jumlah peta tema).

- Peralatan

Seperangkat peta lengkap (dasar dan tema), diagram flip, spidol, lembar ulasan.

\section{Tim dan peserta}

- 1 fasilitator

- 1 wakil dari masing-masing kelompok fokus tema

- Anggota masyarakat (5-12 per kelompok fokus).

Langkah 5. Menyajikan dan merevisi peta bersama masyarakat

Setelah peta dasar dan peta tema selesai, sajikan petapeta itu kepada publik untuk mendapatkan komentar dan evaluasi. Mintalah perwakilan dari setiap kelompok fokus menguraikan apa saja yang disajikan di dalam peta tema dan menjelaskan kesimpulan pokok yang dapat mereka tarik dari proses pembuatan peta. Mintalah publik mempertimbangkan apakah peta tersebut akurat dan membantu.

Kegiatan ini mempunyai beberapa tujuan:

- memvalidasi informasi yang dimasukkan ke dalam peta

- menyebarkan informasi tentang kondisi, program dan layanan lokal

- mengidentifikasi apakah diperlukan tema-tema lain atau dibutuhkan informasi yang lebih akurat.

\section{Kotak 14. Tip-tip untuk memulai}

Pemetaan interaktif menarik dan menyenangkan, sehingga mudah melibatkan warga setempat dalam kegiatan ini dari tahap paling awal.

- Selenggarakan pertemuan informal dengan pemerintah atau lembaga daerah untuk menyajikan konsepnya. Sampaikan contoh-contoh dalam buku ini. Bahas pentingnya pemantauan dan bagaimana pemetaan interaktif dapat berfungsi.

- Selenggarakan lokakarya pelatihan pemetaan. Ajarkan kecakapan-kecakapan pemetaan dasar dan cara menggunakan GPS. Undang pejabat pemerintah daerah dan anggota masyarakat setempat. Sertakan juga para pemuda yang sering gemar belajar teknologi baru.

- Dari kelompok ini, mintalah sukarelawan untuk menjadi anggota tim pemetaan. Pilihlah orang yang paling tertarik dan paling dapat diandalkan.

\section{Sumber Bacaan Lebih Lanjut:}

Eghenter, C. 2000 Mapping people's forests: the role of mapping in planning community-based management of conservation areas in Indonesia. Biodiversity Support Program, Washington, DC.

Jackson, B., Nurse, M.C. and Singh, H.B. 1994 Participatory mapping for community forestry. London: ODI.

Open Forum on Participatory Geographic Information Systems and Technologies. Website: http://ppgis.iapad.org.

Peluso, N.L. 1995 Whose woods are these? Counter-mapping forest territories in Kalimantan, Indonesia. Antipode 29(4): $383-406$. 
Harap selalu diingat bahwa tujuan aktivitas ini bukan untuk membuat pemotretan realitas sekali jadi. Pemetaan interaktif adalah alat dinamis untuk memahami dan mengevaluasi kondisi setempat dari waktu ke waktu. Oleh karena itu, langkah 3, 4 dan 5 harus diulang-ulang pada interval yang teratur, misalnya setahun sekali.

Manfaat lain dari pemetaan interaktif adalah meningkatkan koordinasi pengumpulan informasi oleh berbagai lembaga.

\section{Menggunakan pemetaan interaktif untuk \\ pemantauan}

- Analisalah peta tema untuk mengetahui ada tidaknya masalah. Adakah daerah yang memerlukan layanan ekstra atau program khusus?

- Lakukan perbandingan antara peta tema saat ini dengan peta tema sebelumnya. Apakah situasinya membaik atau memburuk? Adakah kecenderungan tertentu yang mungkin berarti bahwa masalah bisa terjadi di masa mendatang?

- Dokumentasikan reaksi dan komentar publik atas apa yang mereka lihat di peta. Apa pendapat partisipan tentang kinerja pemerintah daerah? Berdasarkan komentar mereka, bagaimana pemerintah daerah dapat melakukan peningkatan? 


\section{Alat 2:}

Memantau

kesejahteraan

rumah tangga

melalui survei

berdasarkan

indikator lokal

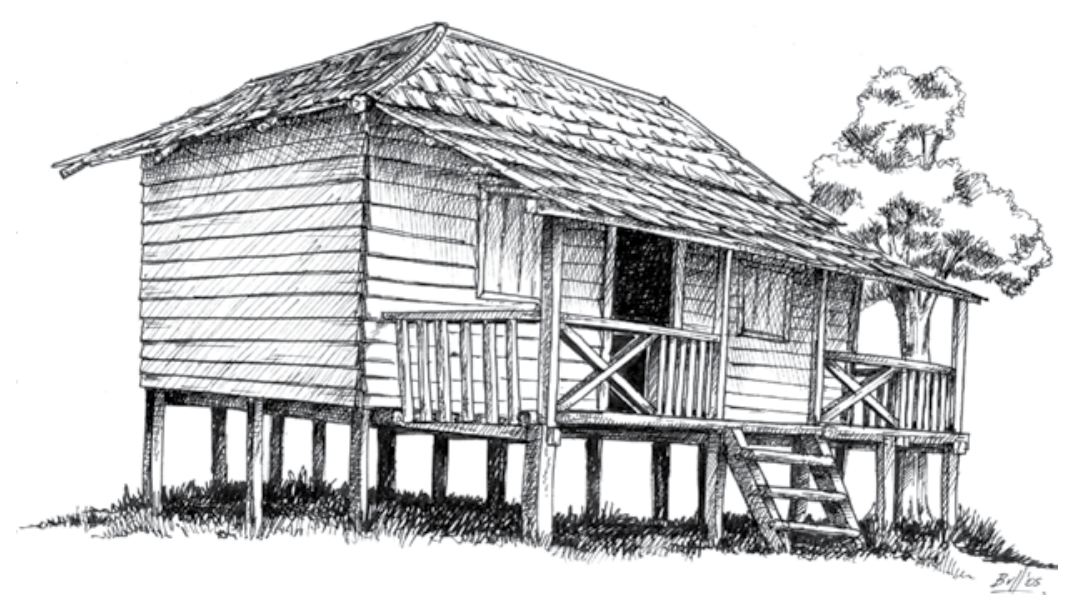

Rata-rata rumah masyarakat di Kalimantan Timur
Apakah sistem pemantauan kesejahteraan lokal itu?

Sistem pemantauan kesejahteraan lokal adalah program yang secara teratur memeriksa dan menganalisa kondisi kemiskinan dan kesejahteraan rumah tangga atau masyarakat. Sistem pemantauan ini disebut 'lokal' karena didasarkan pada konsep kemiskinan dan kesejahteraan lokal dan menggunakan indikator yang bermakna secara lokal.

\section{Mengapa sistem pemantauan kesejahteraan lokal perlu?}

Kemiskinan dan kesejahteraan sering diukur pada tingkat nasional atau internasional. Tetapi sistem pemantauan kesejahteraan lokal memiliki sejumlah keunggulan, seperti:

- Indikator kesejahteraan lokal lebih konkrit;

Kotak 15. Indikator nasional yang tidak cocok

Di Indonesia, rumah tangga yang dinyatakan miskin berdasarkan standar kemiskinan nasional adalah rumah dengan lantai tanah. Tetapi di Kalimantan Timur rumah keluarga paling miskin sekalipun berlantai kayu. Oleh karena itu, indikator kemiskinan nasional tidak otomatis cocok dengan keadaan setempat. Ini merupakan alasan kuat untuk lebih mengutamakan konsep kemiskinan dan kesejahteraan lokal. 
- Sistem pemantauan kesejahteraan lokal menghasilkan data lebih rinci yang relevan dengan budaya dan geografi daerah;

- Sistem pemantauan kesejahteraan lokal dapat lebih terkait dengan isu pembangunan daerah;

- Pemerintah daerah mengembangkan rasa kepemilikan yang lebih kuat terhadap sistem pemantauan mereka.

Akan tetapi memadukan sistem pemantauan kesejahteraan lokal ke dalam program nasional dapat menjadi suatu tantangan tersendiri. Para pengambil keputusan di tingkat nasional mungkin saja menganggap pendekatan tingkat daerah tidak sejalan dengan program pemantauan nasional. Tetapi sebenarnya sistem pemantauan nasional dan daerah dapat saling melengkapi, karena tujuan keduanya berbeda.
Dengan mempertimbangkan alasan di atas, sistem pemantauan kesejahteraan lokal sangat cocok dengan kebutuhan dan tuntutan pemerintah daerah, sementara sistem nasional memberi perbandingan kemiskinan dan kesejahteraan antara berbagai daerah di suatu negara.

\section{Cara menggunakan sistem pemantauan kesejahteraan tokal}

Alat ini terdiri dari deskripsi rinci mengenai cara mengembangkan instrumen survei praktis untuk memantau

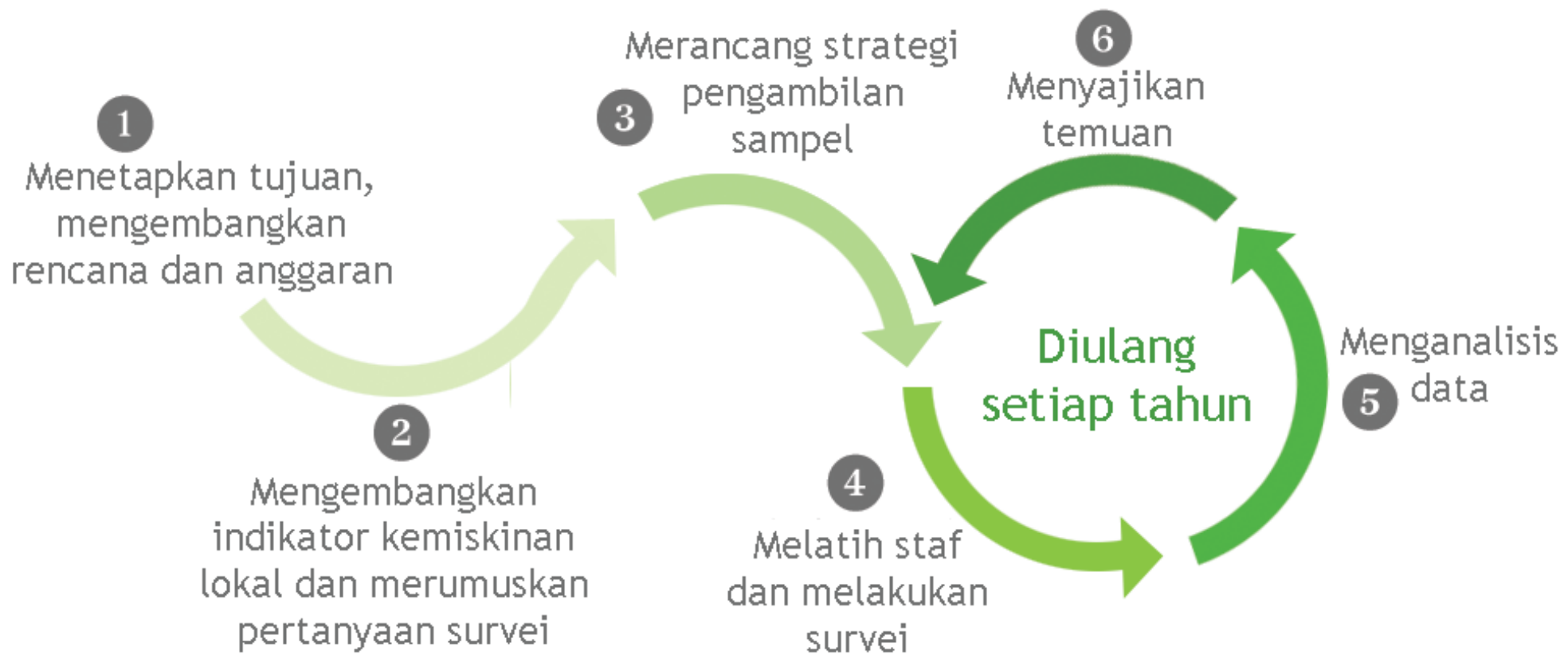

Gambar 9. Langkah-langkah dalam pemantauan kesejahteraan lokal. 
kesejahteraan rumah tangga. Di dalamnya mencakup desain logistik, pengembangan indikator kesejahteraan yang bermakna secara lokal, dan kiat-kiat praktis untuk menerapkan alat ini.

Proses ini diuraikan dalam enam langkah pokok sebagaimana ditunjukkan pada Gambar 9.

Langkah 4, 5 dan 6 harus diulang-ulang secara teratur, misalnya setiap tahun atau setiap dua tahun.

Alat ini dapat diterapkan oleh satu lembaga pemerintah, LSM atau tim pemantau (lihat Kotak 17). Pembentukan akhir dari tim pemantau adalah bagian dari Langkah 1.

\section{Langkah 1. Menetapkan tujuan, mengembangkan rencana dan anggaran}

Merancang program pemantauan memerlukan perencanaan yang cermat. Langkah ini memberi petunjuk tentang cara menyiapkan pengembangan sistem pemantauan kesejahteraan lokal.

\section{A. Menetapkan tujuan pemantauan}

Mengadakan pertemuan dengan para pengambil keputusan pemerintah daerah. Sekalipun pemantauan akan dilakukan oleh

Kotak 16. Mendefinisikan tujuan pemantauan kesejahteraan di Malinau

Para pegawai dari beberapa badan daerah diundang ke lokakarya untuk menetapkan kebutuhan untuk pemantauan kemiskinan di Malinau, Indonesia. Dalam sesi brainstorming, para peserta mengemukakan persepsi masing-masing. Ide-ide ini mendasari tujuan umum pemantauan kemiskinan:

'Memantau tingkat kemiskinan, menilai dampak program pemerintah dan memberikan masukan kepada pemerintah kabupaten untuk mengembangkan program'

\section{Kotak 17. Tim pemantau di Kutai Barat}

Tim pemantau di Kutai Barat dibentuk secara resmi oleh pemerintah kabupaten dan terdiri dari lima pegawai pemerintah yang mewakili dinas pemberdayaan masyarakat, unit sensus demografi, dinas lingkungan, badan perencanaan daerah, dan dinas pertanian, plus satu perwakilan dari LSM lokal. Tim memperoleh beberap pelatihan dan bantuan teknis dari CIFOR dan pelatih dari luar (mengenai penggunaan statistik dan sistem informasi geografis) dalam kurun waktu lebih dari 3 tahun. Tim ini sangat bersemangat, dan mengadakan berbagai uji coba pemantauan dan survei pemantauan resmi secara profesional.

Karena fluktuasi staf yang biasa terjadi, dari waktu ke waktu sebagian anggota diganti karena alasan pindah ke posisi perencanaan yang lebih berpengaruh. Tetapi seusai bupati baru terpilih, kerja tim pemantau terhenti (sementara?).

satu lembaga saja, sebaiknya lembaga-lembaga lain tetap dilibatkan dalam langkah ini. Bantuan mereka dalam seluruh proses mungkin diperlukan, dan mereka mungkin akan menjadi pengguna akhir dari hasil yang diperoleh.

Bahaslah tujuan dari pemantauan kesejahteraan:

- Mengapa pemerintah daerah ingin memantau kesejahteraan?

- Elemen kesejahteraan apa saya yang ingin dipantau pemerintah daerah?

- Apakah tujuannya untuk menetapkan persentase warga miskin di kabupaten atau kotamadya, atau untuk mengidentifikasi setiap rumah tangga miskin?

- Apakah tujuannya untuk melihat sejauh mana rumah tangga mampu memenuhi kebutuhan dasarnya, atau juga untuk mengidentifikasi kondisi yang mempengaruhi 
bagaimana rumah tangga miskin dapat mengentaskan diri dari kemiskinan?

- Apakah pemerintah daerah ingin lebih tepat dalam menyalurkan program bantuan bagi warga miskin, atau ingin meningkatkan perencanaan pembangunan daerah administratif?

Sistem pemantauan yang telah ada sebaiknya dipelajari terlebih dahulu: apa tujuannya, kelompok sasarannya, indikatornya, frekuensinya dan jenis datanya? Dengan penilaian ini akan dapat diketahui apakah pengumpulan data tambahan diperlukan dan juga membantu menghindari pengembangan program yang berlebih-lebihan. Selain itu dengan upaya ini akan dapat disimpulkan apakah sistem pemantauan yang sudah ada dapat ditingkatkan, baik dengan memperbaiki koordinasi antara badan pemerintah, atau dengan pemetaan interaktif seperti pada Alat 1.

\section{B. Menetapkan tingkat detil pemantauan}

Perencanaan harus mencakup pembahasan tentang tingkat detil yang diperlukan. Apakah data kemiskinan diperlukan pada tingkat perorangan, keluarga atau rumah tangga, atau sudah cukup untuk mengidentifikasi masyarakat miskin saja? Keputusan ini membawa dampak yang besar pada bagaimana data dikumpulkan, seberapa banyak informasi yang diperlukan, dan sumber daya yang diperlukan. Semakin detil data yang diperlukan, semakin besar tuntutan pada staf lokal dan anggaran.

Adalah penting untuk bertindak realistis. Program pemantauan yang sederhana tetapi kontinu lebih baik daripada pemantauan yang sangat canggih tetapi jarang diulang atau tidak digunakan sama sekali. Keterbatasan sumber daya mungkin menentukan apakah pemantauan akan diulang setiap tahun, setiap dua tahun atau bahkan pada interval yang lebih panjang.

\section{Mengidentifikasi lembaga pelaksana}

Putuskan badan-badan mana yang akan dilibatkan dalam pemantauan. Jika tujuannya adalah untuk meningkatkan perencanaan pengentasan kemiskinan, akan masuk akal jika pemantauan kemiskinan ini dikaitkan dengan badan perencanaan di tingkat kabupaten atau kotamadya. Jika tujuannya adalah mengidentifikasi keluarga miskin, dinas statistik mungkin akan menjadi badan pelaksana yang tepat.

Keuntungan melibatkan beberapa badan adalah bisa digabungkannya keahlian yang lebih banyak dan sudut pandang yang lebih beragam. Tetapi perlu dipertimbangkan bahwa koordinasi dan kerjasama mungkin akan lebih sulit digalang. Hal yang sama akan terjadi jika LSM dilibatkan.

Solusi praktisnya bisa jadi dengan membentuk tim pemantau yang terdiri dari 4-8 orang perwakilan dari badan pemerintah yang paling berkepentingan. Langkah ini akan memadukan keahlian yang ada dan memfasilitasi komunikasi antar sektor pemerintah. Selain itu, ahli dari luar, seperti dari LSM, badan statistik atau lembaga akademik, sebaiknya diundang jika dirasa perlu. Fungsi utama tim pemantau adalah merancang dan merencanakan sistem pemantauan, memastikan bahwa implementasinya tepat dan menyajikan temuan kepada pemerintah daerah.

\section{Merencanakan anggaran}

Rencanakan anggaran berdasarkan desain program pemantauan. Sumber dana survei dapat mempengaruhi strategi. Jika survei dilakukan dengan menggunakan dana dari pemerintah daerah, memastikan jadwal penyaluran uang. Setiap penundaan administratif dapat mempengaruhi implementasi. Jika terjadi penundaan tak terduga, periode pengumpulan data dapat terdesak ke waktu-waktu yang menyulitkan karena penduduk sibuk dengan kegiatan lain, 
seperti pekerjaan pertanian atau pengumpulan produk hutan, yang berarti semakin sulit menghubungi semua responden.

Langkah 2. Mengembangkan indikator kemiskinan lokal dan merumuskan pertanyaan survei

Bagian ini menjelaskan cara membentuk indikator khas daerah untuk mengukur kemiskinan dan kesejahteraan. Indikator-indikator tersebut selanjutnya digunakan untuk merumuskan pertanyaan survei.

Pendekatan yang diuraikan di sini menggunakan model Nested Spheres of Poverty (NESP) yang dikenalkan di Bagian I. Tinjauan tentang bagian itu mungkin akan membantu sebelum melangkah lebih lanjut.

\section{A. Menetapkan kemiskinan dan kesejahteraan secara lokal}

Atur beberapa diskusi kelompok fokus (lihat Alat 3) untuk membuat definisi lokal tentang kemiskinan dan kesejahteraan.

Kelompok fokus dapat meliputi anggota dari suatu masyarakat, anggota dari sub kelompok dalam masyarakat, seperti kelompok laki-laki, perempuan, pemuda atau kelompok etnis. Keputusan mengenai komposisi kelompok fokus bergantung pada kriteria yang relevan di tingkat lokal yang terkait dengan penghidupan dan kesejahteraan. Kelompok fokus dapat terdiri dari perwakilan pemerintah daerah saja, atau dapat dikelompokkan bersama dengan badan-badan pembangunan dan LSM yang aktif di daerah itu. Pemahaman tentang kemiskinan cenderung berbeda-beda antar kelompok, seperti antara kelompok laki-laki dan perempuan (Kotak 18). Pejabat pemerintah juga sering memiliki pandangan tentang kemiskinan yang berbeda dengan anggota masyarakat.
Selama sesi kelompok fokus, mintalah peserta untuk mengidentifikasi aspek-aspek yang paling penting baik dalam keluarga miskin maupun sejahtera. Jika kelompok fokus tidak memungkinkan, wawancarai beberapa informan kunci yang mewakili masyarakat tersebut.

Setelah tim pemantau memiliki daftar lengkap aspekaspek kemiskinan dan kesejahteraan, selanjutnya aspekaspek tersebut harus diatur dengan menggunakan lingkunganlingkungan dalam model NESP berikut:

- Kesejahteraan subjektif

- Lingkungan inti: kesehatan, kekayaan materi dan pengetahuan

- Lingkungan konteks: lingkungan alam, ekonomi, sosial dan politik, dan prasarana dan layanan.

Jika sebuah lingkungan tidak terwakili dengan baik, fasilitator dapat mengajukan beberapa pertanyaan untuk menentukan apakah ada sebagian aspek yang terlewatkan, atau apakah informan merasa lingkungan tersebut sangat tidak relevan untuk menjelaskan kesejahteraan. Tetapi harap berhati-hati untuk tidak mempengaruhi atau mengarahkan informan.

\section{B. Menyiapkan daftar indikator yang mungkin}

Dengan menggunakan informasi yang terkumpul, tim pemantau harus menyiapkan daftar panjang yang berisi indikator-indikator yang mungkin. Mengingat sebagian indikator mungkin dapat diterapkan secara umum, maka daftar tersebut perlu dicocokkan dengan indikator kemiskinan dari sumbersumber lain, seperti:

- Model kemiskinan dan kesejahteraan nasional dan regional

- Model kemiskinan internasional

- Teori-teori pembangunan

- Prinsip-prinsip pembangunan berkelanjutan;

- Gagasan dari tim pemantau lokal. 


\section{Kotak 18. Perspektif kemiskinan antara laki-laki dan perempuan bisa berbeda}

Gambar 10 menunjukkan hasil diskusi kelompok fokus di 20 desa di Kutai Barat. Di setiap diskusi, peserta dibagi menjadi dua: perempuan dan laki-laki. Setiap kelompok mengemukakan seperangkat faktor berbeda yang dianggap penting untuk mencapai kesejahteraan. Pendidikan, pekerjaan dan penghasilan, kesehatan dan pencegahan bencana samasama diprioritaskan oleh kedua kelompok. Tetapi untuk faktor yang lain, perempuan mengedepankan air bersih dan akses terhadap modal, sementara laki-laki menekankan transportasi dan bantuan pemerintah sebagai faktor yang penting.

\section{Perempuan}

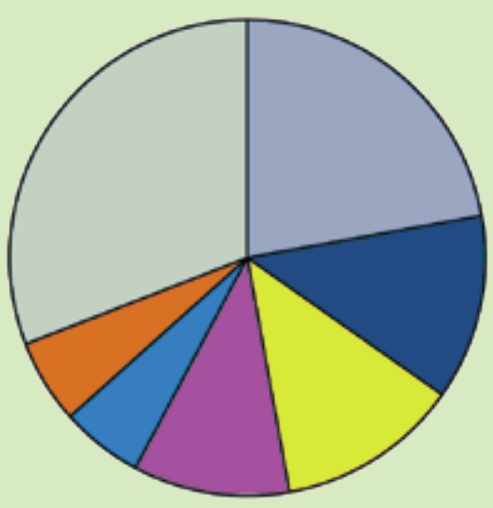

\section{Laki-laki}

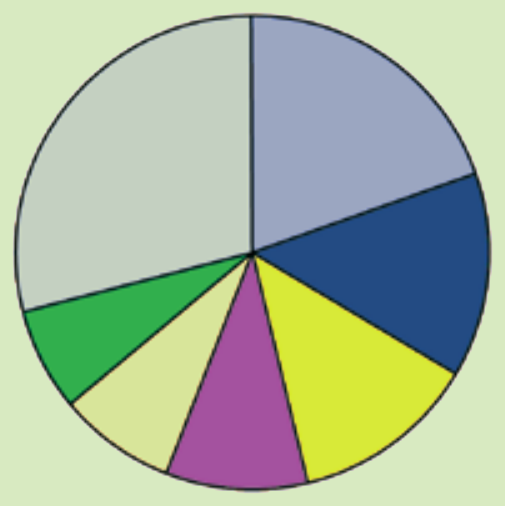

$\square$ Pendidikan

$\square$ Pekerjaan \& penghasilan

\section{$\square$ Kesehatan}

$\square$ Pencegahan bencana

$\square$ Air bersih

$\square$ Modal

$\square$ Bantuan Pemerintah

$\square$ Transportasi

$\square$ Lainnya

Gambar 10. Prioritas kesejahteraan laki-laki dan perempuan di 20 desa, Kutai Barat, Indonesia.

Jika sebagian indikator telah diukur melalui programprogram pemantauan yang ada, hindari duplikasi pekerjaan dan manfaatkan data ini sebaik-baiknya dengan cara melakukan koordinasi dengan program-program tersebut.

Selanjutnya, periksalah indikator untuk memastikan kesesuaiannya dengan kriteria SMART (Kotak 19).

- Simple [Sederhana]: indikator mudah dipahami dan praktis.
- Measurable [Terukur]: indikator dapat dikuantifikasi secara layak dan dapat dinilai dengan menggunakan sarana yang tersedia di daerah (tidak perlu metodologi ilmiah yang mahal).

- Adapted [Sesuai]: indikator bersifat spesifik lokasi; indikator harus relevan dalam konteks sosial budaya dan alam-geografisnya.

- Robust [Kuat]: nilai indikator idealnya tidak bergantung pada siapa penilainya atau kapan penilaian dilakukan 
Kotak 19. Kriteria SMART untuk indikator kemiskinan

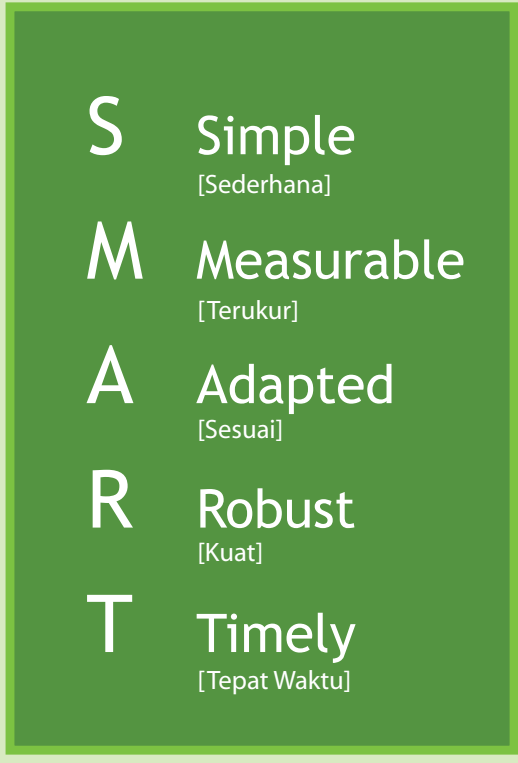

(kecuali jika musim merupakan faktor yang perlu ditangkap). Indikator yang kuat akan dipercaya dan diterima oleh para pembuat keputusan.

- Timely [Tepat Waktu]: indikator mengukur perubahan dalam periode waktu yang wajar. Misalnya, jika horizon rencana adalah satu tahun, tetapi indikator itu hanya berubah setelah 5 tahun, maka indikator tersebut tidak tepat waktu.

Ingat, bahwa indikator kemiskinan hanya berguna selama indikator tersebut terkait dengan penyebab atau kondisi kemiskinan yang mendasarinya. Jika kaitan sebab akibat itu berubah, maka indikator tersebut mungkin tidak lagi relevan dan perlu diganti. Misalnya, jika akses ke sekolah tidak lagi menjadi kendala bagi setiap keluarga, maka diperlukan indikator lain untuk mengukur pendidikan. Sebagai aturan pokok, indikator kemiskinan harus ditinjau setidaknya setiap 5 tahun. Tetapi pertimbangkan perubahan indikator dengan hati-hati. Indikator yang berubah kadang sulit dibandingkan dari waktu ke waktu dan sulit dipakai untuk memantau perubahan. Catat perubahan metode pemantauan sesegera mungkin, karena orang mungkin lupa seiring berlalunya waktu.

Daftar panjang indikator yang diuji dalam proyek kami dapat dilihat secara online di website proyek (http://www. cifor.cgiar.org/indicators).

\section{Menguantifikasi indikator dan merumuskan pertanyaan}

Bahas cara memberi bobot atau menguantifikasi indikator. Data kemiskinan dalam dan lintas masyarakat dapat dibandingkan jika dikuantifikasi. Untuk menguantifikasi indikator, ubahlah indikator menjadi pertanyaan pemantauan dan sediakan dua atau tiga jawaban yang mencakup kisaran dari 'baik' (3 poin), 'sedang' ( 2 poin) hingga 'kritis' (1 poin). Pertanyaan dan jawaban haruslah sederhana, jelas dan tidak rancu. Bahasa setempat sebaiknya digunakan jika warga kesulitan memahami bahasa nasional.

Ingat bahwa setiap pertanyaan harus berupa pertanyaan tertutup (lihat Kotak 20). Pertanyaan tertutup memiliki jumlah jawaban yang terbatas, dan responden harus memilih satu di antaranya. Penggunaan pertanyaan tertutup ini sangat baik karena jawaban akan lebih mudah dibandingkan.

Menyiapkan kuesioner yang baik merupakan seni yang membutuhkan banyak pengalaman. Beberapa pertanyaan mungkin sensitif atau menghasilkan jawaban yang bias. Misalnya, orang mungkin enggan menjawab pertanyaan tentang pendapatan tahunan mereka, atau mungkin tidak bisa menyebutkan jumlahnya secara akurat. Tetapi mereka tidak akan terlalu kesulitan untuk menjawab pertanyaan tentang besarnya pengeluaran terbaru atau biaya hidup. 
Kotak 20. Cara mengubah indikator menjadi pertanyaan-Contoh dari Malinau

Tim pemantau di Malinau menyepakati beberapa indikator berikut untuk mengukur kekayaan:

1. Aset materiil (sepeda motor atau perahu motor, gergaji mesin atau kulkas)

2. Kondisi rumah (kondisi umum, listrik, toilet)

3. Pembelian baju baru tahunan

Indikator ini kemudian diterjemahkan menjadi pertanyaan untuk survei kemiskinan, sebagai berikut.

\section{Aset materiil}

Apakah rumah tangga ini memiliki:

perahu motor atau sepeda motor? 1 tidak, 3 ya gergaji mesin atau kulkas? 1 tidak, 3 ya

\section{Kondisi rumah}

Apakah rumah (petugas survei langsung mengobservasi, tidak perlu bertanya):

1 Di bawah standar setempat,

2 Standar setempat,

3 Di atas standar setempat

Apakah ada listrik di rumah?

1 tidak,

2 ya, tetapi tidak berfungsi,

3 ya dan berfungsi

Apakah di dalam rumah terdapat toilet?

1 tidak,

3 ya

\section{Baju baru}

Selama setahun terakhir, adakah anggota keluarga yang membeli baju baru?

$$
\begin{aligned}
& 1 \text { tidak, } \\
& 2 \text { ya, 1-2 kali, } \\
& 3 \text { ya, > } 2 \text { kali }
\end{aligned}
$$

Untuk menghindari bias semacam ini, pemerintah daerah harus mencari bantuan eksternal dari ilmuwan sosial yang berpengalaman, dinas statistik pemerintah, universitas atau LSM.

\section{Memperpendek daftar indikator}

Indikator yang banyak memberi cakupan informasi yang lebih luas. Tetapi indikator yang terlalu banyak akan menjadikan wawancara panjang dan melelahkan dan analisis yang lebih rumit. Tiga indikator per lingkungan kesejahteraan sudah ideal. Karena ada sembilan lingkungan, jumlah keseluruhan indikator berarti 27 . Berarti terdapat 27 pertanyaan yang dapat diajukan secara wajar dalam wawancara selama sekitar 30 menit.

Gunakan uji lapangan untuk memperpendek daftar panjang asli yang disiapkan pada langkah 2B. Pilih 5-10 desa dengan ukuran, komposisi etnis dan lokasi yang beragam. Siapkan kuesioner lengkap dengan semua indikatornya, dan ujikan pada masyarakat tadi dengan menggunakan teknik survei standar.

Lalu, kelompokkan hasilnya menurut lingkunganlingkungan kesejahteraan. Misalnya, gabungkan data dari semua pertanyaan terkait dengan kesehatan, data dari semua pertanyaan terkait dengan pengetahuan dan seterusnya. Jumlahkan semua gabungan skor per lingkungan (kesehatan 
adalah satu lingkungan, pengetahuan satu lingkungan - lihat Bagian I) menjadi satu angka, hingga terdapat sembilan angka yang mewakili sembilan lingkungan dalam model NESP.

Selanjutnya, hitung subtotal dengan menjumlahkan data dari kombinasi tiga pertanyaan yang berbeda yang terkait dengan satu lingkungan, karena pada akhirnya Anda hanya memerlukan tiga indikator per lingkungan. Ujilah subtotal dari kombinasi pertanyaan yang berbeda tersebut dengan menggunakan uji korelasi (misal, uji korelasi tingkat Spearman) dengan nilai total untuk semua rumah tangga.

Pilih subtotal yang menunjukkan tingkat korelasi tertinggi dengan daftar lengkap (fullset) untuk setiap lingkungan (idealnya koefisien korelasi, $r$, harus lebih besar daripada 0,8). Korelasi yang tinggi menunjukkan bahwa subset tersebut mewakili fullset, karena sebagian indikator berkorelasi dengan indikator lainnya. Misalnya, rumah tangga yang memiliki antena parabola hampir pasti juga memiliki TV dan akses ke listrik. Jadi, 'memiliki antena parabola' bisa menjadi indikator yang sebenarnya mewakili ketiga indikator uji.

Ingat bahwa uji statistik bukanlah satu-satu cara yang diperlukan untuk mendapatkan pemahaman. Gunakan penilaian intuitif saat menganalisa set indikator yang lebih kecil. Statistik memang berguna, tetapi tidak dapat menggantikan penalaran. (Lihat Kotak 21).

\section{Langkah 3. Merancang strategi pengambilan sampel}

Strategi pengambilan sampel (sampling) tergantung oleh tujuan pemantauan dan sumber daya yang tersedia. Sampling yang rinci pada tingkat rumah tangga akan menghasilkan data yang paling akurat dan informasi yang paling banyak, tetapi untuk itu diperlukan cukup dana, waktu dan staf yang cakap. Jika gambaran yang kurang rinci sudah cukup, pemerintah daerah mungkin memutuskan untuk mempelajari kemiskinan pada tingkat desa, bukan keluarga.

\section{A. Menetapkan unit sampling}

Tentukan apakah rumah tangga atau desa yang dijadikan unit sampling Jika rumah tangga yang dipilih, lakukan survei rumah tangga dengan menggunakan kuesioner standar.

Jika unit samplingnya adalah tingkat desa, gunakan diskusi kelompok fokus. Selalu ingat bahwa kedua teknik ini memerlukan kecakapan dan pengalaman yang berbeda. Jika kelompok fokus digunakan, pertimbangkan untuk meminta bantuan dari LSM yang memiliki fasilitator terlatih. Contoh penggunaan diskusi kelompok fokus dijelaskan pada Alat 3.

\section{B. Memilih desa}

Dalam program pemantauan kemiskinan, cobalah melibatkan semua masyarakat untuk menghindari risiko terbentuknya gambaran yang salah. Jika tidak mungkin, pilihlah masyarakat yang mewakili keragaman seluruh populasi secara memadai.

Saat memilih masyarakat, pertimbangkan apakah kesukuan, ukuran desa, keterjangkauan, ketergantungan pada sumber daya hutan atau faktor-faktor lainnya akan mempengaruhi kesejahteraan dan kemiskinan pada sampel. Metode sampling berdasarkan tujuan (purposive sampling) ini akan efektif jika ia selaras dengan tujuan survei. Tetapi pola yang muncul dari sampling ini bersifat kurang pasti dan tidak pernah menghasilkan data dengan kualitas yang sama dengan survei yang mencakup semua desa. Misalnya, jika masalah kesehatan terdeteksi di suatu desa, metode ini akan mengarah pada kesimpulan bahwa semua desa dalam kelompok yang sama memiliki masalah serupa, padahal sebenarnya mungkin tidak demikian. 
Kotak 21. Mengurangi jumlah indikator kesehatan

Di Kutai Barat, kami menggunakan 11 indikator tes dari daftar panjang kami untuk kesehatan dan gizi: (1) konsumsi protein hewani, (2) kekurangan protein hewani, (3) konsumsi nasi, (4) kekurangan nasi, (5) ketersediaan air minum bersih, (6) anggota keluarga yang sakit, (7) penyakit kronis, (8) anak-anak dengan panjangberat badan di bawah indeks kritis, (9) perawatan yang tersedia, (10) kematian bayi, (11) kematian ibu melahirkan.

Kami menilai indikator-indikator ini melalui uji coba di delapan komunitas. Selanjutnya kami menguji korelasi antara ke-11 subset dengan fullset. Kami juga menggabungkan beberapa indikator tes menjadi satu indikator baru, misalnya 'kekurangan protein hewani' dan 'kekurangan nasi' digabungkan menjadi 'kekurangan makanan' (selama periode setidaknya satu bulan). Kombinasi dengan korelasi tertinggi adalah: 'konsumsi protein' 'kekurangan makanan' dan penyakit parah' dengan koefisien korelasi $r=0.889$.

Tetapi dalam sistem pemantauan akhir, kami memodifikasi set indikator tersebut sekali lagi karena tim pemantau percaya bahwa indikator 'ketersediaan air minum bersih' terlalu penting untuk ditinggalkan (meskipun korelasinya agak rendah, $r=0.858$ ).
Daftar pendek indikator kemiskinan yang digunakan di Kutai Barat, 2006

\begin{tabular}{|c|c|c|}
\hline & $\begin{array}{l}\text { Lingkungan } \\
\text { kesejahteraan }\end{array}$ & Indikator kesejahteraan† \\
\hline $\begin{array}{l}S \\
J \\
S\end{array}$ & $\begin{array}{l}\text { Kesejahteraan } \\
\text { subjektif }\end{array}$ & $\begin{array}{l}\text { Perasaan bahagia } \\
\text { Perasaan sejahtera } \\
\text { Perasaan miskin }\end{array}$ \\
\hline $\begin{array}{l}\mathrm{I} \\
\mathrm{N} \\
\mathrm{T} \\
\mathrm{I}\end{array}$ & $\begin{array}{l}\text { Kesehatan } \\
\text { Kekayaan } \\
\text { materi } \\
\text { Pengetahuan }\end{array}$ & $\begin{array}{l}\text { Kekurangan makanan lebih dari satu bulan } \\
\text { Akses air minum bersih } \\
\text { Akses ke fasilitas dan layanan kesehatan } \\
\text { Kondisi rumah yang layak } \\
\text { Barang materi minimum: sepeda motor/perahu motor } \\
\text { Barang materi minimum: antena parabola/kulkas } \\
\text { Jenjang pendidikan formal tertinggi di rumah tangga } \\
\text { Kehadiran di sekolah } \\
\text { Pengetahuan/keterampilan informal }\end{array}$ \\
\hline $\begin{array}{l}\mathrm{K} \\
\mathrm{O} \\
\mathrm{N} \\
\mathrm{T} \\
\mathrm{E} \\
\mathrm{K} \\
\mathrm{S}\end{array}$ & $\begin{array}{l}\begin{array}{l}\text { Lingkungan } \\
\text { ekonomi }\end{array} \\
\text { Lingkungan } \\
\text { sosial } \\
\text { Lingkungan } \\
\text { politik } \\
\text { Prasarana \& } \\
\text { Pelayanan }\end{array}$ & $\begin{array}{l}\text { Gangguan alam secara umum } \\
\text { Keberadaan burung enggang atau bangau tongtong } \\
\text { Eksploitasi sumber daya alam secara berlebihan } \\
\text { Kualitas air secara umum } \\
\text { Jumlah sumber pendapatan } \\
\text { Stabilitas/keandalan sumber pendapatan } \\
\text { Persediaan beras/kemampuan membeli beras } \\
\text { Akses untuk mendapatkan modal (kredit, pinjaman) } \\
\text { Tingkat kerjasama } \\
\text { Rasa saling percaya } \\
\text { Tingkat konflik } \\
\text { Hak penggunaan sumber daya \& akses ke sumber daya } \\
\text { Akses informasi } \\
\text { Partisipasi politik dalam pengambilan keputusan } \\
\text { Akses ke sekolah menengah } \\
\text { Kualitas layanan pendidikan } \\
\text { Akses ke fasilitas kesehatan dasar } \\
\text { Kualitas layanan kesehatan } \\
\text { Kondisi jalan dan jembatan } \\
\text { Akses ke pasar } \\
\text { Akses ke fasilitas komunikasi }\end{array}$ \\
\hline
\end{tabular}

$\dagger$ Ingat, untuk beberapa lingkungan lebih dari 3 indikator digunakan agar lebih komprehensif. 
Jika sampling berdasarkan tujuan digunakan, jadwalkan pembahasan dengan tim pemantau untuk meninjau hasil-hasil dan menilai kualitas dan akurasi datanya.

\section{Memilih responden untuk wawancara rumah tangga}

Jika jumlah rumah tangga dalam suatu desa kurang atau sama dengan 20 , lakukan survei terhadap semua rumah tangga. Jika terdapat 21-60 rumah tangga dalam suatu desa dan jika populasinya homogen serta tidak memiliki pola penyebaran rumah tangga yang khusus, maka pilihlah 20 rumah tangga secara acak (misalnya dengan menuliskan kesemua rumah tangga yang ada pada selembar kertas kemudian memilih 20 secara acak). Jika ada lebih dari 60 rumah tangga dalam suatu masyarakat, lakukan survei terhadap sepertiganya untuk mendapatkan sampel yang representatif.

Ada banyak cara melakukan sampling acak. Salah satunya adalah dengan memetakan dan menomori semua rumah tangga dalam suatu desa, kemudian secara acak memilih salah satu dari ketiga rumah pertama kemudian selanjutnya dengan cara lompat tiga. Misalnya, sampel adalah rumah tangga nomor 1 , 4, 7, 10 dst. (lihat Kotak 22). Jika mungkin, mintalah petunjuk profesional dari dinas statistik pemerintah untuk strategi sampling yang paling cocok.

\section{Langkah 4. Melatih staf dan melakukan survei}

\section{A. Melatih staf}

Kembangkan program pelatihan staf. Pelatihan harus mencakup teknik wawancara dan penanganan data. Jenis pelatihan tergantung pada detil pengumpulan data dan metode yang digunakan.

\section{Kotak 22. Memilih rumah tangga di Kutai} Barat

Kami menggunakan peta sketsa sederhana di Kutai Barat untuk menentukan sample sepertiga dari semua rumah tangga yang ada (Gambar 11). Kami memilih satu rumah, melewati dua rumah berikutnya, memilih satu rumah berikutnya, melewatidua berikutnya danseterusnya.
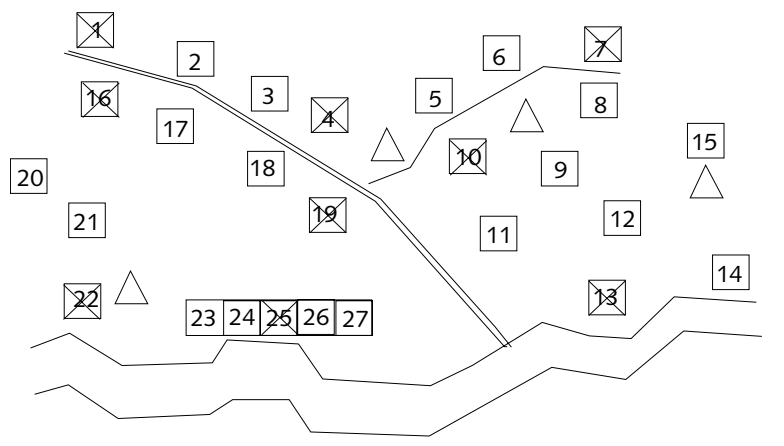

$$
\text { (29) }
$$

Gambar 11. Contoh pemilihan responden. Rumah tangga yang dipilih diberi tanda $X$ di dalam persegi empat yang diberi nomor 
Jika jumlah desa dan respondennya kecil, mungkin cukup untuk melatih satu tim survei saja. Jika survei mencakup desa yang banyak, daerah yang luas dan responden yang banyak, selenggarakan 'pelatihan bagi para pelatih' (Training of Trainers). Para pelatih ini selanjutnya dapat menyiapkan timtim survei untuk melakukan pengumpulan data.

Waktu merupakan aspek yang penting. Jika rentang waktu antara pelatihan dan survei terlalu lama, kualitas data akan berkurang. Jika survey dilakukan secara teratur, adakan sesi pelatihan penyegaran sebelum setiap survei untuk menjaga kualitas.

B. Memberikan tanggung jawab pengumpulan, pemrosesan dan analisis data

Tetapkan tanggung jawab yang jelas dalam tim. Ini penting untuk kelancaran pelaksanaan survei. Awasi penggunaan dana dengan cermat. Cermati biaya transportasi dan akomodasi yang ada, serta biaya-biaya lainnya. Anggaran untuk survei sering terbatas, oleh karena itu pemanfaatan dana secara efisien merupakan hal yang sangat penting.

Untuk tim survei, kompensasi berdasarkan insentif dapat membantu. Misalnya, di Kutai Barat, pengumpul data menerima honor untuk setiap lembar wawancara yang diisi. Tetapi pastikan melakukan tindak lanjut ke lapangan dan memeriksa ulang pengumpulan data untuk mengurangi penyalahgunaan insentif dan untuk memverifikasi kualitas.

Setelah pengumpulan data selesai, susun data untuk diproses dan dianalisa. Pemerintah daerah mungkin tidak memiliki pengetahuan teknis tentang pemrosesan data. Dalam hal ini, mengadakan pelatihan tambahan atau mengalih-dayakan entri data dan analisisnya.
Tetapi masalahnya, staf yang terlatih mungkin ganti posisi atau dipindahkan ke dinas pemerintah yang lain. Selain itu, cobalah mengadakan pelatihan untuk anggota masyarakat, misalnya, untuk menjadi pendata pemantauan. Langkah ini akan meningkatkan kapasitas lokal.

Jika pemrosesan dan analisis data dialihdayakan, sebutkan dengan jelas informasi apa yang harus disediakan oleh pihak penganalisis data. Awasi proses ini secara cermat.

\section{Langkah 5. Menganalisa dan menyajikan data}

Hasil survei hanya akan berguna jika disajikan dalam format yang jelas dan bermakna. Salah satu cara melakukannya adalah dengan membuat indeks untuk setiap sektor pemerintah atau lingkungan kemiskinan. Indeks adalah angka tunggal yang menggabungkan informasi dari semua pertanyaan yang berhubungan dengan suatu topik. Indeks mudah dipahami

\section{Kotak 23. Menghitung indeks kesehatan}

Lingkungan kesehatan di Kutai Barat terdiri dari tiga indeks: 'kekurangan makanan' 'ketersediaan air minum bersih' dan ákses ke layanan kesehatan' (lihat Kotak 21). Masing-masing indikator memiliki rentang nilai 1 sampai 3. Bila semua nilai itu dijumlahkan, nilai maksimalnya adalah 9 dan minimalnya 3. Rumus berikut dapat digunakan untuk menormalisasi nilai (menempatkannya antara 0 dan 1):

(total nilai - nilai minimal) / (nilai maksimal - nilai minimal)

Bila, misalnya, rata-rata nilai indikator pada suatu masyarakat adalah:

Kekurangan makanan: 1,75

Ketersediaan air minum bersih: 2,23

Akses ke layanan kesehatan: 1,95

Maka nilai indeksnya adalah :

$(1,75+2,23+1,95-3) /(9-3)=0,488$ (atau 48,8\% dari nilai maksimal). 
karena merangkum hasil dari banyak pertanyaan ke dalam satu angka. Contohnya adalah indeks kesehatan, yang dapat menggabungkan hasil dari beberapa pertanyaan tentang kesehatan.

\section{A. Menghitung indeks untuk setiap lingkungan}

Untuk membuat indeks, tambahkan nilai ( 3 poin untuk 'baik', 2 untuk 'sedang' dan 1 untuk 'kritis') dan normalisasikan agar pertanyaan dapat dibandingkan satu dengan yang lain (lihat Kotak 23).

Hitunglah indeks untuk setiap lingkungan. Sajikan hasilnya secara grafis untuk membantu pengguna memvisualisasikan hasil-hasil tersebut (lihat Kotak 23). Ilustrasi untuk lingkungan kesehatan dapat dilihat pada Kotak 23. Semua jawaban pertanyaan tentang kesehatan dalam survei yang dilakukan di Kutai Barat ini digabung ke dalam satu indeks.

\section{B. Menyajikan indeks dalam bentuk tabel}

Setelah semua indeks lingkungan kesejahteraan dihitung, tibalah saatnya menyajikan hasil pemantauan kepada para pembuat keputusan. Ada banyak cara untuk menyajikan data. Salah satu cara untuk membandingkan desa secara kuantitatif adalah dengan mencantumkan indeks-indeks lingkungan kesejahteraan di dalam tabel sederhana. Gunakan warna untuk menunjukkan lingkungan mana yang kritis, sedang atau baik.

Kotak 24 menunjukkan indeks yang dihitung dari indikatorindikator pada setiap lingkungan.

Kotak 24. Daftar data dengan kode warna (nama desa bukan nama sebenarnya)

$\begin{array}{lccccccccc}\text { Masyarakat } & \text { SJS } & \text { KS } & \text { M } & \text { PGT } & \text { A } & \text { E } & \text { S } & \text { P } & \text { P\&P } \\ \text { Durian } & 0,52 & 0,67 & 0,49 & 0,48 & 0,75 & 0,48 & 0,60 & 0,43 & 0,67 \\ \text { Rambutan } & 0,53 & 0,55 & 0,70 & 0,51 & 0,86 & 0,61 & 0,63 & 0,49 & 0,71 \\ \text { Kelapa } & 0,27 & 0,56 & 0,32 & 0,46 & 0,88 & 0,62 & 0,58 & 0,49 & 0,71 \\ \text { Mangga } & 0,03 & 0,31 & 0,33 & 0,37 & 0,72 & 0,35 & 0,38 & 0,33 & 0,35 \\ \text { Lai } & 0,57 & 0,90 & 0,54 & 0,44 & 0,91 & 0,92 & 0,53 & 0,41 & 0,81 \\ \text { Jeruk } & 0,25 & 0,40 & 0,48 & 0,39 & 0,75 & 0,42 & 0,59 & 0,41 & 0,36 \\ \text { Salak } & 0,38 & 0,40 & 0,44 & 0,31 & 0,70 & 0,66 & 0,74 & 0,75 & 0,46 \\ \text { Pisang } & 0,32 & 0,35 & 0,41 & 0,33 & 0,43 & 0,56 & 0,53 & 0,40 & 0,39 \\ \text { Jambu } & 0,25 & 0,58 & 0,51 & 0,36 & 0,56 & 0,67 & 0,53 & 0,51 & 0,33\end{array}$

Catatan: Merah = kritis; kuning = sedang; hijau = baik.

SJS = kesejahteraan subjektif; $\mathrm{KS}=$ kesehatan; $M=$ materi; $\mathrm{PGT}=$ pengetahuan;

$\mathrm{A}=$ lingkungan alam; $\mathrm{E}$ = lingkungan ekonomi; $\mathrm{S}=$ lingkungan sosial; $\mathrm{P}=$ lingkungan politik; P\&P = prasarana dan pelayanan. 


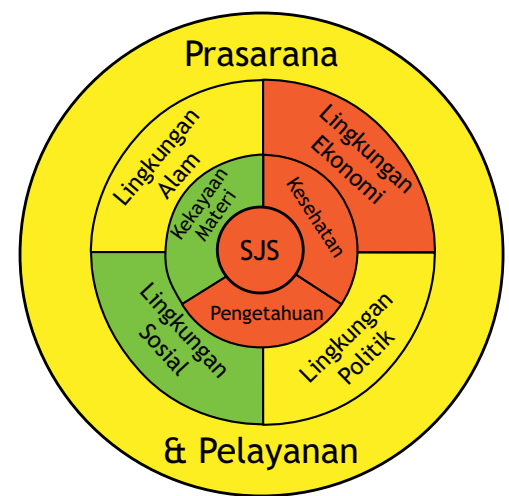

Desa A

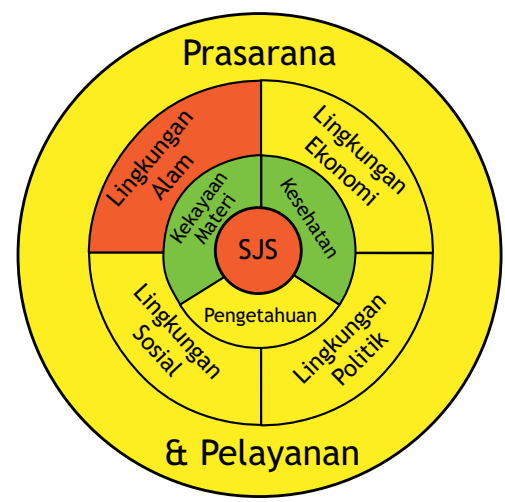

Desa C

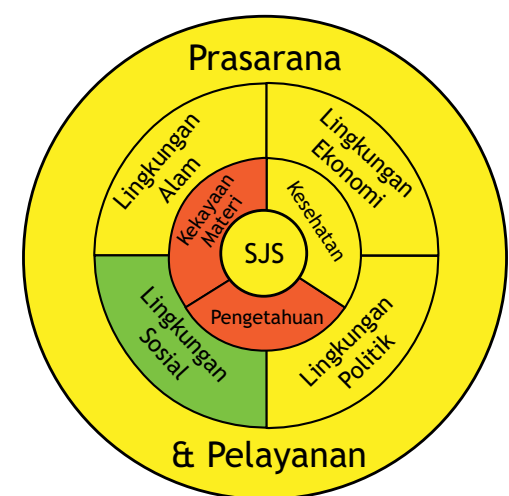

Desa B

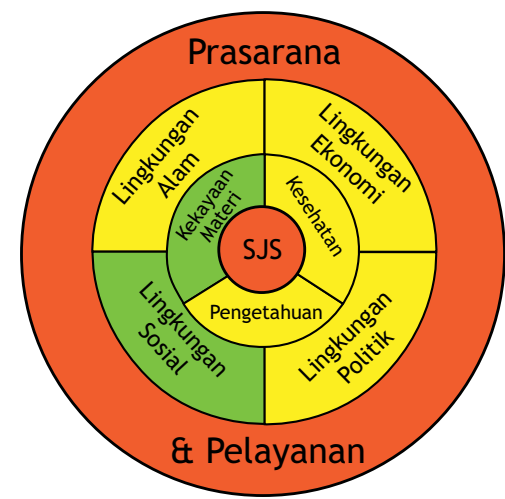

Desa D

Gambar 12. RepresentasiNESP untuklingkungankesejahteraan/kemiskinan pada empatmasyarakat diKutai Barat(Februari-Maret 2006).

Kode warna menunjukkan apakah suatu indeks dalam keadaan kritis, sedang atau baik. Batas antara ketiga warna ini tergantung pada kisaran nilai indikator untuk setiap lingkungan. Beberapa indikator bisa hanya memiliki 2 kemungkinan nilaiskor 1 (kritis) dan 3 (baik)-sedangkan indikator yang lain memiliki 3-ditambah skor 2 (sedang). Jadi batas untuk kritis (merah) adalah antara 0,333 (jika semua indikator berada pada kisaran 1-3) dan 0,5 (jika nilainya hanya 1 dan 3, tanpa 2) tergantung pada lingkungan masing-masing.

\section{Menyajikan hasil dalam format NESP atau diagram batang}

Tidak setiap orang suka membaca tabel. Jika Anda ingin menyajikan hasil dengan cara yang lebih menarik, gunakan model NESP (lihat Bagian 1) atau diagram batang. Model NESP memungkinkan pengguna untuk membandingkan rumah tangga, desa atau kecamatan secara sekilas (lihat Gambar 13 dan 14 untuk contoh dari Kutai Barat pada tahun 2006). 


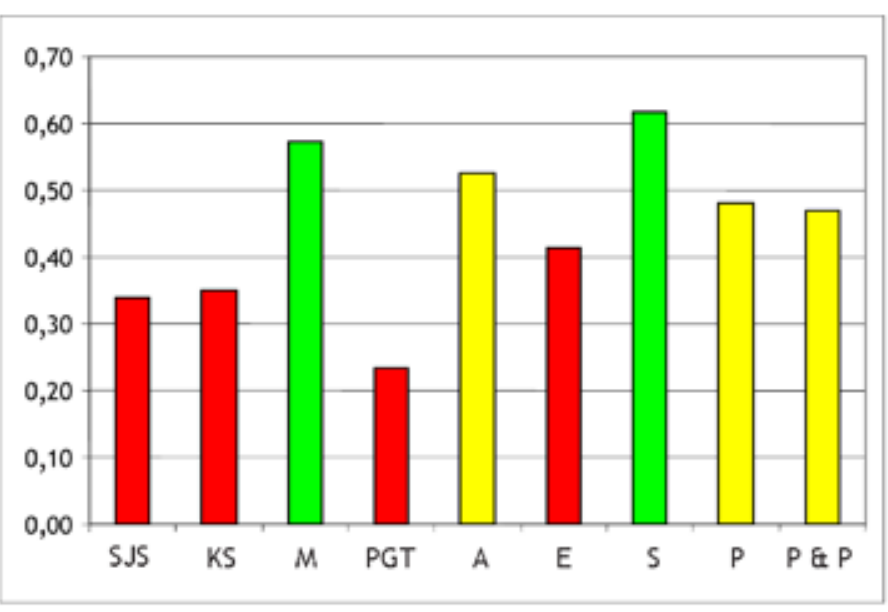

Desa A

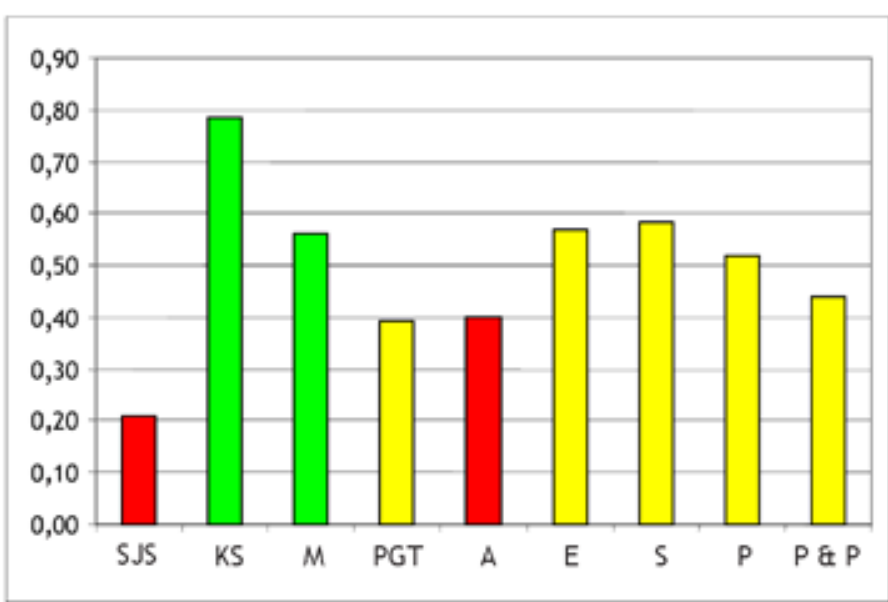

Desa C

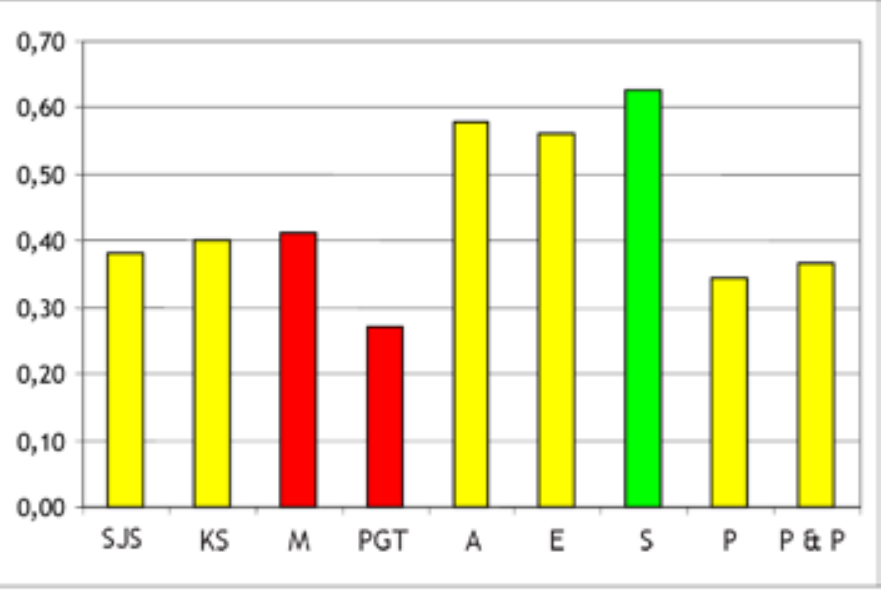

Desa B

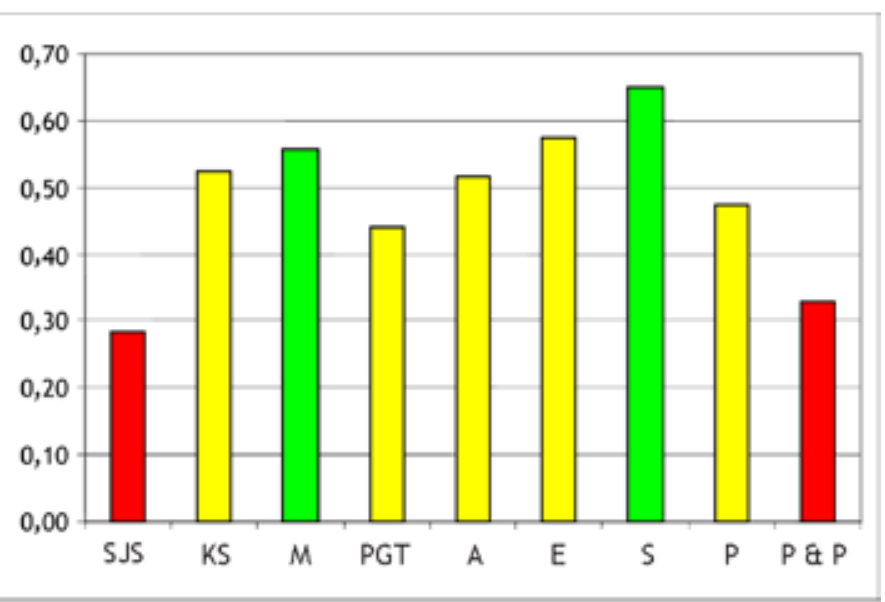

Desa D

Gambar 13. Diagram batang untuk skor lingkaran kemiskinan pada 4 desa yang sama dengan yang ditampilkan pada Gambar 12 (Singkatan mengikuti Kotak 24). 
Setiap grafis penyajian data kemiskinan memiliki kekuatan dan kelemahan.

NESP memberi tinjauan ringkas tentang situasi kemiskinan di suatu desa (atau rumah tangga atau kecamatan, dll), termasuk sektor-sektor yang kritis dan kemungkinan imbangannya. Diagram batang menunjukkan gambaran yang lebih terinci, yang memungkinkan perbandingan indeks dengan kode warna yang sama secara lebih kuantitatif. Kedua versi ini bisa dengan cepat menunjukkan sektor-sektor mana yang dalam kondisi kritis. Pada contoh diagram batang Gambar 13, desa A kekurangan pengetahuan dan layanan kesehatan dan memiliki masalah pada lingkungan ekonomi, desa B kekurangan pengetahuan, desa $C$ tampak jelas memiliki masalah lingkungan, sedangkan desa $D$ mengalami kekurangan prasarana dan pelayanan pemerintah. Semua lingkungan merah ini adalah sinyal waspada bagi instansi pemerintah terkait yang perlu ditindaklanjuti dengan analisis yang lebih mendalam mengenai penyebab yang mendasarinya.

Saat meninjau hasil-hasil ini, ingat selalu bahwa tidak ada pembedaan alami antara desa miskin dan tidak miskin. Setiap garis kemiskinan didasarkan pada definisi kemiskinan tertentu. Pada contoh ini, tim pemantau lokal mendefinisikan 'miskin' (skor 1 atau warna merah) dengan menggunakan konsep kemiskinan dan kesejahteraan setempat (lihat Langkah 2A). Akan tetapi definisi ini tidak permanen. Jika standar kehidupan berubah, makna dari apa yang pantas diberi skor kritis juga akan berubah.

\section{Membuat peta kemiskinan}

Peta kemiskinan menunjukkan lokasi hotspot kemiskinan. Gambar 15 dan 16 menunjukkan peta kemiskinan yang dibuat untuk Kutai Barat. Buatlah peta kemiskinan untuk setiap lingkungan kesejahteraan dengan menempatkan hasil survei per desa pada sebuah peta (lihat Alat 1 untuk deskripsi lebih lengkap tentang proses ini).
Peta kemiskinan membantu menjawab pertanyaan ' $D i$ mana warga miskin berada?' Tetapi pola yang terungkap melalui peta kemiskinan ini tidak serta-merta memberi jawaban terhadap masalah 'Mengapa mereka miskin?’ Peta ini hanya dapat menunjukkan korelasi antara berbagai aspek kemiskinan. Kendati demikian, korelasi ini merupakan titik awal yang baik untuk memahami penyebab yang mendasari kemiskinan.

\section{Langkah 6. Menyajikan temuan}

Setelah mengumpulkan dan menganalisa data pemantauan kemiskinan, sajikan temuannya kepada masyarakat dan kemudian bahaslah pertanyaan berikut:

- Bandingkan temuan ini dengan pengalaman hidup nyata mereka. Apakah data ini mencerminkan situasi sebenarnya?

- Bandingkan hasil dari masyarakat mereka dengan masyarakat tetangga. Mengapa ada perbedaan?

- Apakah hasil ini berguna untuk memahami kemiskinan? Bahas bagaimana mereka dapat menggunakan informasi ini. Anjurkan agar mereka menggunakan hasil ini untuk mengidentifikasi prioritas pembangunan masyarakat dan menguatkan rencana tindakan untuk tahun-tahun mendatang. Contoh tindak lanjut berbasis masyarakat setelah dilakukannya pemantauan kemiskinan dan kesejahteraan di Kutai Barat (menggunakan model NESP) diuraikan pada Kotak 25. Anjurkan agar masyarakat berpartisipasi dalam perencanaan berbasis skenario (lihat Alat 4).

Sampaikan hasil ini kepada pemerintah daerah:

- Sajikan temuan ini kepada pejabat pemerintah daerah dalam sebuah lokakarya. Bahas cara memenuhi kebutuhan dari berbagai dinas atau sektor yang berlainan. Dorong terjadinya diskusi informal antara pejabat di sektorsektor yang berbeda. Mengidentifikasi kebutuhan koordinasi. 
- Buat dan sebarkan laporan tertulis.

- Pastikan data mudah diakses oleh siapa saja yang ingin mendapatkan informasi tambahan sepanjang tahun berjalan.

Gambar 14. Aspek kesehatan dari kemiskinan di Kutai Barat, 2006. Setiap titik berwarna mewakili situasi kemiskinan di suatu desa.

Gambar 15. Kondisi aspek lingkungan alam, Kutai Barat, 2006.

Setiap titik berwarna mewakili kondisi lingkungan alam pada suatu desa.
Aspek Kesehatan dari Kemiskinan

Kutai Barat 2006

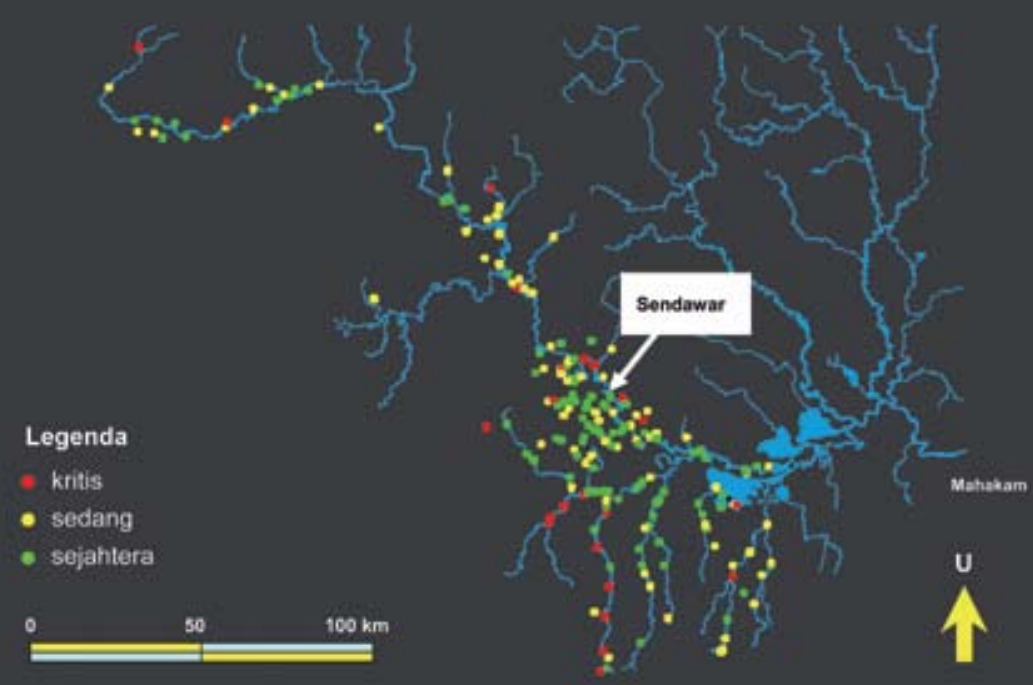

Lingkungan Alam

Kutai Barat 2006

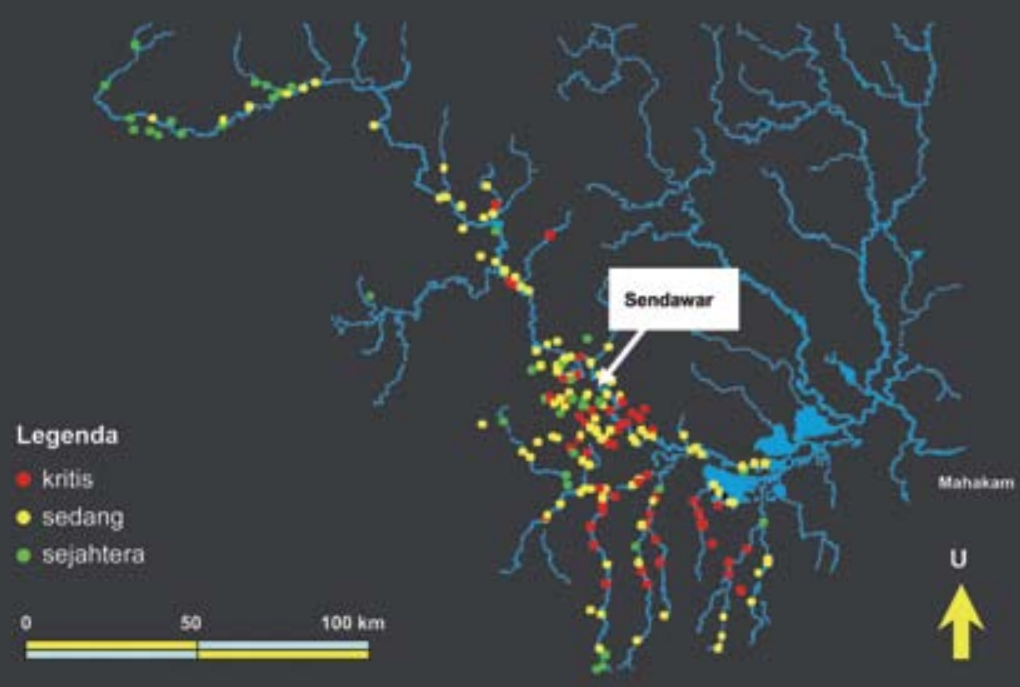


Kotak 25. Perencanaan pembangunan berbasis indikator kemiskinan lokal di tingkat masyarakat dan kecamatan

Seusai melakukan survei kesejahteraan rumah tangga di Kutai Barat (2006), kami melaporkan balik hasilnya kepada masyarakat. Anggota masyarakat awalnya membahas keabsahan datanya dan kemudian menggunakan diagram warna kemiskinan-kesejahteraan untuk mengidentifikasi aspek kesejahteraan yang paling kritis. Mereka membahas penyebab masalah kemiskinan tersebut dan menyusun rencana tindakan satu tahun serta menyerahkannya kepada sesi perencanaan kecamatan.

Beragam usulan diulas di tingkat kecamatan dan masalah antar desa, seperti polusi sungai dan akses jalan yang buruk, dibahas untuk mencari solusinya bersamasama. Mereka mengecek kegiatan yang diusulkan masyarakat berdasarkan prioritas pembangunan hasil survei dan analisis NESP, dan mempelajari landasan pemikiran yang dikemukakan masyarakat. Pemerintah kemudian mengembangkan rencana pembangunan tahunan kecamatan yang mencerminkan prioritas yang jadi sasaran dan sumber daya yang tersedia.

Gambar 16 menunjukkan siklus pemantauan dan perencanaan utama.

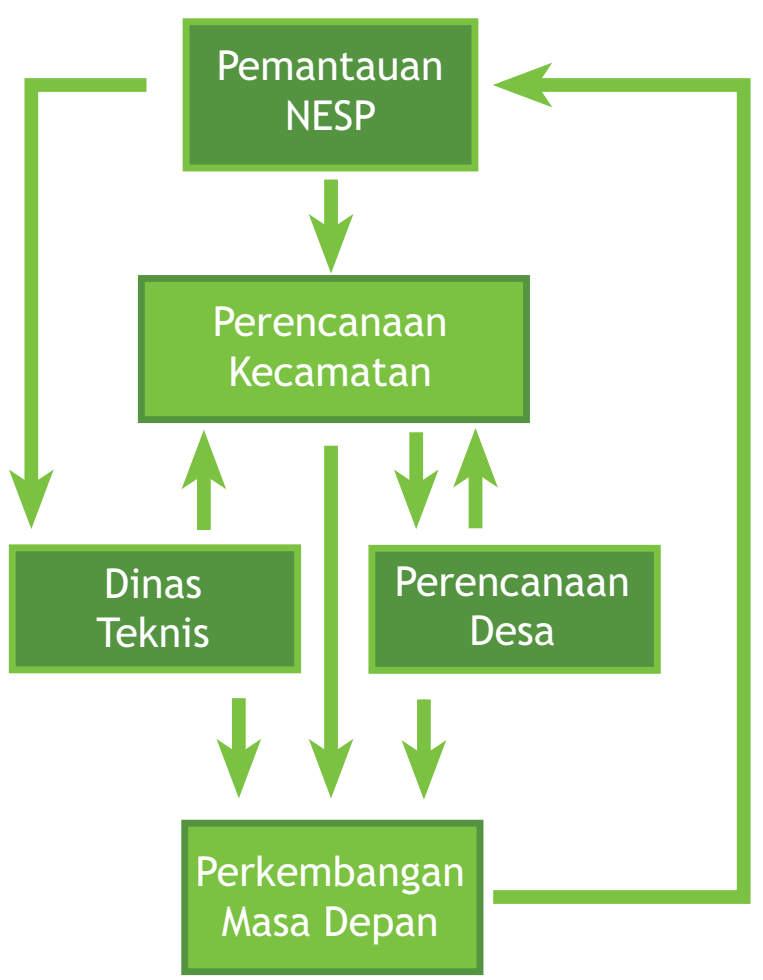

Gambar 16. Siklus pemantauan dan perencanaan di Kutai Barat. 


\section{Kotak 26. Saran untuk mulai}

Mengembangkan suatu sistem pemantauan kemiskinan lebih mudah daripada yang dibayangkan. Badan statistik atau pakar dari universitas dapat membantu menentukan strategi sampling, analisis data dan pelatihan tim. Dalam banyak kasus, kadang sudah cukup untuk memasukkan beberapa indikator ke dalam program pemantauan yang sudah berjalan untuk memperoleh gambaran kemiskinan yang lebih menyeluruh (sebagaimana di NESP).

Cara terbaik untuk memulai:

- Cari informasi tentang program pemantauan kemiskinan yang sudah ada.

- Identifikasi celah dan kekurangan program-program tersebut (misalnya, indikator tidak spesifik untuk daerah setempat, kemiskinan hanya didefinisikan berdasarkan penghasilan atau konsumsi)

- Kembangkan model kemiskinan Anda sendiri (NESP dapat digunakan sebagai titik awal)

- Kembangkan indikator kemiskinan (tambahan) untuk mewujudkan model Anda

- Bahas desain dan logistik sistem pemantauan kemiskinan (baru atau perubahan) dengan badan statistik, akademisi atau lainnya (LSM, proyek) yang bersedia membantu

- Uji sistem pemantauan Anda setidaknya dalam dua uji coba dan sempurnakan sampai temuan Anda mencerminkan situasi kemiskinan yang sesungguhnya terjadi di kawasan Anda

- Lembagakan sistem pemantauan kemiskinan Anda untuk memastikan keberlanjutannya

- Publikasikan temuan Anda dan laporkan kembali ke masyarakat

- Hubungkan program pemantauan itu dengan sistem perencanaan pembangunan di kawasan Anda

- Periksa validitas model kemiskinan Anda setiap 5 tahun-penyebab kemiskinan dapat berubah!

Anda dapat memperoleh uraian lengkap model NESP di:

Gönner, C., Haug, M., Cahyat, A., Wollenberg, L., de Jong,

W., Limberg, G., Cronkleton, P., Moeliono, M. and Becker, M. 2007 Capturing nested spheres of poverty: a model for multidimensional poverty analysis and monitoring. Occasional Paper No. 46. CIFOR, Bogor, Indonesia.

Manual di bawah ini membahas langkah demi langkah pengembangan dan implementasi sistem pemantauan kemiskinan di Kutai Barat:

Cahyat, A., Gönner, C. and Haug, M. 2007 Mengkaji Kemiskinan dan Kesejahteraan Rumah Tangga: Sebuah Panduan dengan Contoh dari Kutai Barat, Indonesia. CIFOR, Bogor, Indonesia. 121p. 
Alat 3:

Mengevaluasi

program

pemerintah

daerah melalui

kelompok fokus

masyarakat

\section{Apakah evaluasi masyarakat itu?}

Evaluasi masyarakat adalah suatu cara yang dapat dilakukan oleh pemerintah daerah untuk mempelajari apakah program memiliki dampak seperti yang diinginkan. Ada banyak cara untuk melakukan evaluasi-alat yang dipilih dalam buku panduan ini membahas tentang wawancara kelompok fokus. Kelompok fokus adalah panel sekelompok orang yang berasal dari warga yang sama, yang melakukan pertemuan untuk mendiskusikan atau mengevaluasi topik khusus dan dipandu oleh seorang fasilitator. Kelompok fokus merupakan sarana yang cepat dan hemat biaya untuk mengumpulkan berbagai pendapat yang diambil dari kelompok tertentu. Untuk tujuan kegiatan ini, anggota kelompok fokus berasal dari masyarakat yang menjadi sasaran program pemerintah yang sedang dievaluasi. Anggota kelompok fokus tersebut harus mengetahui benar program yang dilaksanakan dan apakah program tersebut membuahkan hasil dan dampak yang diharapkan. Oleh karena itu, kelompok fokus dapat memberikan umpan-balik yang berharga bagi pemerintah yang berupaya untuk menjawab tantangan kebutuhan masyarakatnya.

Setelah kegiatan wawancara selesai, hasil dari beberapa kelompok fokus dikumpulkan dan diringkas dalam laporan tertulis. Laporan tertulis ini dapat mencantumkan skor dan grafik yang telah diukur. Informasi ini kemudian dilaporkan kembali kepada pemerintah daerah sebagai masukan untuk siklus perencanaan dan pengambilan keputusan selanjutnya. 
Mengapa evaluasi masyarakat diperlukan?

Masyarakat adalah penerima manfaat dari berbagai program pemerintah. Akan tetapi, program-program tersebut seringkali tidak memenuhi kebutuhan setempat atau tidak meningkatkan kesejahteraan. Pemerintah sering tidak belajar dari masalah tersebut. Saat pemerintah menyadari adanya masalah, mereka terlambat untuk menyesuaikan programprogramnya.

Evaluasi masyarakat merupakan sarana bagi masyarakat untuk menyampaikan pendapatnya dan untuk berkomunikasi dengan pejabat pemerintah. Evaluasi ini juga dapat digunakan untuk memenuhi persyaratan hukum tentang partisipasi masyarakat di dalam proses pengambilan keputusan pemerintah. Selain itu, saat masyarakat bisa menyuarakan pendapatnya tentang program yang dapat berpengaruh pada kehidupannya, pemahaman yang lebih lengkap tentang kemiskinan dan kesejahteraan akan diperoleh.

Evaluasi masyarakat akan menghasilkan:

- Masukan warga ke dalam pengambilan keputusan pemerintah melalui umpan-balik tentang pelaksanaan, hasil, dan dampak program pemerintah daerah;

- Proses yang memberdayakan warga miskin melalui pemahaman yang lebih baik terhadap kerja pemerintah daerah dan apa yang mereka harapkan dari program tersebut;

- Kesempatan bagi pemerintah daerah untuk berkomunikasi tentang programnya dan membangun hubungan dengan anggota masyarakat;

- Transparansi yang lebih baik tentang pelaksanaan dan kualitas program pemerintah.

Jenis evaluasi ini juga dapat membantu pemerintah daerah untuk lebih memusatkan perhatian pada masalah yang paling penting bagi masyarakatnya. Pejabat pemerintah daerah cenderung hanya memantau aspek-aspek pelaksanaan proyek tertentu, seperti pengeluaran biaya dan hasil kegiatan yang bersifat fisik (seperti jumlah pompa air yang dibeli). Hal-hal ini biasanya merupakan persyaratan yang diatur oleh tingkat pemerintahan yang lebih tinggi, terutama untuk tujuan tanggung gugat. Masyarakat biasanya menginginkan dampak

\section{Kotak 27. Diskusi kelompok fokus}

Diskusi kelompok fokus adalah metode yang efisien dan hemat biaya untuk mengetahui berbagai pandangan di masyarakat. Masyarakat dapat berbagi informasi tentang program pemerintah. Kelompok fokus akan menjadi efektif jika peserta dikelompokkan berdasarkan kepentingan atau identitas, misalnya, kelompok perempuan, laki-laki, pemuda, orang tua, tokoh masyarakat, atau berbagai kelompok etnik. Jumlah dan komposisi kelompok fokus harus disesuaikan dengan kondisi lokal. Sebagai acuan, kelompok fokus harus terdiri dari 5-10 orang untuk memudahkan pendampingan dan pencatatan.

Masalah dalam kelompok fokus bisa berupa ánggapan kelompok atau dinamika kelompok yang mempengaruhi pandangan peserta kelompok. Akan tetapi, ada beberapa langkah yang dapat diambil fasilitator untuk mencegah masalah tersebut. Misalnya, pengaruh kepala desa atau elit masyarakat terhadap masyarakat dapat ditekan melalui penggunaan cara pemberian suara yang rahasia untuk evaluasi.

Mengelola kelompok fokus memerlukan keterampilan pendampingan yang kuat. Jika tidak ada fasilitator yang terampil, maka penggunaan metode ini tidak dianjurkan Tetapi, dalam beberapa kasus, merancang kembali proses diskusi yang tidak menuntut tersedianya fasilitator yang handal masih mungkin dilakukan. 


\section{Kotak 28. Belum responsif di Indonesia}

Secara teoritis, desentralisasi membantu pemerintah untuk lebih tanggap terhadap masyarakatnya. Idealnya, masyarakat mempunyai lebih banyak peluang untuk mengajukan permintaan dan memberikan umpan-balik kepada pemerintah daerah karena pengambil keputusan berada di tingkat daerah. Tapi, pada kenyataannya, desentralisasi tidak otomatis membuat pemerintah menjadi lebih tanggap.

Indonesia terbiasa dengan hal yang berdasarkan perintah. Karena 32 tahun kekuasaan otoriter dan pemerintahan terpusat yang dikendalikan oleh Soeharto (1965-1998), pejabat daerah di Indonesia tidak berpengalaman tentang perencanaan bottom-up. Organisasi masyarakat sipil lemah setelah mengalami tekanan, dibubarkan, atau dilarang selama beberapa dekade. Meskipun sejumlah peraturan mencantumkan partisipasi masyarakat setempat, tapi peraturan tersebut jarang dipatuhi. Departemen Dalam Negeri telah mengembangkan panduan tentang perencanaan pembangunan desa partisipatif dan melakukan pelatihan untuk menerapkan metode tersebut, tapi pada tahun 2006 staf Kabupaten masih belum menggunakan metode tersebut.

Ada banyak alasan mengapa pemerintah daerah tidak menjadi lebih tanggap:

- Banyak pejabat tidak menghargai masukan dari masyarakat. Pejabat lebih tertarik mempertahankan status mereka sebagai pejabat pemerintah dan merendahkan masyarakatnya;

- Para pejabat seringkali enggan mengunjungi desa terpencil;

- Perhatian utama daerah adalah tanggung gugat kepada otoritas negara atas anggaran yang diterima; oleh karena itu, pejabat daerah cenderung memusatkan perhatian pada indikator fisik dan finansial yang berkaitan dengan pelaksanaan sebagai ukuran keberhasilan suatu program;

- Daerah jarang mengumpulkan informasi tentang seberapa baik program yang dijalankan; lebih jauh, pengalaman dan keterampilan masyarakat dalam menyampaikan kebutuhannya sangat kurang;

- Terakhir, budaya organisasi yang hirarkis dan peluang kolusi, korupsi, dan pengambilan keputusan untuk keuntungan pribadi membuat pejabat daerah enggan untuk memantau hasil.

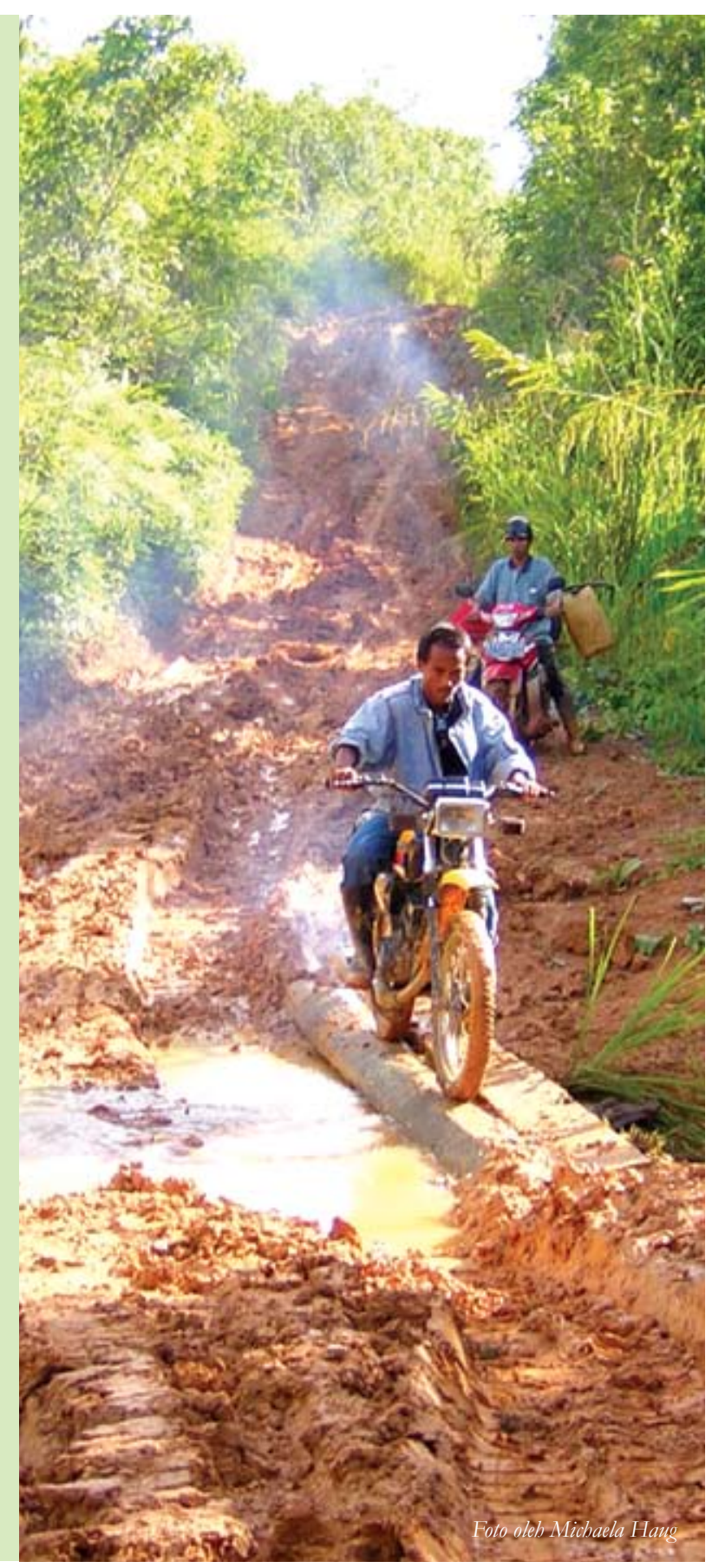


dan manfaat kegiatan yang nyata (misalnya jumlah rumah tangga yang memiliki akses kepada pompa air atau apakah pompa air tersebut berfungsi) daripada hanya pada keluaran fisik program. Pemantauan program yang mandiri dapat menjadi suatu proses pemeriksaan terhadap laporan yang dihasilkan pemerintah. Evaluasi juga dapat menjadi informasi tentang pemborosan atau ketidakefisienan dalam program.

Saat mengorganisasi kelompok fokus, pastikan bahwa manfaat berpartisipasi dalam proses evaluasi sudah jelas. Masyarakat memiliki dorongan untuk berpartisipasi jika informasi yang dihasilkan dari penilaian yang dilakukan masuk ke dalam program pemerintah dan meningkatkan komunikasi dengan pemerintah. Pejabat pemerintah daerah harus terdorong untuk berpartisipasi guna meningkatkan efisiensi dan efektivitas program penanggulangan kemiskinan dan untuk memperoleh dukungan dari masyarakatnya.

\section{Cara melakukan evaluasi masyarakat: Langkah demi langkah}

Alat evaluasi masyarakat terdiri dari delapan langkah, mulai dari menetapkan tujuan evaluasi hingga memperbaiki program pemerintah. Proses pengorganisasian dan penerapan diskusi kelompok fokus dijelaskan satu-per-satu (lihat Gambar 17).
Kotak 29. Waktu dan bahan yang dibutuhkan untuk evaluasi masyarakat

- 2 hari untuk perencanaan

- 2 hari untuk melatih fasilitator

- 2 hari untuk (kelompok) masyarakat tergantung pada kesediaan anggota masyarakat

- 2 hari untuk penyampaian tindak lanjut

- Flipchart, alat tulis, plakban, kartu skor.

\section{Tim dan peserta}

- 2 fasilitator

- 1 pencatat

- Sekitar 10 peserta per kelompok fokus (jumlah kelompok fokus bisa tiga atau lebih, jika kondisi memungkinkan).

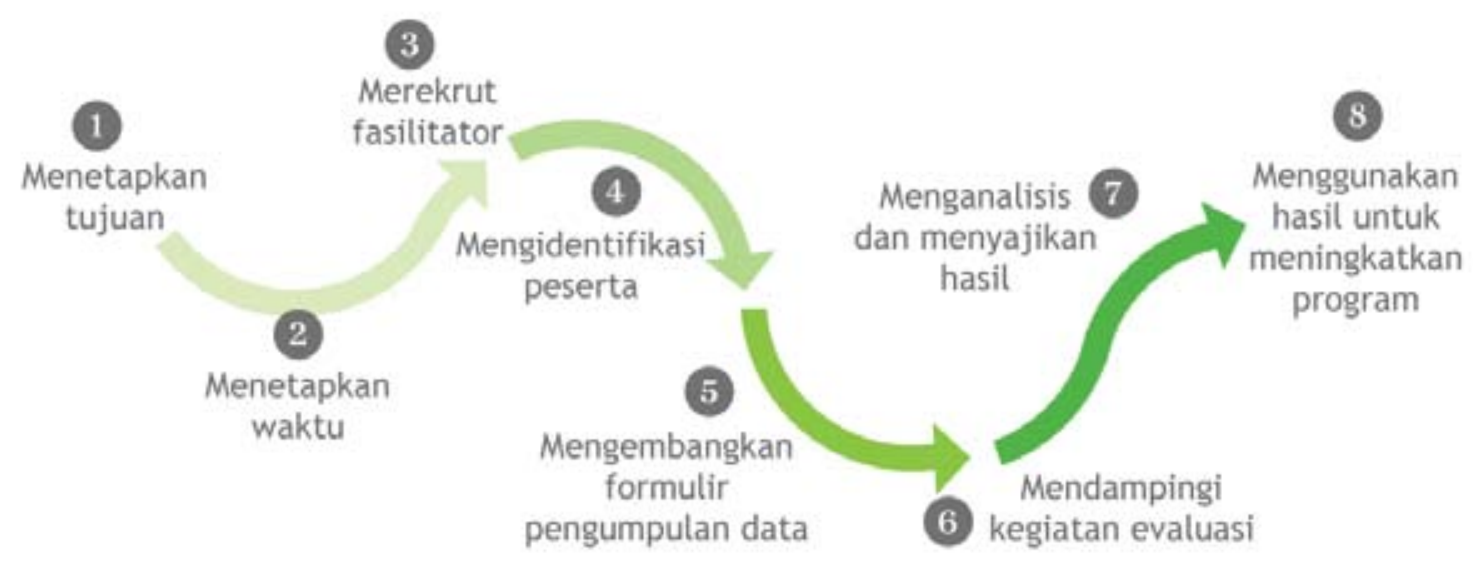

Gambar 17. Proses pengorganisasian dan penerapan diskusi kelompok fokus. 
Kesepakatan tujuan dan harapan evaluasi masyarakat sejak awal merupakan hal yang sangat penting. Adakan pertemuan dengan pejabat pemerintah daerah dan tokoh masyarakat kemudian diskusikan hal berikut ini:

- Apa tujuan dari evaluasi ini? Apakah evaluasi ini untuk meningkatkan pelaksanaan program yang sedang berjalan atau meningkatkan perencanaan proyek mendatang?

- Siapakah penggerak utama evaluasi ini? Apakah pemerintah daerah yang memerlukan umpanbalik pelaksanaan programnya atau masyarakat yang mengeluhkan tentang ketidaksesuaian antara kebutuhan dan bantuan pemerintah?

- Kelompok fokus seperti apa yang layak? Bagaimanakah seharusnya keragaman masyarakat dapat terwakili?

- Siapa yang harus menjadi fasilitator dalam evaluasi? Mengontrak fasilitator terlatih dapat mengurangi konflik kepentingan atau manipulasi para peserta, tapi apakah tersedia biaya tambahan ataukah pihak luar akan kurang mengetahui dinamika setempat?

- Bagaimana laporan evaluasi akan digunakan? Dapatkah laporan dikirimkan langsung kepada pemerintah daerah atau haruskah disebarkan kepada media massa untuk menghindari agar laporan evaluasi tersebut tidak mudah disembunyikan?

- Bagaimana evaluasi akan dihubungkan dengan proses perencanaan pembangunan? Dan bagaimana evaluasi dapat dilembagakan?

Jika diskusi telah selesai, pengurus membuat rumusan singkat tentang tujuan evaluasi, menjelaskan metode dan sasaran kegiatan evaluasi, serta memastikan bahwa badan pemerintah dan masyarakat memahami proses dan hasil yang diharapkan. Rumusan tujuan harus dibagikan kepada para pejabat pemerintah daerah dan masyarakat.

\section{Kotak 30. Perbandingan fasilitator}

\begin{tabular}{|c|c|c|}
\hline Fasilitasi oleh & Kelebihan & Kekurangan \\
\hline Anggota masyarakat & $\begin{array}{l}\text { Memiliki pengalaman langsung tentang } \\
\text { program } \\
\text { Memiliki dorongan langsung untuk terlibat }\end{array}$ & $\begin{array}{l}\text { Mungkin tidak memiliki cukup kemampuan } \\
\text { Mungkin memiliki kepentingan yang dapat } \\
\text { mempengaruhi hasil }\end{array}$ \\
\hline Pejabat pemerintah & $\begin{array}{l}\text { Mengetahui program yang telah } \\
\text { dilaksanakan } \\
\text { Dapat langsung menggunakan hasil untuk } \\
\text { perencanaan } \\
\text { Dapat melaksanakan evaluasi masyarakat } \\
\text { pada skala besar (juga sebagai sistem } \\
\text { pemantauan) }\end{array}$ & $\begin{array}{l}\text { Memiliki pengalaman terbatas untuk } \\
\text { memfasilitasi masyarakat } \\
\text { Tergantung pada kemauan politik (dan } \\
\text { pendanaan) dari pengambil keputusan } \\
\text { pemerintah } \\
\text { Mungkin memiliki kepentingan yang dapat } \\
\text { mempengaruhi hasil }\end{array}$ \\
\hline $\begin{array}{l}\text { LSM atau lembaga } \\
\text { independen lain }\end{array}$ & $\begin{array}{l}\text { Cenderung memiliki fasilitator } \\
\text { berpengalaman } \\
\text { (Idealnya) tidak memiliki kepentingan }\end{array}$ & $\begin{array}{l}\text { Kurang memiliki pengetahuan langsung } \\
\text { tentang program } \\
\text { Perlu dibayar } \\
\text { Diperlukan dana untuk pengulangan } \\
\text { sehingga keberlanjutan tidak terjamin }\end{array}$ \\
\hline
\end{tabular}


Pengaturan waktu perlu disesuaikan dengan siklus perencanaan tahunan pemerintah daerah. Koordinasi pengaturan waktu dengan pemerintah daerah dilakukan untuk memastikan bahwa laporan evaluasi dapat dijadikan umpanbalik ke dalam proses perencanaan yang resmi. Evaluasi juga harus mendahulukan perencanaan tahunan desa (lihat Alat 4), agar pembelajaran yang diperoleh dari tahun sebelumnya dapat dimasukkan ke dalam rencana pembangunan yang baru.

Langkah 3. Merekrut fasilitator

Identifikasi organisasi atau individu yang tertarik dan tepat untuk melaksanakan evaluasi dan memfasilitasi kegiatan. Para fasilitator harus berpengalaman dalam melaksanakan berbagai pertemuan, mendorong kegiatan diskusi, dan menyeimbangkan berbagai pendapat. Fasilitator bisa berasal dari masyarakat, pemerintah daerah, atau dari organisasi independen. Pemilihan fasilitator yang berasal dari berbagai kelompok ini sangat dianjurkan. Namun demikian, perlu adanya konsistensi untuk dapat melacak perubahan yang terjadi. Putuskan dengan hatihati-fasilitator tidak boleh memiliki kepentingan pribadi dalam hasil evaluasi.

- Anggota masyarakat dapat menjadi fasilitator jika mereka cukup berpengalaman. Tetapi, terdapat kelemahan dalam penggunaan fasilitator dari masyarakat, karena mereka mungkin memiliki kepentingan dan mencoba untuk mempengaruhi proses secara tidak seimbang. Selain itu, beberapa kelompok masyarakat tidak memiliki kapasitas untuk melaksanakan evaluasi sendiri.

- Pejabat pemerintah daerah mungkin bisa menjadi fasilitator yang baik jika ada dukungan politik dari pemerintah untuk proses ini. Dengan keterlibatan pejabat pemerintah, evaluasi dapat diulangi di banyak lokasi, dan evaluasi dapat diulang setiap tahunnya. Hasil dari evaluasi masyarakat yang diarahkan oleh pemerintah daerah dapat langsung dimasukkan ke dalam proses

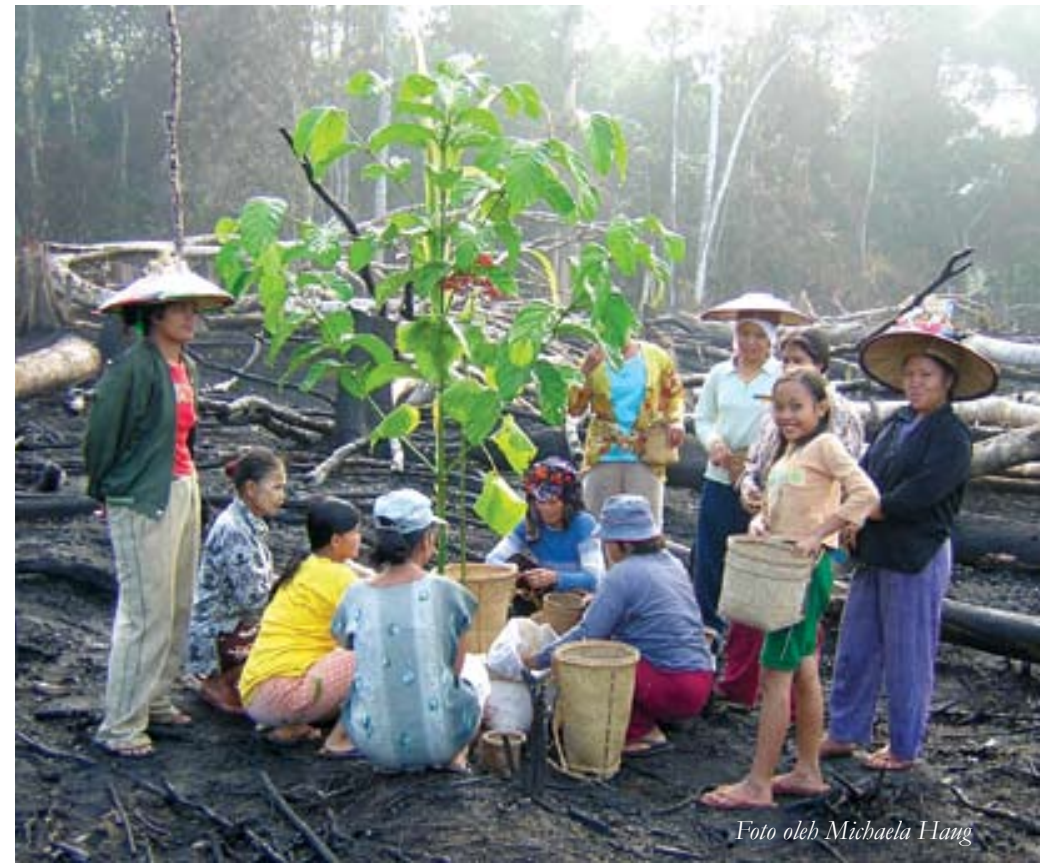

Mengindentifikasi peserta yang paling memahami tentang pelaksanaan dan dampak suatu program perencanaan pemerintah. Namun demikian, pejabat pemerintah dapat mempengaruhi apa yang akan dikatakan masyarakat dalam pertemuan. Anggota masyarakat mungkin merasa segan saat menyampaikan pandangan negatif atau kritis tentang program kerja pemerintah.

Untuk evaluasi yang lebih obyektif, libatkan LSM, universitas atau organisasi independen lainnya. Organisasi tersebut biasanya memiliki fasilitator yang cakap. Namun, keterlibatannya dapat menyebabkan munculnya 
Kotak 31. Contoh formulir yang digunakan untuk evaluasi masyarakat tentang program pembangunan di Malinau

\begin{tabular}{l|l|l|l|l|l}
\hline Sektor & $\begin{array}{l}\text { Proyek atau } \\
\text { program }\end{array}$ & $\begin{array}{l}\text { Sumber } \\
\text { (daerah, } \\
\text { pemerintah } \\
\text { pusat) }\end{array}$ & $\begin{array}{l}\text { Evaluasi } \\
\text { implementasi }\end{array}$ & Evaluasi dampak & Keterangan \\
\hline Pendidikan & & & & & \\
\hline Kesehatan & & & & & \\
\hline
\end{tabular}

biaya tambahan. Karena evaluasi ini harus dilaksanakan setiap tahun, biaya untuk organisasi independen yang

melakukan evaluasi harus dianggarkan setiap tahun.

Kotak 30 adalah ringkasan perbandingan kelebihan dan kekurangan pendampingan kelompok fokus oleh fasilitator yang berbeda.

\section{Langkah 4. Mengidentifikasi dan memilih peserta}

Di setiap masyarakat pasti terdapat orang-orang yang sangat mengenal pelaksanaan dan dampak program. Sifat program akan menentukan siapa yang harus disertakan dalam evaluasi. Contohnya, orang tua dapat memberikan informasi tentang program pendidikan, sedangkan pemuda dapat mengetahui tentang fasilitas olah raga yang dibangun akhirakhir ini. Beberapa proyek memiliki dampak pada setiap orang. Pada kasus tersebut, mintalah beragam wakil masyarakat untuk berpartisipasi dalam proses evaluasi.

Cobalah untuk mendapatkan perwakilan dari semua kelompok di dalam masyarakat. Peserta yang lebih lemah atau terpinggirkan dapat membentuk kelompok terpisah sehingga mereka dapat merasa lebih berani untuk menyuarakan pendapatnya.

\section{Langkah 5. Mengembangkan formulir pengumpulan data}

Membuat formulir sederhana untuk mengumpulkan data. Formulir ini akan mengarahkan diskusi dan pengumpulan data pada masalah yang paling penting dan akan memudahkan pengumpulan hasil (Lihat Kotak 31 untuk contoh).

\section{Langkah 6. Mendampingi kegiatan evaluasi}

Langkah-langkah di bawah ini menjelaskan tentang cara mendampingi evaluasi dengan menggunakan diskusi kelompok fokus.

- Buatlah daftar program yang akan dievaluasi. Tulislah daftar program yang seharusnya sudah dilaksanakan di masyarakat. Identifikasi pihak (instansi) yang bertanggung jawab untuk setiap program. Sumber informasi tambahan dapat menyertakan alokasi anggaran dan laporan tahunan pemerintah, wawancara dengan pejabat pemerintah, dan wawancara dengan tokoh masyarakat. 


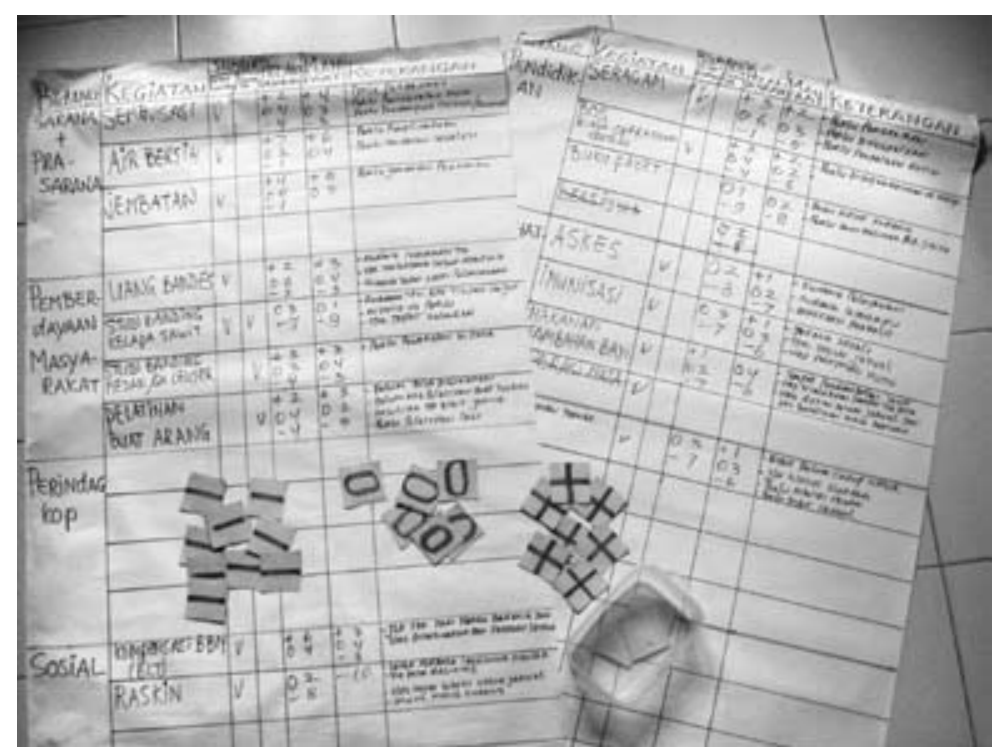

Gambar 18. Contoh kartu untuk pungut suara voting yang digunakan di Malinau selama evaluasi.

- Identifikasi hasil dan dampak yang diharapkan dari setiap program. Diskusikan harapan dari setiap program:

- Apa yang harus dilakukan program?

- Siapa yang harus membantu?

- Berapa banyak individu atau masyarakat yang harus diuntungkan?

- Berapa lama program tersebut dijalankan?

- Catat diskusi ini dalam kolom "Keterangan" pada formulir.

- Jika program digerakkan secara nasional, bandingkan hasil yang diharapkan seperti yang dilaporkan di dalam dokumen pemerintah pusat dengan hasil yang diharapkan masyarakat, hal ini dilakukan untuk mengamati dan memahami bagaimana dan mengapa keduanya berbeda.

\section{Kotak 32. Saran dan pilihan}

- Berikan informasi yang akurat

- Pastikan anonimitas

- Gunakan metode yang menarik, inovatif dan tidak banyak memakan waktu

- Berikan dorongan kepada anggota kelompok untuk berpartisipasi dalam penilaian.

- Diskusikan pelaksanaan dan dampak nyata dari setiap program:

- Siapa yang berpartisipasi?

- Bagaimana keputusan diambil?

- Bagaimana anggaran digunakan?

- Apakah spesifikasi teknis (jika diketahui) dipenuhi?

- Siapa yang diuntungkan dari program ini?

- Bagaimana pelaksanaan program dapat menjadi lebih baik?

- Bagaimana suatu program dapat memberikan hasil yang lebih baik?

- Bagaimana pelaporan seharusnya dilakukan?

- Buat catatan tentang diskusi ini dalam kolom "Keterangan" pada formulir.

- Lakukan pungut suara tentang pelaksanaan dan dampak dari setiap proyek. Mintalah peserta untuk memberi nilai bagi pelaksanaan dan dampak dari setiap proyek atau program. Proses ini harus dilakukan secara anonim agar diperoleh pendapat yang jujur. Salah satu pendekatan adalah dengan menggunakan kartu (lihat Gambar 18). Mintalah peserta mencatat 


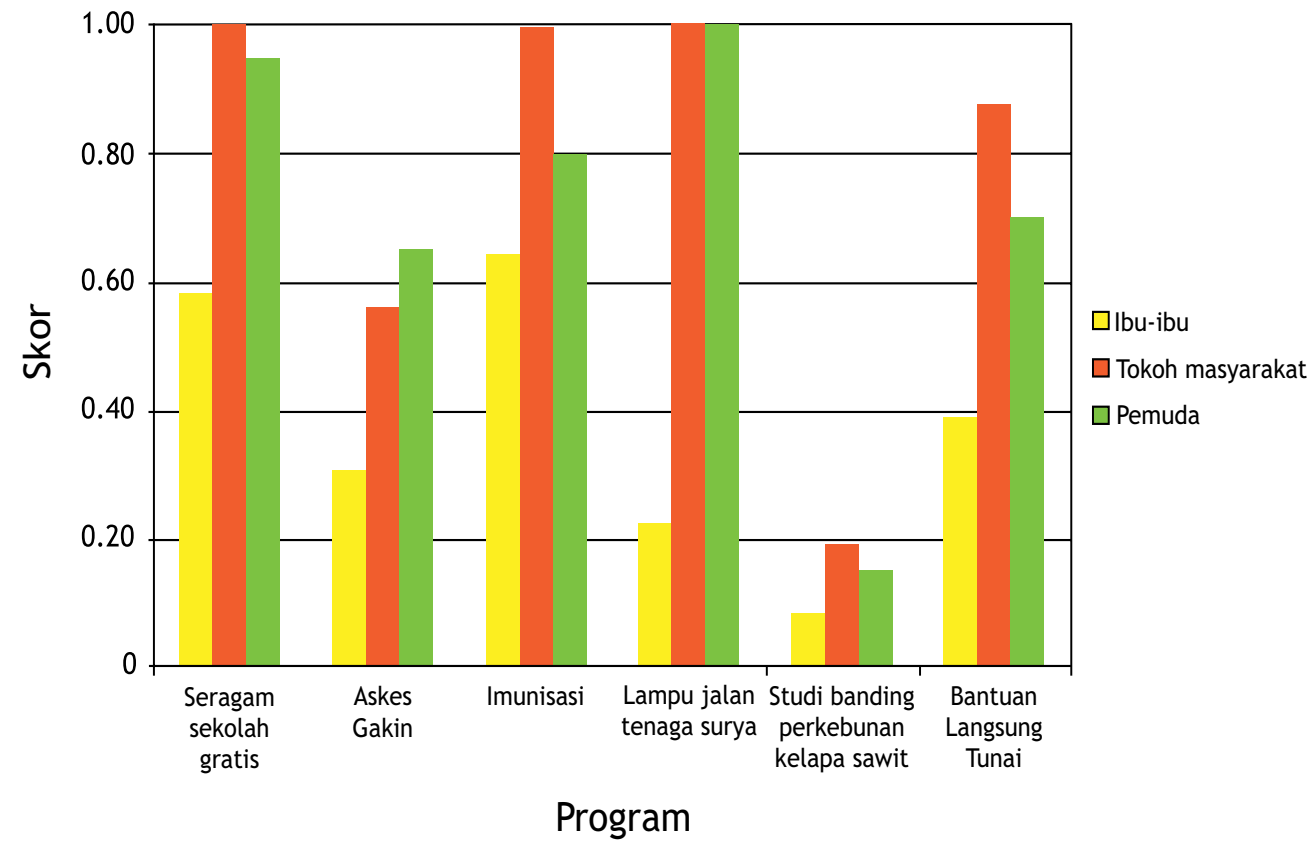

Gambar 19. Perbandingan nilai evaluasi kelompok fokus (yang dinormalisasi) di satu desa di Malinau.

evaluasi mereka pada kertas, misalnya + (implementasi atau dampak positif atau baik), 0 (netral) dan

- (negatif atau buruk). Ingatkan kepada peserta bahwa memberi nilai menurut pendapat mereka masingmasing merupakan hal yang sangat penting.

\section{Langkah 7. Menganalisa dan menyajikan hasil}

Gabungkan hasil menurut program, masyarakat, atau kelompok fokus. Hitung rata-ratanya dan bandingkan hasilnya. Contoh, pejabat mungkin ingin membandingkan kesuksesan program secara keseluruhan yang dilaksanakan di beberapa kelompok masyarakat dengan membandingkan jumlah perempuan dan laki-laki di semua lokasi. Untuk melakukan ini, pertama jumlahkan skor semua perempuan yang berpartisipasi dalam evaluasi. Kemudian bagi total nilai dengan total jumlah peserta. Pembagian ini menghasilkan rata-rata. Ulangi langkah yang sama untuk peserta laki-laki. Prosedur ini memungkinkan diperolehnya perbandingan program antar kelompok dengan jumlah responden berbeda.

Gunakan kode warna untuk menunjukan perbedaan (lihat Gambar 19). Informasi ini berguna bagi pengambil keputusan dengan dampak di lokasi tertentu atau kelompok sasaran.

Atur pemaparan evaluasi untuk anggota masyarakat dan pejabat pemerintah. Sajikan informasi dalam format yang mudah dipahami dan memiliki makna bagi anggota masyarakat dan bagi pejabat pemerintah. Catat komentar dan pendapat yang diberikan selama pemaparan. Catatan ini sangat penting karena hal ini merupakan informasi tentang peningkatan yang 
Kotak 33. Contoh skor dari kelompok fokus†

\begin{tabular}{|c|c|c|c|c|c|c|c|}
\hline \multirow{2}{*}{ Sektor } & \multirow{2}{*}{ Proyek } & \multicolumn{3}{|c|}{ Masyarakat A } & \multicolumn{3}{|c|}{ Masyarakat B } \\
\hline & & Tokoh & Perempuan & Pemuda & Tokoh & Perempuan & Pemuda \\
\hline \multirow[t]{4}{*}{ Pendidikan } & $\begin{array}{l}\text { Seragam sekolah } \\
\text { gratis }\end{array}$ & 0,94 & 0,75 & 0,92 & 1,00 & 0,58 & 0,95 \\
\hline & $\begin{array}{l}\text { Bantuan operasional } \\
\text { sekolah }\end{array}$ & $\neq$ & - & 0,15 & 0,25 & 0,47 & 0,60 \\
\hline & Buku gratis & 0,22 & 0,14 & 0,88 & 0,94 & 0,28 & 0,80 \\
\hline & Beasiswa & N/AS & N/A & $\mathrm{N} / \mathrm{A}$ & 0,81 & 0,47 & 0,50 \\
\hline \multirow[t]{3}{*}{ Kesehatan } & Asuransi kesehatan & 0,72 & 0,29 & 0,69 & 0,56 & 0,31 & 0,65 \\
\hline & Imunisasi & 1,00 & 1,00 & 0,92 & 1,00 & 0,64 & 0,80 \\
\hline & $\begin{array}{l}\text { Makanan tambahan } \\
\text { untuk anak-anak < } 5 \\
\text { tahun }\end{array}$ & 0,72 & 0,93 & 0,73 & 1,00 & 0,14 & 0,85 \\
\hline
\end{tabular}

† Skor dari dua masyarakat tentang dampak beberapa program pendidikan dan kesehatan. Rentang skor dari 0 (dampak sangat negatif) hingga 1 (dampak sangat positif atau baik).

‡ Dalam diskusi dengan tokoh masyarakat, proyek ini tidak disebutkan, jadi tidak ada skor yang diberikan.

$\S \mathrm{N} / \mathrm{A}$, tidak berlaku.

diperlukan. Beberapa keterangan mungkin sangat spesifik, tapi pola yang konsisten akan muncul. Misalnya, di Malinau, ada dua masalah umum yang berhubungan dengan program pemerintah, yaitu kekurangan informasi tentang program tersebut dan kurangnya tindak lanjut, seperti menyediakan bibit tanaman atau pengembangan ternak tanpa bimbingan teknis (Kotak 34 memberi contoh keterangan yang diberikan oleh peserta selama diskusi).

Perlu kehati-hatian dalam mengartikan hasil agar tidak terjadi salah arti. Contohnya, persentase bisa menyesatkan jika hanya beberapa orang dilibatkan dalam suatu kelompok fokus. Misalnya, jika $100 \%$ orang setuju pada evaluasi positif, tapi hanya ada dua orang dalam grup, maka skor persentase tinggi ini memiliki nilai signifikan yang kecil.

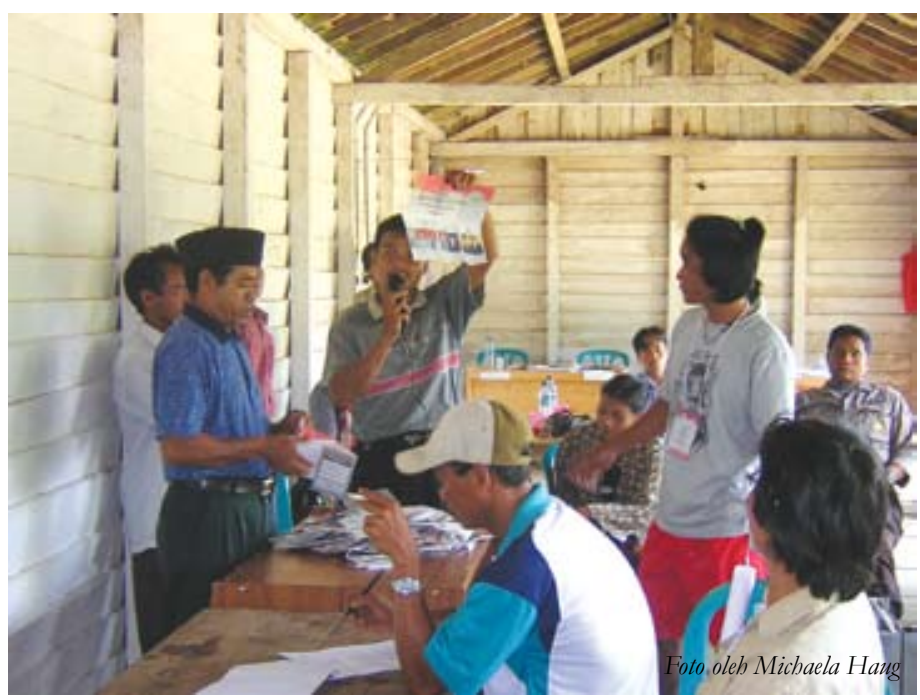

buku panduan untuk pemerintah daerah | 79 


\section{Langkah 8. Menggunakan hasil untuk meningkatkan program}

Hasil dari evaluasi harus disalurkan ke dalam evaluasi dan siklus perencanaan pemerintah. Secara teoritis, sejumlah instansi seharusnya berkepentingan dengan informasi ini. Seperti misalnya dinas yang bertanggung jawab mengevaluasi proyek, badan perencanaan, badan yang bertanggung jawab atas keuangan, dan DPRD. Sebagai alternatif, masyarakat dan organisasi non-pemerintah dapat menggunakan hasil tersebut untuk mengingatkan tentang adanya kekurangan dalam program atau mendorong agar ada perubahan. Kemungkinan akan ada tanggapan akan lebih tinggi apabila ada tekanan dari luar dan dalam lembaga pemerintah.

Hasil evaluasi sangat penting untuk dikomunikasikan pada masyarakat luas, termasuk anggota masyarakat, pemerintah daerah dan lembaga daerah lainnya. Strategi komunikasi dapat meliputi tindakan-tindakan berikut ini:
- Sebarkan hasil kepada peserta dan anggota masyarakat lain; pasanglah hasil di tempat umum agar setiap orang dapat melihat dan mendiskusikannya;

- Atur pertemuan masyarakat untuk menyajikan hasil; mintalah masyarakat untuk melakukan curah pendapat tentang bagaimana mereka akan menggunakan hasil tersebut;

- Fasilitasikan diskusi tentang hasil sebagai bagian dari program tahunan masyarakat (lihat Alat 4);

- Atur pemaparan sehingga anggota masyarakat dapat berbagi hasil mereka dengan pemerintah daerah dan masyarakat lain; undang pihak luar seperti pemerintah daerah, serta organisasi lingkungan dan pembangunan masyarakat;

- Libatkan pers setempat, sampaikan bahan tertulis kepada mereka; sarankan para peserta agar membicarakan tentang pelaksanaan evaluasi dalam acara radio. 
Kotak 34. Contoh keterangan yang diberikan di dalam evaluasi masyarakat terhadap program pembangunan di Malinau

\section{PENDIDIKAN}

- Seragam sekolah gratis:

- Jumlah seragam tidak cukup

- Ukuran beberapa seragam tidak sesuai

- Dana operasional sekolah:

- Informasi tentang program tidak jelas

- Tidak ada pengawasan dalam pelaksanaan

- Tidak sesuai untuk kondisi setempat (harga di Malinau relatif tinggi)

- Buku sekolah gratis:

- Jumlah tidak mencukupi dan tidak semua buku disediakan

- Beasiswa:

- Informasi tentang program tidak jelas

- Jumlah yang disediakan tidak mempertimbangkan perbedaan biaya di tingkat pendidikan yang berbeda

- Tidak ada kendali dalam pelaksanaan

- Beasiswa dari pemerintah daerah belum diterima.

\section{KESEHATAN}

- Asuransi kesehatan:

- Tidak semua orang menerima kartu asuransi kesehatan (persyaratan tidak jelas)

- Pelayanan di pusat kesehatan tidak memuaskan

- Prosedur untuk menggunakan asuransi terlalu birokratis

- Imunisasi:

- Jadwal pelaksanaan tidak menentu

- Beberapa anak mengalami infeksi karena vaksinasi

- Tidak ada layanan medis umum tambahan yang disediakan staf kesehatan selama kunjungan imunisasi.

- Makanan tambahan untuk balita

- Jumlah tidak cukup dan pengiriman tidak menentu. 
Kotak 35. Saran untuk memulai evaluasi masyarakat

Diskusi kelompok fokus untuk mengevaluasi program pemerintah adalah cara yang baik untuk meningkatkan komunikasi antara pemerintah daerah dan masyarakat, tapi mungkin dapat dianggap hal yang peka (untuk dikomunikasikan) atau bahkan mengancam. Dengan demikian, pendekatan awal adalah hal yang penting untuk mencegah kesalahpahaman. Untuk mendapatkan hasil terbaik dengan pendekatan ini, perhatikan hal berikut ini untuk memulai.

- Adakan diskusi atau pertemuan informal dengan pemerintah daerah dan organisasi setempat untuk menyajikan konsep. Diskusi harus meliputi: Apa tujuan evaluasi, dampak sektor mana yang menarik/ relevan, pihak utama mana saja yang terlibat.

Diskusikan hal tersebut dengan pengambil keputusan utama untuk memastikan pemahaman, dukungan dan keterlibatan yang baik. Selama tahap ini, formulir dapat dibuat untuk memudahkan dokumentasi (dan pelaporan) hasil.

- Latih staf yang akan melakukan diskusi kelompok fokus. Pelatihan dapat dilakukan dengan mengadakan pelatihan dengan semua anggota tim survei. Jika waktu yang ada terbatas, latihan di lapangan dapat dilakukan dengan melibatkan anggota tim secara bertahap dalam pendampingan diskusi kelompok fokus.

- Lakukan persiapan saat menuju ke lapangan. Jika pejabat pemerintah akan melakukan diskusi kelompok fokus, penjadwalan dan pendanaan mungkin memerlukan waktu yang agak panjang. Pelaksanaan survei harus mempertimbangkan waktu yang terbaik untuk masyarakat yang akan dikunjungi serta waktu bagi pejabat pemerintah untuk menangani persyaratan birokratis dan mendapatkan anggaran.
Selama tahap ini, masyarakat harus diberitahu (melalui surat atau sarana lain yang layak). Informasi harus mencantumkan tujuan survei dan menjelaskan manfaat kelompok fokus.

Untuk informasi lebih lanjut tentang kelompok fokus dan evaluasi berbasis masyarakat, baca:

Kreuger, R.A. 1988 Focus groups: a practical guide for applied research. Sage, London.

Morgan, D.L. 1997 Focus groups as qualitative research (2nd Edn). Sage, London.

Morgan, D.L. and Kreuger, R.A. 1993 When to use focus groups and why. In: Morgan D.L. (ed.) Successful focus groups. Sage, London.

Stewart, D.W. and Shamdasani, P.N. 1990. Focus groups: theory and practice. Sage, Newbury Park, CA, USA.

Wollenberg, E., Limberg, G., Iwan, R., Rahmawati, R. and Moeliono, M. 2006 Our forest, our decision. A survey of principles for local decision-making in Malinau. CIFOR, Bogor, Indonesia.

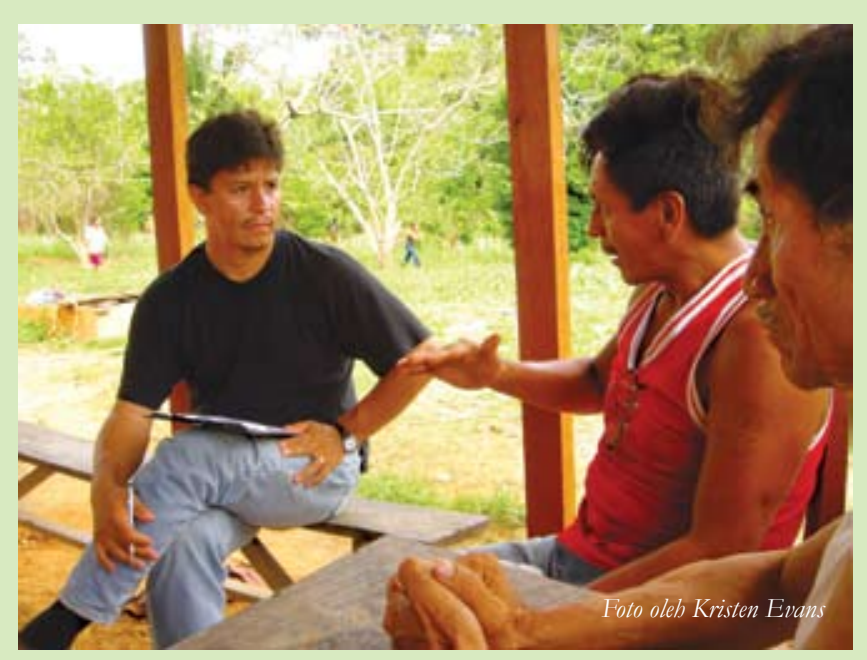


Alat 4:

Menyampaikan

kebutuhan

masyarakat

melalui

\section{perencanaan \\ berbasis skenario}

\section{Apakah perencanaan berbasis skenario itu?}

Skenario adalah gambaran masa depan yang diinginkan. Skenario berguna untuk menggali dan menyampaikan harapan tentang masa depan. Perencanaan berbasis skenario dapat membantu pengembangan visi, pengembangan rencana untuk memenuhi visi tersebut, dan penyampaian rencana kepada pihak lain, termasuk pemerintah daerah.

\section{Mengapa perencanaan berbasis skenario perlu?}

Perencanaan berbasis skenario dapat membantu pemerintah memahami kebutuhan masyarakat. Skenario membantu masyarakat untuk:

- Menetapkan harapan, tujuan, dan keinginan tentang masa depan secara lebih jelas dan terinci;

- Mengidentifikasi perbedaan, asumsi yang tidak realistis, dan kepentingan bersama di antara para peserta;

- Mencapai kata sepakat tentang agenda bersama, yaitu tujuan yang harus dicapai, prioritas, atau bahaya atau kendala yang harus diwaspadai;

- Mengembangkan rencana yang diuraikan menjadi beberapa langkah dengan mendefinisikan bagaimana dan kapan masing-masing langkah tersebut akan dilakukan dan siapa yang bertugas melaksanakannya;

- Mengembangkan keterampilan dalam melakukan perencanaan kolaboratif; 
- Menciptakan rasa memiliki dan tangung jawab untuk melaksanakan program;

- Mendokumentasikan perubahan dalam visi masyarakat.

Pengambil keputusan di pemerintah daerah perlu memahami dengan jelas kebutuhan dan harapan masyarakat agar tanggap terhadap masalah kemiskinan. Pemahaman bisa dicapai dengan meminta masyarakat untuk menyampaikan kebutuhan mereka secara lebih baik kepada pemerintah daerah.

Komunikasi sering kurang efektif karena kurangnya keterlibatan penduduk dalam pemerintahan dan banyaknya kendala dalam komunikasi karena jarak, biaya, atau buruknya sarana dan prasarana. Biasanya, masyarakat kurang sarana dan pengalaman dalam membuat usulan yang dapat mewakili kepentingan seluruh kelompok mereka. Masyarakat kadang-kadang kekurangan informasi atau salah mengerti tentang perannya dalam perencanaan pemerintah, dan mungkin akan bereaksi secara kontra-produktif atau bahkan tidak bertindak sama sekali. Karena kelemahan inilah, saat masyarakat berkomunikasi dengan pejabat pemerintah, masukan mereka tanpa sengaja dapat:

- Mengesankan adanya kepentingan pribadi yang sempit pada beberapa individu saja;

- Tidak melibatkan sebagian stakeholder, terutama golongan minoritas, dan rakyat miskin.
Kotak 36. Di Bolivia: Masalah dengan proses perencanaan kota

Di Bolivia, perwakilan dari pemerintah daerah mengeluhkan masyarakat pedesaan yang tidak berpartisipasi secara aktif dalam perencanaan kota atau paham sepenuhnya tentang prosesnya. Pada rapat perencanaan kota, pimpinan masyarakat yang dipilih sering tidak hadir atau sering datang tanpa persiapan atau membawa usulan yang tidak sesuai dengan usulan masyarakat. Karena sebagian besar penduduk tidak tertarik, otoritas kota merasa kerja mereka tidak diakui dan hampir tidak mungkin untuk memenuhi harapan perubahan dari anggota masyarakat. Di lain pihak, anggota masyarakat beralasan bahwa mereka jarang mengadakan rapat dan tidak tahu cara mengatasi keapatisan dan konflik internal untuk membuat usulan bersama. Selain itu, mereka beralasan bahwa mereka kesulitan dalam mempersiapkan pertemuan perencanaan kota karena mereka jarang mendapatkan pemberitahuan pemerintah sebelumnya dan penjadwalan yang membingungkan. Masyarakat sering tidak menghargai proyek kota karena proyek kota tidak memperhatikan prioritas mereka.

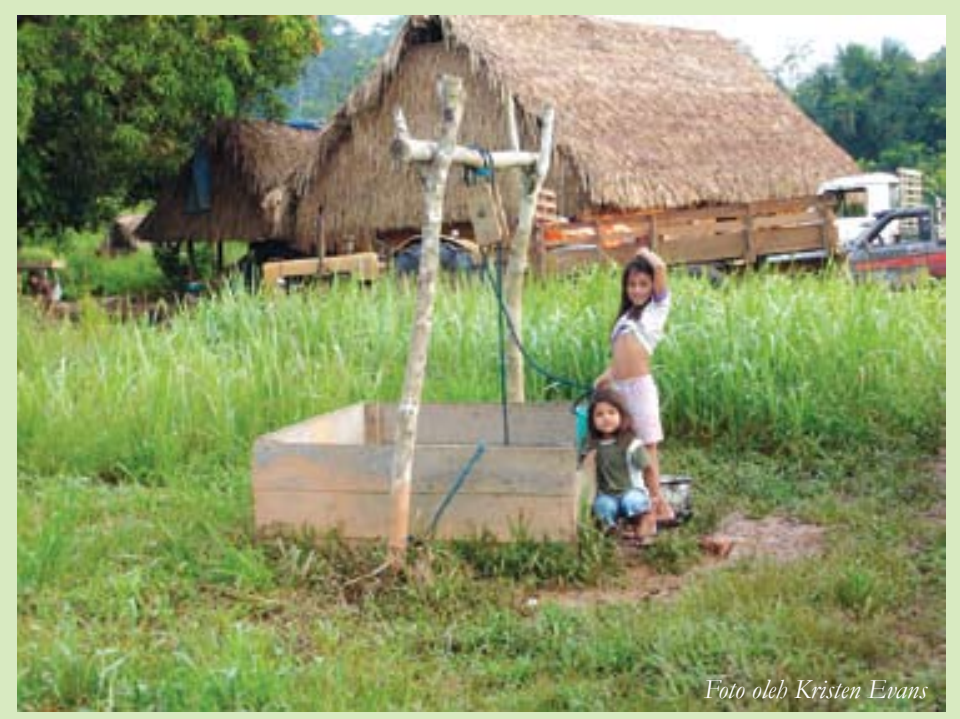

Proyek-proyek kota yang ditinggalkan, seperti sumur yang tidak selesai ini, seringkali terjadi karena kurangnya komunikasi yang baik antara masyarakat dan pemerintah daerah. 
- Dokumentasi yang penting untuk transparansi dan akuntabilitas kurang;

- Jauh dari pemikiran jangka panjang atau strategis.

Perencanaan berbasis skenario dapat mengatasi masalah tersebut dengan memberdayakan kelompok masyarakat untuk bersama-sama mendefinisikan usulan mereka dan menyajikannya untuk perencanaan pemerintah daerah.

\section{Cara menggunakan skenario perencanaan: Langkah demi langkah}

Alat ini terdiri dari dua metode, yaitu: mengidentifikasi visi masyarakat, disebut Pembentukan Visi, dan mengembangkan jalur atau rencana untuk mencapai visi tersebut, disebut Jalur.
Kotak 37. Waktu dan materi yang dibutuhkan dalam pembentukan visi

- 2 hari untuk perencanaan dan melakukan ramah-tamah dengan masyarakat

- 3-4 jam untuk lokakarya

- 1 hari untuk mempersiapkan dan menyajikan hasil dan tindak lanjut

- Papan tulis, flipchart, alat tulis, pita pembatas.

Tim dan peserta

- 2 fasilitator (bisa dari pejabat daerah atau profesional)

- 2 pencatat (bisa dari pihak desa)

- 15-25 peserta dewasa.

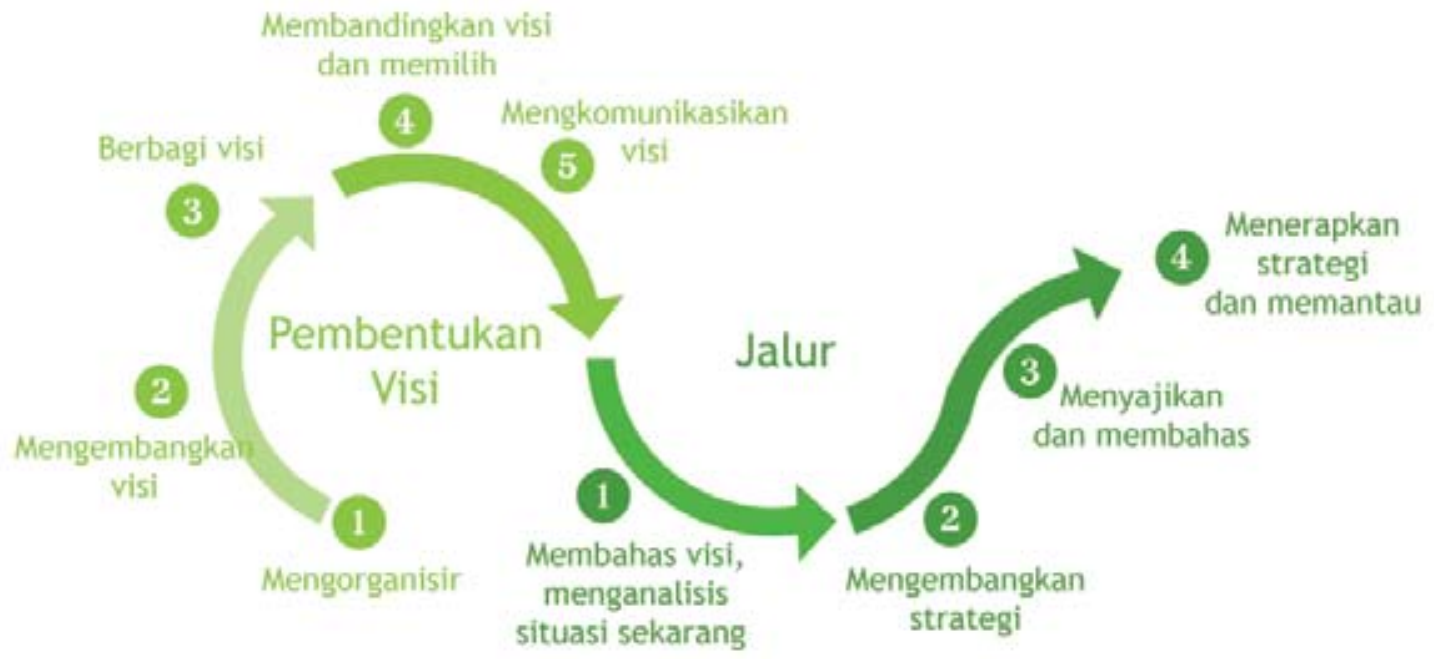

Gambar 20. Urutan metode dalam perencanaan berbasis skenario. 
Metode tersebut dapat digunakan secara terpisah atau bersama. Jika keduanya digunakan, Pembentukan visi biasanya muncul terlebih dahulu, lalu diikuti dengan jalur.

\section{Pembentukan Visi}

Pembentukan visi adalah teknik untuk membantu peserta membayangkan masa depan yang ideal untuk warga mereka. Metode ini pada dasarnya adalah proses dalam menetapkan tujuan. Metode ini menciptakan ruang pribadi yang memungkinkan adanya perenungan sehingga masyarakat merasa bebas untuk mengekspresikan harapan mereka dan menyampaikan mimpi mereka tentang masa depan. Anggota masyarakat kemudian menyampaikan visi mereka dan mencapai kesepakatan tentang prioritas dan tujuan bagi masyarakat. Tujuan ini menjadi titik awal bagi rencana tindakan demi pembangunan masyarakat.

Pembentukan visi menghasilkan gambaran masa depan milik bersama dalam bentuk dokumen tertulis atau gambar, seperti gambar sketsa. Dokumentasi tidak hanya membantu anggota kelompok menganalisa keragaman visi mereka, tapi juga menghasilkan catatan untuk peserta yang dapat dipertanggungjawabkan.

\section{Langkah 1. Mengorganisasi dan mengarahkan}

Fasilitator yang tidak begitu mengenal suatu kelompok masyarakat harus merencanakan waktu bersama masyarakat tersebut sebelum memulai lokakarya. Perencanaan waktu ini memberikan kesempatan bagi fasilitator untuk membicarakan masalah dan kekhawatiran yang dihadapi berbagai keluarga dan untuk mempelajari tentang aktivitas keseharian masyarakat. Fasilitator harus mencoba untuk melibatkan sebanyak mungkin anggota masyarakat-terutama mereka yang nampak lebih tersisih-dalam pembicaraan informal atau percakapan tentang kehidupan mereka dan masyarakat.

Pertanyaan diskusi meliputi:

- Bagaimana kondisi masyarakat Anda?

- Bagaimana kondisi keluarga?

- Seperti apa kondisi tanah dan hutan di sini?

- Apa yang dilakukan masyarakat untuk menyambung hidup?

- Mengapa beberapa orang berada dalam kondisi sejahtera atau miskin?

Peta atau foto tentang masyarakat dapat mendorong dilakukannya perenungan. Meluangkan waktu dengan masyarakat sebelum bertindak juga mendorong partisipasi dengan memberi kesempatan untuk mengundang anggota masyarakat secara langsung untuk menghadiri lokakarya.

\section{Langkah 2. Mengembangkan visi}

Langkah terpenting dalam pelaksanaan pembentukan visi adalah membantu peserta menghilangkan kekhawatiran saat ini, memusatkan perhatian pada kegiatan, dan menggunakan imajinasi mereka untuk berpikir secara kreatif tentang masa depan yang ideal. Mungkin terdengar mudah, tapi langkah ini cukup menantang. Jika tidak difasilitasi dengan cermat, pembentukan visi tidak akan menghasilkan pemahaman atau analisis yang berguna nantinya.

Pertama, ajak peserta dan buat suasana santai sehingga orang-orang merasa nyaman membayangkan kemungkinan hasil masa depan.

Berikutnya, pilih waktu tertentu dari masa depan untuk dibayangkan. Waktu ini boleh berbeda bergantung pada kebutuhan fasilitator, tapi lebih baik bila memilih waktu yang jauh di masa depan yang dapat melepaskan peserta dari masalah atau kondisi sekarang yang dapat menghambat pilihan yang mereka pertimbangkan. Fasilitator harus mengarahkan proses dengan menyeimbangkan pertanyaan terbuka yang 
akan mendorong imajinasi dengan arahan pertanyaan yang lebih spesifik untuk memastikan bahwa masalah utama (bagaimanapun cara menjelaskannya) dipertimbangkan oleh masing-masing peserta.

Mintalah peserta untuk santai, menutup mata, dan mengosongkan pikirannya. Mulailah mengajak mereka membayangkan perjalanan ke masa depan. Berikut adalah contoh naskah untuk memulai:

Kita akan melakukan perjalanan 20 tahun ke masa depan, jadi pertama kita harus mempercepat waktu dulu. Saat saya menghitung sampai hitungan ke 20, Anda akan semakin tua. Anak Anda tumbuh dewasa, masyarakat berubah, dan semakin membaik. Kehidupan menjadi lebih baik, semua orang lebih bahagia. Berbagai masalah telah diselesaikan. Saat Anda membuka mata, Anda akan berada di sini, tapi 20 tahun di masa depan.

Beri penjelasan sebanyak mungkin untuk merangsang kreativitas peserta. Akan tetapi, hati-hati jangan sampai memberitahu apa yang mereka lihat di masa depan-yaitu pekerjaan mereka!

Berikut ini adalah naskah yang lain:

Bayangkan Anda telah meninggalkan masyarakat ini. Setelah 20 tahun tanpa berhubungan, Anda kembali dan menemukan bahwa segala hal telah berubah menjadi lebih baik. Anda berjalan mengelilingi dan mengamati masyarakat. Jelaskan (dengan pelan dalam hati Anda) hal apa saja yang berubah menjadi lebih baik: Bagaimana kondisi masyarakatnya? Bagaimana bentuk rumah yang ada? Apakah yang dilakukan orang-orang? Siapa yang mereka lihat? Seperti apa kondisi hutan, tanah, sungai dan sawah? Apa yang berubah? Apa yang tidak berubah?

Tergantung pada kelompok, fasilitator dapat mengubah metodenya. Beberapa pemangku kepentingan mungkin merasa kurang nyaman duduk diam 'melamun', yang lain mungkin tidak tertarik hanya dengan mendengarkan fasilitator. Mungkin satu solusinya dengan mengarahkan kelompok berjalan di lingkungan itu. Hentikan pada titik tertentu di lingkungan itu, seperti di sungai, sumur, jalan, sekolah, area pertanian dan rumah, dan mintalah agar mereka menjelaskan apa yang mereka 'lihat' dalam masa depan yang ideal. Dukung aliran ide secara bebas, dan coba pastikan bahwa setiap orang berperan serta.

Selama langkah ini, peserta memikirkan dan mengekspresikan visi pribadi mereka tentang masa depan. Mintalah peserta untuk menuliskan atau menggambar hal-hal yang tergambar paling jelas dalam visi mereka, karena hal ini akan sangat membantu. Pada langkah berikutnya, peserta akan berbagi visi mereka masing-masing dan saling membandingkan visi mereka.

\section{Langkah 3. Berbagi visi}

Setelah mengembangkan visi pribadi, sekarang waktunya untuk mengajak peserta berbagi ide mereka. Mungkin akan ada banyak persamaan, tapi orang-orang juga akan heran mendengar bahwa visi mereka semua berbeda-beda.

Organisasikan peserta menjadi kelompok yang lebih kecil yang beranggotakan 4-8 orang pada setiap kelompok. Dengan demikian, setiap peserta mempunyai waktu untuk menyajikan visi mereka masing-masing. Kelompok kecil juga membuat suasana yang lebih nyaman untuk berbicara dan berbagi. Perhatikan dinamika setempat untuk memastikan bahwa diskusi produktif dan berjalan terbuka. Beberapa individu mendominasi diskusi, sedangkan yang lain malu-malu. 
Beberapa peserta tidak ingin bekerja sama karena ada konflik. Pada kelompok yang lebih kecil ini, mintalah peserta untuk berbagi visi mereka seperti yang mereka gambar, tulis atau ingat. Semua kelompok boleh menggunakan papan poster besar untuk mengkombinasikan ide mereka agar semua orang dapat ikut serta, sehingga orang yang tidak mampu membaca juga dapat memberikan kontribusinya. Kelompok dapat memilih untuk membuat daftar ide.

Langkah ini dapat juga dilakukan tanpa panduan dari fasilitator, sehingga memungkinkan peserta untuk mengatur diri mereka sendiri dan memutuskan bagaimana mereka akan menyelesaikan tugas. Tunjuk ketua kelompok dan berikan panduan untuk memastikan diskusi kelompok berjalan terbuka dan semua orang mendapat giliran bicara, semua ide dihargai, dan sebagainya.

Langkah 4. Membandingkan visi dan mencapai kesepakatan

Setelah setiap kelompok kecil selesai berbagi visi, semua orang kembali ke tempat kerja. Mintalah setiap kelompok kecil menyajikan hasil kerjanya, menunjukkan semua visi, dengan cara menggambar atau menulis, agar dapat dilihat. Kemudian mintalah semua kelompok untuk mendiskusikan dan membandingkan visinya.

Pertanyaan diskusi meliputi:

- Apa yang paling penting dari setiap visi?

- Hal apa yang umum dalam setiap visi?

- Apa perbedaan di antara semua visi?

- Apa yang paling mengherankan Anda?

Tujuan berikutnya dari langkah ini adalah mencapai persetujuan visi bersama tentang masa depan. Setiap individu boleh tidak setuju, tapi harus ada kepentingan bersama yang cukup mewakili sehingga peserta dapat menyetujui bahwa visi bersama tersebut mencerminkan pandangan mereka. Diskusikan apakah visi tersebut telah lengkap dan mewakili masyarakat.
Kotak 38. Menggunakan pembentukan visi untuk memprioritaskan proyek pembangunan di Bolivia

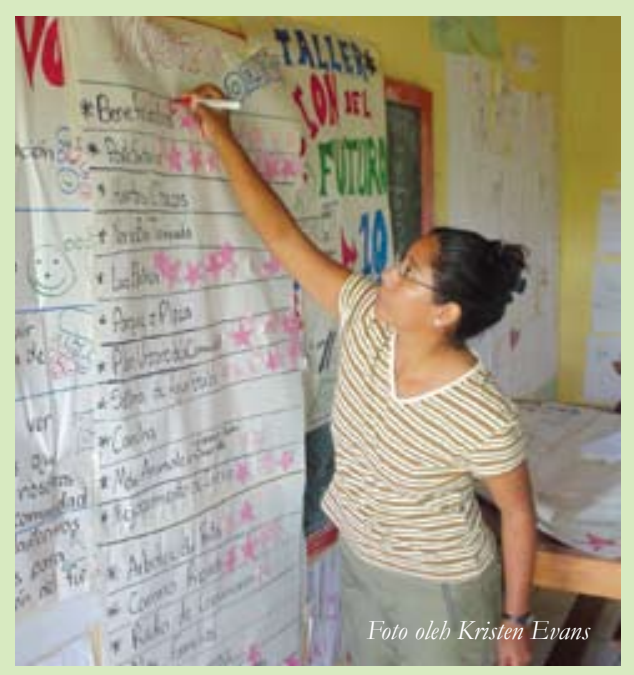

Masyarakat di Pando, Bolivia, menggunakan metode pungut suara untuk menentukan proyek mana yang mereka inginkan dalam proses perencanaan kota tahunan. Pertama, anggota masyarakat melakukan latihan pembentukan visi dalam kelompok kecil. Selanjutnya, masing-masing kelompok berbagi visi mereka. Petugas pencatat mencatat aspek-aspek visi pada flipchart saat aspek-aspek visi disajikan. Kemudian, setiap anggota masyarakat melakukan pungut suara untuk memilih empat aspek yang paling penting bagi masing-masing. Hasil pemungutan suara dijumlahkan, kemudian aspek-aspek dengan hasil suara tertinggi diidentifikasi. Contohnya, air bersih, radio komunikasi dan bangunan sekolah yang lebih baik adalah gagasan umum. Anggota masyarakat kemudian diberi penjelasan tentang cara mencapai visi-visi tersebut dan cara pemerintah daerah berperan serta dalam membantu mereka. Proyek yang terkait kemudian disajikan kepada pemerintah daerah untuk mendapat persetujuan.. 


\section{Kotak 39. Pembentukan visi dalam proses perencanaan partisipatif di Pando}

Kota El Sena di Bolivia menciptakan skenario sebagai alat perencanaan masyarakat. Pertama, 20 orang dan pimpinan masyarakat dari El Sena berpartisipasi dalam seminar pelatihan fasilitator skenario yang disponsori CIFOR. Kemudian, fasilitator yang baru dilatih mengunjungi ke semua 15 komunitas di El Sena untuk memberikan lokakarya skenario. Di setiap masyarakat, semua orang dewasa berpartisipasi dengan antusias.

Selama lokakarya, peserta pertama-tama membayangkan masa depan yang ideal untuk setiap masyarakat, kemudian mereka menggambar atau menuliskan visi mereka dan mendiskusikannya dalam kelompok. Akhirnya, mereka memungut suara untuk menentukan aspek terpenting dari visi mereka. Pada penghujung lokakarya, setiap masyarakat menyajikan daftar tiga atau empat proyek pada pertemuan anggaran pemerintah daerah.

Setelah lokakarya, pimpinan masyarakat berkumpul di balai kota dan saling menyajikan hasil latihan pembentukan visi mereka. Pimpinan masyarakat mendiskusikan visi masyarakat mereka kemudian bekerja sama untuk mengoordinasikan rencana untuk memaksimalkan proyek dan layanan. Contoh, jika dua masyarakat bertetangga keduanya menginginkan pos fasilitas kesehatan, para pimpinan masyarakat berkoordinasi untuk meminta satu pos kesehatan untuk melayani kedua masyarakat, sehingga dana yang ada bisa digunakan untuk membangun sumur air. Kemudian, selama pertemuan perencanaan anggaran dengan walikota dan dewan kota, pimpinan masyarakat menyajikan usulan mereka dan berunding untuk mendapat persetujuan. Kemudian, selama proses peninjauan anggaran akhir tahun, pimpinan dan anggota masyarakat kembali ke visi mereka untuk mengevaluasi pencapaian tujuan mereka.

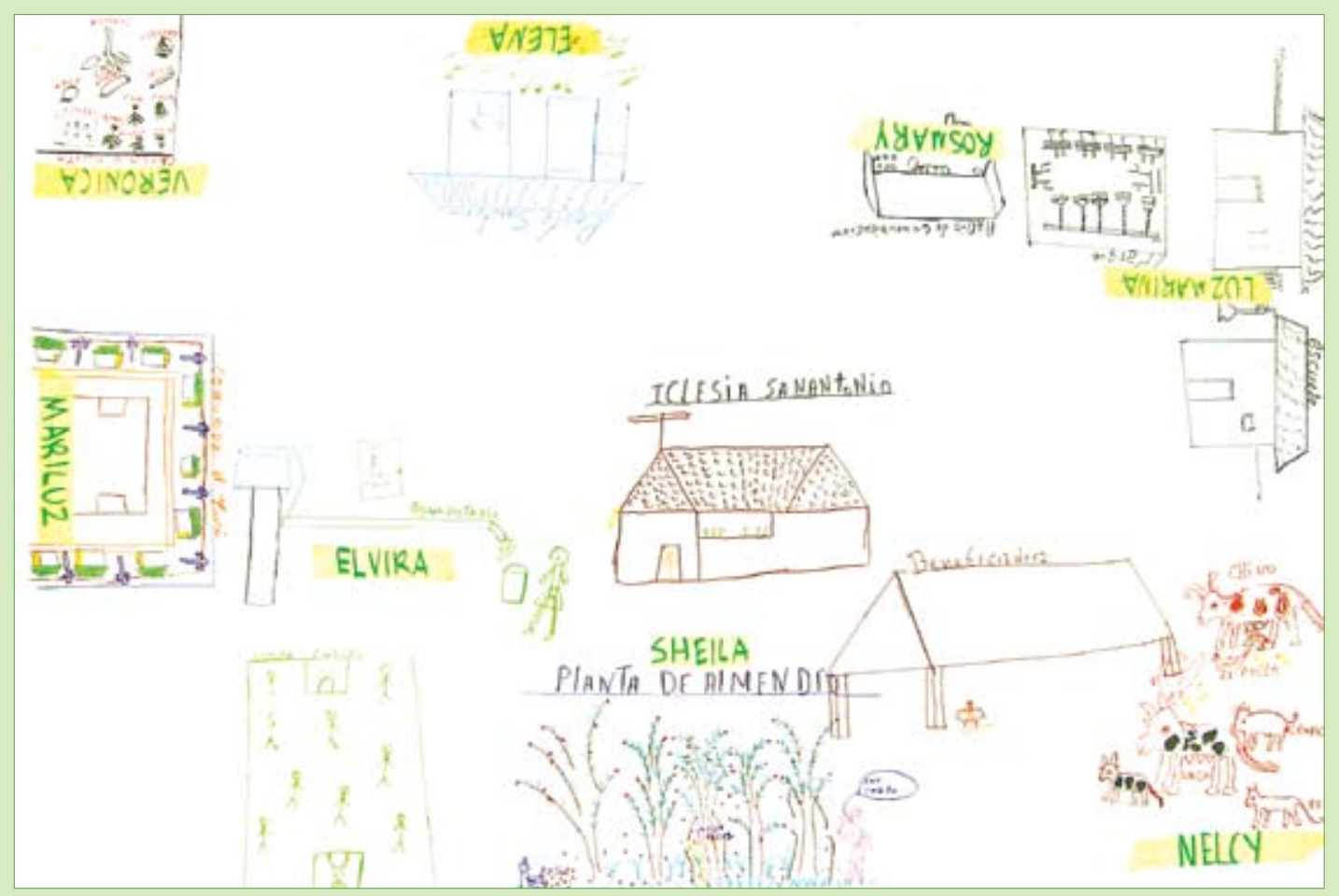

Gambar 21. Visi pembangunan anggota masyarakat di El Sena. 
Pertanyaan diskusi meliputi:

- Apakah ini ide paling penting untuk masyarakat?

- Apakah ada yang terlewat?

- Apakah ada pendapat yang tidak ditampung di sini?

- Bagaimana Anda menggunakan ide-ide untuk perencanaan?

Sebagai langkah pilihan, masyarakat mungkin ingin menentukan prioritas untuk rencana tahunan mereka. Jika demikian, setelah diskusi kelompok, mintalah kelompok untuk mengidentifikasi hal-hal utama dari visi mereka dan menempel daftar ide di tembok untuk dilakukan pemungutan suara. Setiap orang menerima simbol untuk mewakili pilihan mereka. Simbol ditempel di sebelah ide atau diletakkan di dalam amplop di sebelah ide yang paling penting bagi pemilih. Hitung hasil suara dan peringkat ide mulai dari hasil pungut suara paling tinggi ke terendah. Aktivitas ini mengharuskan peserta berbagi ide, memahami kepentingan dan visi mereka dengan peserta lain, dan memprioritaskan mereka untuk mencapai konsensus. Aktivitas ini juga memberikan suara yang sama bagi semua peserta.

Kumpulkan hasil dan siapkan untuk disebarkan kepada anggota masyarakat.

\section{Langkah 5. Menyampaikan hasil}

Hasil kegiatan penting untuk disampaikan ke sebanyak mungkin pihak, termasuk anggota masyarakat, pemerintah daerah, dan lembaga setempat.

- Buatlah produk yang dapat menarik perhatian. Produk bisa berupa poster, peta, kartun, atau cerita bergambar. Masukan foto/gambar kegiatan dan peserta. Pertimbangkan untuk menggunakan karya seni daerah dan budaya untuk menyebarkan hasil.
Contohnya, selenggarakan drama atau cerita dimana peserta dapat berbicara tentang masa depan.

- Sampaikan hasil kepada peserta dan anggota masyarakat lainnya. Tunjukan hasil di tempat umum agar semua orang dapat melihat dan mendiskusikannya.

- Selenggarakan pertemuan masyarakat untuk menyajikan hasil perencanaan. Mintalah masyarakat untuk melakukan curah pendapat tentang bagaimana mereka akan menggunakan hasil tersebut.

- Selenggarakan pemaparan sehingga anggota masyarakat menginformasikan hasil perencanaan mereka dengan pemerintah daerah dan masyarakat lain. Undanglah peserta dari luar seperti pemerintah daerah, LSM lingkungan, dan pembangunan masyarakat.

- Rencanakan lokakarya singkat dengan pejabat daerah agar mereka memahami metode ini. Mintalah anggota masyarakat untuk membantu memfasilitasi lokakarya. Dukung dan promosikan diskusi tentang cara menggunakan metode dalam proses perencanaan partisipatif.

- Libatkan media setempat. Sediakan bahan tulisan untuk pers. Usulkan agar peserta membicarakan tentang latihan ini pada acara radio.

Pembentukan visi dapat diulangi pada skala yang lebih luas (seperti di tingkat regional). Untuk hal ini, perwakilan dari berbagai masyarakat atau sektor pemerintah berkumpul untuk berbagi visi yang telah dibuat sebelumnya oleh kelompok mereka masing-masing. Kemudian mereka bekerja sama untuk menghasilkan visi untuk seluruh wilayah. Cara ini dapat membantu mengkoordinasikan perencanaan pada skala yang lebih luas. 


\section{Jalur}

Setelah masyarakat selesai mengidentifikasi tujuan yang mereka inginkan untuk dicapai melalui pembentukan visi, masyarakat dapat merencanakan tindakan yang dapat membantu mereka untuk tujuan mereka. Dengan kata lain, masyarakat membangun jalur dari masa sekarang hingga masa depan. Dengan mengembangkan jalur, masyarakat akan memiliki struktur perencanaan untuk mencapai tujuan mereka secara bertahap. Struktur tersebut disajikan dalam bentuk rencana tertulis yang menjelaskan langkah dan tanggung jawab tertentu untuk mencapai tujuan. Rencana dapat dipantau sehingga perkembangan pencapaian visi bersama dapat dinilai.

Pertama, peserta bercermin pada situasi saat ini dan membandingkannya dengan situasi yang mereka inginkan di masa depan. Kemudian mereka mengidentifikasi langkahlangkah tertentu yang diperlukan untuk mencapai tujuan masa depan. Setiap langkah secara rinci menetapkan tanggal sasaran

\section{Kotak 40. Saran dan pilihan}

- Pertama, ambil satu contoh untuk menunjukkan langkah kepada semua kelompok. Kemudian bagi peserta menjadi beberapa kelompok dan berikan satu atau dua tujuan kepada masing-masing kelompok untuk menerapkan langkah Jalur.

- Proses ini dapat disesuaikan dengan kelompok yang lebih berpengalaman dalam perencanaan dan memahami teknologi, tapi konsepnya tetap sama, yaitu membuat rencana dengan tanggal dan tanggung jawab terperinci yang dapat dipantau untuk ditindaklanjuti. untuk penyelesaian dan orang yang bertanggung jawab untuk mewujudkannya.

Metode ini membantu masyarakat menguraikan masalah yang lebih besar menjadi beberapa tahap yang lebih kecil. Metode ini memberikan kesempatan bagi masyarakat untuk mengidentifikasi tindakan yang dapat mereka ambil sendiri dan tahap apa yang sekiranya memerlukan bantuan dari pemerintah daerah. Pimpinan masyarakat kemudian dapat menjelaskan tentang kebutuhan warganya dan memberi alasan bagi permohonan bantuan dengan lebih baik. Metode ini membantu pemerintah daerah dalam mengidentifikasi komitmen masyarakat dan dalam memanfaatkan sumber daya daerah dengan lebih baik.

Jalur juga meningkatkan rasa memiliki dan tanggung jawab anggota masyarakat atas suatu rencana. Karena individu tertentu ditunjuk untuk bertanggung atas beberapa langkah dan memenuhi batas waktu penyelesaian tahapan, anggota masyarakat mempunyai informasi penting dalam memantau pelaksanaan dari rencana tersebut.

\section{Langkah 1. Membahas visi dan menganalisa} situasi sekarang

Bandingkan visi masa depan yang ideal dari peserta dengan situasi sekarang untuk mengidentifikasi perbedaan di antara kedua situasi tersebut.

Mintalah peserta untuk memilih tiga atau empat tujuan yang ingin mereka capai, berdasarkan pada visi mereka. Jika visinya adalah jangka panjang, seperti 20 tahun, maka lebih baik membagi jangka waktu tersebut menjadi beberapa jangka waktu yang lebih pendek, seperti lima tahun. Pembagian waktu ini akan membantu agar tujuan menjadi lebih realistis dan membantu agar lebih mudah dalam memikirkan cara mencapai tujuan tersebut.

Selanjutnya, untuk setiap tujuan, mintalah peserta untuk mengidentifikasi apa yang mereka miliki untuk mengubah keadaan masa sekarang untuk mencapai tujuan yang mereka 
inginkan. Hal ini dapat dilakukan dengan pertanyaan sebagai berikut:

- Apa perbedaan antara realitas masa sekarang dengan tujuan masa depan?

- Apa yang tidak ada (kurang) dari masa sekarang?

- Apa halangan yang menghambat untuk pencapaian tujuan mereka?

Mintalah peserta menganalisa keterampilan, sumber daya, atau peluang yang telah mereka miliki guna mencapai tujuan mereka:

- Apakah mereka mempunyai kemampuan atau keterampilan yang dibutuhkan?

- Apakah mereka mempunyai sumber daya atau hak yang dapat mereka jadikan pengungkit?

- Apakah ada kemitraan dengan masyarakat atau lembaga lain yang dapat dikembangkan?

\section{Langkah 2. Mengembangkan strategi untuk} mencapai sasaran

Untuk setiap halangan, peserta membuat strategi untuk memecahkan masalah dan mencapai tujuan mereka. Strategi tersebut meliputi keputusan tentang 'bagaimana, siapa dan kapan' dalam pemecahan masalah. Upayakan agar tanggal dan tanggung jawab tersaji serinci mungkin. Jika strateginya jelas, maka akan lebih mudah bagi masyarakat untuk memantau secara berkelanjutan (lihat Kotak 42).

Mintalah peserta bekerja dalam kelompok dan setiap kelompok ditugasi untuk membuat satu strategi. Jika ini adalah pertama kalinya peserta terlibat dalam jenis perencanaan kelompok, mereka mungkin akan heran bahwa mereka bisa mendapatkan solusi dan keputusan dengan cepat.

\section{Langkah 3. Membahas strategi}

Kumpulkan semua kelompok kecil dan mintalah masingmasing untuk menyajikan strategi mereka. Analisa dan diskusikan bersama dengan memberikan ruang bagi penyesuaian. Sarankan langkah-langkah untuk memantau perkembangan strategi.

Pertanyaan diskusi meliputi:

- Apakah strategi ini masuk akal?

- Apa halangan terbesar atau kemungkinan kegagalan dalam strategi?

- Apakah strategi dapat diperbaiki?

- Apakah pihak luar harus dilibatkan dalam proses ini?

- Bagaimana Anda memastikan bahwa orang yang diberi tugas dapat menyelesaikannya?

- Kapan perkembangan dari strategi ini akan dievaluasi? Siapa yang bertanggung jawab melakukan evaluasi?

- Apakah Anda dapat melakukan ini sekarang tanpa fasilitator?

\section{Kotak 41. Waktu dan bahan untuk jalur}

- 3 jam untuk lokakarya

- Flipchart, alat tulis, plakban.

\section{Tim dan peserta}

- 2 fasilitator

- 1 pencatat (bisa dari masyarakat)

- 15-25 peserta dewasa. 


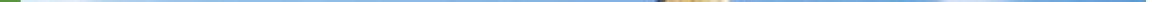

Langkah 4. Menerapkan dan memantau

Ciptakan suatu rencana pemantauan dasar untuk memastikan bahwa strategi dilaksanakan. Rencana harus menyertakan tindakan tertentu untuk menindaklanjuti strategi, seperti rapat dengan peserta untuk mengukur perkembangan.

Sekarang, mulailah melaksanakan strategi!

Perencanaan berbasis

skenario membantu

masyarakat membayangkan

kemungkinan hasil di masa

depan dan dampak jangka

panjang.

buku panduan untuk pemerintah daerah | 93 


\begin{tabular}{|c|c|c|c|c|}
\hline Sekarang & \multicolumn{3}{|c|}{ Strategi } & $\begin{array}{l}\text { Masa } \\
\text { Datang }\end{array}$ \\
\hline \multirow{2}{*}{$\begin{array}{l}\text { Keunggulan atau sumber daya apa yang } \\
\text { kita miliki dan dapat kita gunakan sebagai } \\
\text { pengungkit? } \\
\text { - Sumur air yang baru selesai sebagian } \\
\text { - Buruh kasar } \\
\text { - Pengrajin terampil } \\
\text { - Kayu } \\
\text { Apa kekurangan kita dan halangan apa yang } \\
\text { harus kita atasi untuk mencapai tujuan kita? }\end{array}$} & $\begin{array}{l}\text { Bagaimana kita } \\
\text { mengubahnya? }\end{array}$ & $\begin{array}{l}\text { Siapakah yang } \\
\text { melakukannya? }\end{array}$ & $\begin{array}{l}\text { Kapankah } \\
\text { akan } \\
\text { dilakukan? }\end{array}$ & $\begin{array}{l}\text {...Tujuan masa } \\
\text { depan dicapai!! }\end{array}$ \\
\hline & $\begin{array}{l}\text { Pertama, } \\
\text { memohon } \\
\text { agar walikota } \\
\text { membantu } \\
\text { menyelesaikan } \\
\text { sumur }\end{array}$ & $\begin{array}{l}\text { Komisi dari } \\
\text { masyarakat }\end{array}$ & April & \multirow[t]{6}{*}{$\begin{array}{l}\text { Sumur air yang } \\
\text { selesai dibuat, } \\
\text { bersih dan } \\
\text { selalu terisi air } \\
\text { penuh }\end{array}$} \\
\hline \multirow{5}{*}{$\begin{array}{l}\text { - Sumur air yang tertutup potongan kayu, berisi } \\
\text { katak dan lumpur yang mengering pada musim } \\
\text { kemarau } \\
\text { - Lapisan sumur } \\
\text { - Tembok sumur } \\
\text { - Tutup sumur } \\
\text { - Bahan: batang besi, bata, ember, tali, semen, } \\
\text { kerekan, pasir } \\
\text { - Transportasi untuk bahan } \\
\text { - Uang: total sekitar tiga juta rupiah, } \\
\text { - Sekitar satu juta enam ratus ribu Rupiah } \\
\text { untuk bahan } \\
\text { - Sekitar satu juta tiga ratus ribu Rupiah } \\
\text { untuk menyewa truk dari kota untuk } \\
\text { membawa bahan } \\
\text { - Sekitar } 130 \text { ribu rupiah untuk menyewa } \\
\text { truk dari masyarakat sebelah untuk } \\
\text { membawa pasir }\end{array}$} & $\begin{array}{l}\text { Mengumpulkan } \\
\text { satu setengah } \\
\text { kotak dari jumlah } \\
\text { panen kacang } \\
\text { Brazil yang } \\
\text { disumbangkan per } \\
\text { keluarga }\end{array}$ & $\begin{array}{l}\text { Claudia Bendahara } \\
\text { masyarakat }\end{array}$ & Maret & \\
\hline & Membeli bahan & $\begin{array}{l}\text { Claudia, Bendahara, } \\
\text { pengrajin } \\
\text { dan pimpinan } \\
\text { masyarakat }\end{array}$ & Awal April & \\
\hline & Membeli semen & Claudia dan Guido & September & \\
\hline & & & & \\
\hline & $\begin{array}{l}\text { Menggali sumur } \\
\text { lebih dalam, } \\
\text { membersihkannya }\end{array}$ & $\begin{array}{l}\text { Pengrajin Guido } \\
\text { dan relawan dari } \\
\text { masyarakat }\end{array}$ & September & \\
\hline
\end{tabular}




\section{Kotak 43. Saran untuk memulai}

Perencanaan berbasis skenario bersifat partisipatif dan berdaya guna. Akan tetapi, mungkin sulit untuk meyakinkan masyarakat tentang keefektifan perencanaan berbasis skenario jika mereka tidak mencobanya. Dengan demikian, cara terbaik untuk menyampaikan kepada pejabat pemerintah daerah dan masyarakat tentang maksud perencanaan berbasis skenario dan menunjukkan bagaimana perencanaan ini dapat membantu mereka adalah dengan memberi contoh melalui tindakan'

- Selenggarakan lokakarya Skenario dengan pejabat pemerintah daerah dan pimpinan masyarakat. Dalam lokakarya ini, mereka berpartisipasi dalam proses Skenario yang sebenarnya. Lokakarya ini harus merupakan proses perencanaan nyata, bukan sekadar situasi hipotesis. Selama dan setelah latihan, diskusikan cara menggunakan skenario untuk perencanaan partisipatif dalam masyarakat. Apakah metode perlu disesuaikan? Apakah bisa dilakukan pada semua masyarakat? Siapa yang dapat mendampingi dan memandu?

- Pandu dan fasilitasi lokakarya Skenario dalam satu kelompok masyarakat. Setelah lokakarya, lakukan pemaparan hasil oleh para peserta agar mereka dapat menyampaikan hasilnya kepada kelompok masyarakat lain dan menjelaskan metodenya.

- Rencanakan sesi pelatihan fasilitator daerah dalam metode Skenario. Undang calon fasilitator, seperti pejabat pemerintah daerah, ketua organisasi masyarakat, dan guru. Langkah ini akan membentuk tim fasilitator Skenario yang dapat menyelenggarakan lokakarya dalam berbagai kelompok masyarakat.

Untuk informasi lebih lanjut tentang perencanaan berbasis skenario, silakan mengacu pada:

Wollenberg, E., Edmunds, D. and Buck, L. 2000

Anticipating change: Scenarios as a tool for adaptive forest management: A guide. CIFOR, Bogor, Indonesia.

Evans, K., Velarde, S.J., Prieto, R.P., Rao, S.N., Sertzen, S., Davila, K., Cronkleton, P. and de Jong, W. 2006 Field guide to the future: Four ways for communities to think ahead. Alternatives to Slash and Burn Consortium, World Agroforestry Centre, Nairobi, Kenya. (Available at: www.asb.cgiar.org/ma/scenarios)

Nemarundwe, N., de Jong, W. and Cronkleton, P. 2003 Future scenarios as an instrument for forest management. CIFOR, Bogor, Indonesia.

Peterson, G.D., Beard, T.D., Beisner, B.E., Bennett, E.M., Carpenter, S.R., Cumming, G.S., Dent, C.L. and Havlicek, T.D. 2003 Assessing future ecosystem services: a case study of the Northern Highlands Lake District, Wisconsin. Conservation Ecology 7(3): Article 1. (http:/ www.ecologyandsociety.org/vol 7/iss3/art1/print.pdf) 


\section{Ucapan Terimakasih}

Di Bolivia, kami ucapkan terimakasih kepada semua warga dan pejabat di Kotamadya El Sena yang telah berpartisipasi dalam proyek penelitian ini. Mereka membimbing dan berbagi informasi dengan kami, dan juga menjadi mitra yang antusias dan ringan tangan dalam semua aktivitas, lokakarya, pertemuan dan kerja lapangan selama beberapa tahun terakhir. Secara khusus ucapan terimakasih kami sampaikan kepada Pemerintah Kotamadya El Sena dan Walikota Napoleon Antelo yang telah mendukung proyek ini dan memberikan sumber dayanya untuk membantu kami dalam banyak hal. Secara khusus pula, kami ucapkan terimakasih kepada anggota Pemerintah El Sena dan penduduk berikut ini: Walter Roca, Luís Lazo, Dionisio Huallas, Walter Huarena, Rodilid Salvatierra, Sonia Vidaurre, Mariano Justiniano, Hugo Zabala, Remberto Forero, Juan Lazo, Félix Patzi, Yasmani Zabala, Emilio Cambero, Moisés Tuno, Onofre Siviora, Jhonny Justiniano, Lady Laura Salvatierra dan Florinda Vaca. Kami juga harus mengucapkan terimakasih kepada lembaga-lembaga setempat, seperti Prefecture of Pando, Association of Municipal Governments of Pando (AMDEPANDO), Bolivian Forest Superintendence dan Fundación José Manuel Pando. Ucapan terimakasih juga untuk sejumlah mahasiswa yang melakukan proyek penelitian individu yang berkontribusi bagi kerja kami: Jennifer Kleeb, Meike Steimann, Lígia Pereira and Claudia Oemer.

Di Indonesia, kami ucapkan terimakasih kepada masyarakat dan pemerintah daerah Malinau dan Kutai Barat serta lebih dari 200 orang pendata desa atas kerjasamanya yang baik. Pemerintah Kabupaten Kutai Barat telah menanggung semua biaya untuk survei kesejahteraan tahun 2006. Secara khusus, untuk kegiatan di Kutai Barat kami ucapkan terimakasih kepada Rama A. Asia, Encik Mugnidin, Silas Sinan, Fredrick Ellia, Yuvinus Nyintih, Fincen Allotodang, Asrani, Subhan Noor, Sangga Sarira, Firdaus, Abimael, Elivianus, Edi Almudin, Erwin Dani, Eli Surario, Rudi Warjono, Jakaria, Darius Dalip, Kukuh Tugiyono, Doni Tiaka, Brigita Edna, Maria Goretti Dau, Berry Iranon, Harifuddin, Muksin, Supiansyah, Yohanes, Mikael Meksis, Yosep Darius, Wehang, Benyamin, Y. Njuk Hanyeq, Mikael Deng, David Erison, Rusandi, Mikael Muis, Y. Silam Ajang, Arlis, Markus, Hang Huvang, Junaidi, Wilhelmus, Yansen Toding Datu, Tusin, Arminsyah Sumardi, Ham Wilhelmus, Ruth Aktalia, Priyana, Rustam, Imanuel, Istanto, Gung Usat, Ami Paramban, Nanda Pratama, Rikardo, Ahmad, Yosep Suparno, Yance, Edy, Victor Yosafat, Nuryani, Waina, Brigita Edna, Cathrin Bullinger, Erna Rositah, Benyamin, Oding Affandi, Agus Andrianto dan Bison.

Secara khusus, untuk kegiatan di Malinau kami ucapkan terimakasih kepada Marthin Billa, Encik Muh. Yunus (alm.), Jansen TP, Djalung Merang, Yermia Bumbu (alm.), Jusuf Rapa, Sudarsono, Saparuddin, S. Manullang, Andarias Padan, Karmani, Yonathan Yahuda, Armansyah, Mathias Henry, Sole Liang, Aan Hartono, Fadliansyah, Dollop Mamung, Dody Hernawan, Abdon Ucan, Adau Ipu, Sumiati Njau, Yurita Bid, Luhat Adjang, Sarkawi, Dorthy Buing, Marten Dermawan, Dhani Subroto, Ahmad Chari Syafaadi, Iksan Hadi, Kasransyah, Antonius Mangiwa, Taufiq, Agustinus Are, Lengkan Baya dan Bayu 
Kami berterimakasih kepada para peserta pertemuan ahli internasional di Maurach, Lake Constance (Jerman) pada bulan Mei 2006, antara lain Hans Aeppli, Borany Penh, Judith Schlehe, Brian Belcher, Thomas Sikor, Erlinda Montillo-Burton, Rosalie McConnell, John-Andrew McNeish, Everisto Mapedza, Marco Antonio Núñez del Prado Coll, Pablo Pacheco dan Martin Tampe, atas masukan berharga mereka dalam eksplorasi kita bersama untuk mempelajari kaitan desentralisasi, hutan dan kemiskinan.

Di University of Freiburg, kami berterimakasih kepada Michel Becker dan Stefan Seitz atas bimbingannya terhadap para mahasiswa dan petunjuknya yang bernilai selama seluruh proyek ini. Carol Grossmann telah membantu mengawali proyek ini dari permulaan.

Di GTZ Indonesia, kami berterimakasih kepada Manfred Poppe dan Bernhard May atas kerjasamanya yang sangat baik, serta tim ProBangkit, khususnya Roto Priyono.

Kami juga berterimakasih kepada Friedhelm Betke dari CIM/ BPS yang telah berbagi gagasan inovatif dengan proyek ini tentang kemiskinan.

Di CIFOR, ucapan terimakasih kami sampaikan untuk Rita Rahmawati, Dina Hubudin, Charlotte Soeria, Doris Capistrano, Sonya Dewi, Brian Belcher, Gideon Suharyanto, Atie Puntodewo dan Christine Wulandari.

Di BMZ/BEAF, kami berterimakasih kepada Stefan Krall, Michael Bosch dan Iris Schubert.

Untuk Carol J. Pierce Colfer, Betsy Campbell dan Borany Penh yang dengan cermat telah meninjau draf awal Buku Panduan ini dan memberi komentar dan masukan yang sangat berharga untuk perbaikannya, kami juga mengucapkan terimakasih. 


\section{Catatan Akhir}

Membantu masyarakat agar terlepas dari kemiskinan adalah salah satu fungsi utama pemerintah daerah. Melibatkan masyarakat dalam pengambilan keputusan yang mempengaruhi kesejahteraannya adalah langkah pertama yang harus dilakukan.

Kami memahami bahwa tidak mudah untuk mengubah pelaksanaan suatu hal di tingkat pemerintah daerah. Perubahan ini merupakan proses yang memerlukan komitmen sejati untuk direformasi, dan hal ini memerlukan waktu lama. Namun demikian kami berharap konsep dan alat yang ditawarkan dalam buku panduan ini dapat memberi ide-ide praktis dan inspirasi agar proses tersebut dapat segera dimulai.

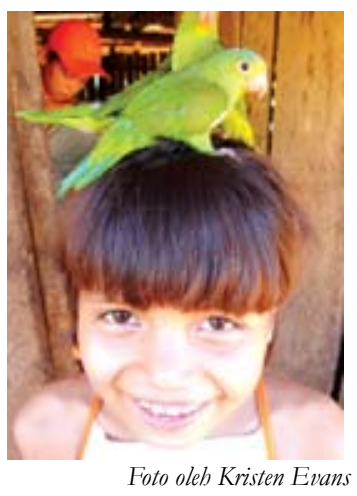


Center for International Forestry Research (CIFOR) adalah lembaga penelitian kehutanan internasional terdepan, yang didirikan pada tahun 1993 sebagai tanggapan atas keprihatinan dunia akan konsekuensi sosial, lingkungan dan ekonomi yang disebabkan oleh kerusakan dan kehilangan hutan. Penelitian CIFOR ditujukan untuk menghasilkan kebijakan dan teknologi untuk pemanfaatan dan pengelolaan hutan yang berkelanjutan, dan untuk meningkatkan kesejahteraan masyarakat di negara-negara berkembang yang bergantung kepada hutan tropis untuk kehidupannya. CIFOR adalah salah satu di antara 15 pusat di bawah Consultative Group on International Agricultural Research (CGIAR). Berpusat di Bogor, Indonesia, CIFOR mempunyai kantor regional di Brazil, Burkina Faso, Kamerun dan Zimbabwe, dan bekerja di lebih dari 30 negara di seluruh dunia.

Donatur

CIFOR menerima pendanaan dari pemerintah, organisasi pembangunan internasional, yayasan swasta dan organisasi regional. Pada tahun 2006, CIFOR menerima bantuan keuangan dari Australia, Asian Development Bank (ADB), African Wildlife Foundation, Belgium, Canada, Carrefour, Cecoforma, China, Centre de coopération internationale en recherche agronomique pour le développement (CIRAD), Convention on Biological Diversity, Cordaid, Conservation International Foundation (CIF), European Commission, Finland, Food and Agriculture Organization of the United Nations (FAO), Ford Foundation, France, German Agency for Technical Cooperation (GTZ), German Federal Ministry for Economic Cooperation and Development (BMZ), German Foundation for International Cooperation, Global Forest Watch, Indonesia, Innovative Resource Management (IRM), International Institute for Environment and Development, International Development Research Centre (IDRC), International Fund for Agricultural Development (IFAD), International Tropical Timber Organization (ITTO), Israel, Italy, the World Conservation Union (IUCN), Japan, Korea, MacArthur Foundation, Netherlands, Norway, Netherlands Development Organization, Overseas Development Institute (ODI), Peruvian Secretariat for International Cooperation (RSCl), Philippines, Spain, Sweden, Swedish University of Agricultural Sciences (SLU), Switzerland, The Overbrook Foundation, The Tinker Foundation Incorporated, The Nature Conservancy (TNC), Tropical Forest Foundation, Tropenbos International, United States, United Kingdom, United Nations Environment Programme (UNEP), United Nations Educational, Scientific and Cultural Organization (UNESCO), United Nations Forum on Forests (UNFF), Wageningen International, World Bank, World Resources Institute (WRI) dan World Wide Fund for Nature (WWF). 
Pemerintah di sejumlah negara menerapkan desentralisasi untuk lebih memberikan wewenang atas pengambilan keputusan dan anggaran kepada pemerintah daerah.Salah satu harapan atas perubahan ini adalah pemerintah daerah akan lebih efektif dan efisien dalam menanggapi kebutuhan penduduk termiskin di daerahnya. Desentralisasi sangat penting bagi masyarakat yang tinggal di dalam dan sekitar hutan. Khususnya karena sejak lama mereka mendapatkan sedikit sekali manfaat dari pelayanan pemerintah dan program penanggulangan kemiskinan karena kondisi fisiknya yang terpisah dan terpinggirkan secara sosial.

Buku Panduan ini ditulis untuk pemerintah daerah dan mitranya yang ingin tanggap terhadap kebutuhan masyarakat hutan dan meningkatkan kesejahteraan rakyatnya. Buku ini di awal membahas konsep-konsep penting, seperti desentralisasi, kesejahteraan, kemiskinan, dan hubungan antara hutan dan kemiskinan. Berikutnya Buku Panduan ini menyajikan empat alat partisipatif yang memungkinkan pemerintah daerah untuk melibatkan masyarakat yang tinggal di dalam dan sekitar hutan dalam perencanaan, pemantauan, dan evaluasi pembangunan dan program penanggulangan kemiskinan, yaitu: memantaukonteks kemiskinan setempatmelalui pemetaan interaktif; memantau kesejahteraan rumah tangga melalui indikator setempat; evaluasi masyarakat terhadap program pemerintah daerah melalui kelompok fokus; dan menyampaikan kebutuhan masyarakat melalui perencanaan berbasis skenario.

Buku Panduan ini didasarkan pada hasil proyek penelitian aksi yang dilaksanakan di masyarakat hutan di Indonesia dan Bolivia oleh Center for International Forestry Research (CIFOR). Meskipun hanya dikembangkan dan diuji di dua negara, konsep dan alat dalam Buku Panduan ini dapat diterapkan bagi masyarakat dan pemerintah di seluruh dunia.

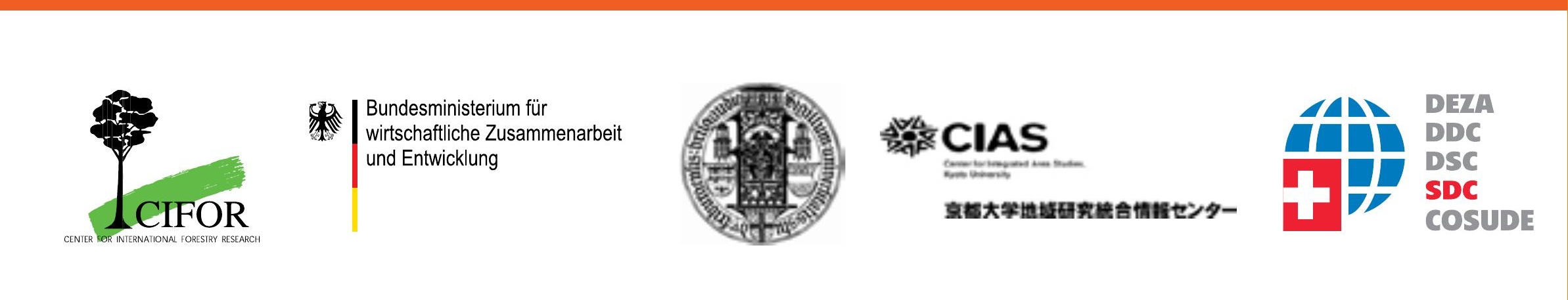

